Key Words:

TMDL

Water Quality

Fish

Air Deposition

\title{
Final Report on the Aquatic Mercury Assessment Study
}

\author{
N.V. Halverson \\ J.A. Bowers \\ M.H. Paller \\ D.G. Jackson \\ J.K. King \\ D.L. Dunn
}

September 2008

Savannah River National Laboratory

Savannah River Nuclear Solutions

Aiken, SC 29808

Prepared for the U.S. Department of Energy Under

Contract Number DE-AC09-08SR22470

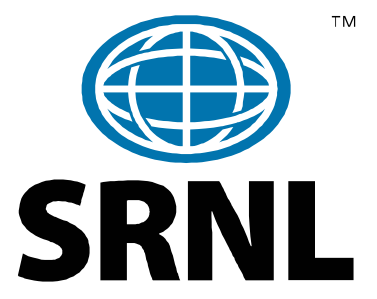




\section{DISCLAIMER}

This work was prepared under an agreement with and funded by the U.S. Government. Neither the U. S. Government or its employees, nor any of its contractors, subcontractors or their employees, makes any express or implied:

1. warranty or assumes any legal liability for the accuracy, completeness, or for the use or results of such use of any information, product, or process disclosed; or

2. representation that such use or results of such use would not infringe privately owned rights; or 3. endorsement or recommendation of any specifically identified commercial product, process, or service. Any views and opinions of authors expressed in this work do not necessarily state or reflect those of the United States Government, or its contractors, or subcontractors.

Printed in the United States of America

Prepared for

U.S. Department of Energy 


\section{Table of Contents}

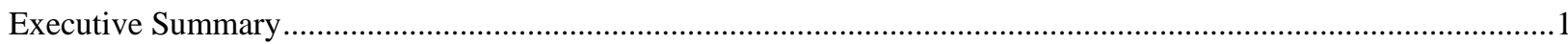

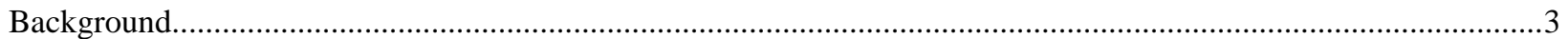

Mercury in Savannah River Site Outfalls, Streams and the Savannah River..............................................................

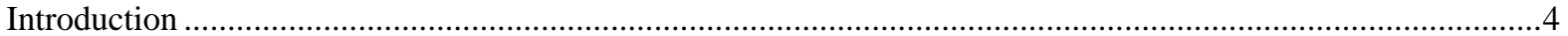

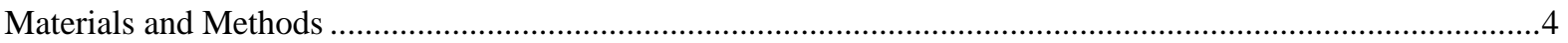

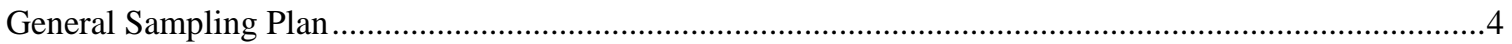

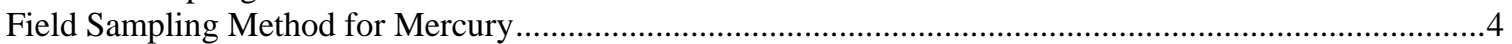

Laboratory Analysis for Total and Methylmercury ..............................................................................

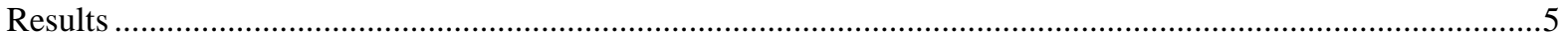

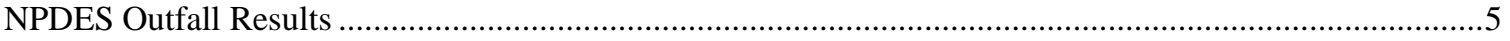

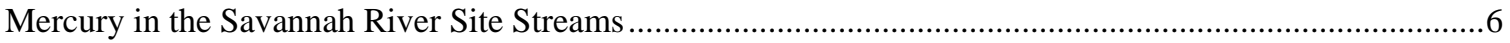

Mercury in the Savannah River .......................................................................................................

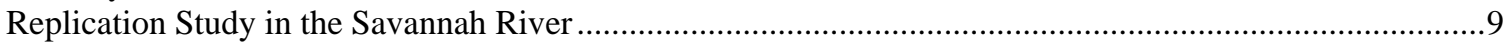

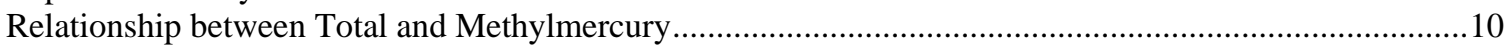

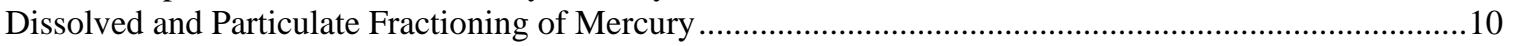

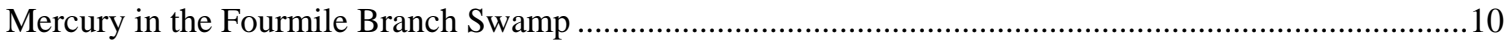

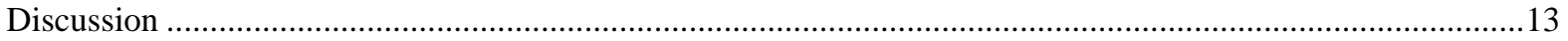

Mercury Bioaccumulation Factors for Savannah River Fish..............................................................................16

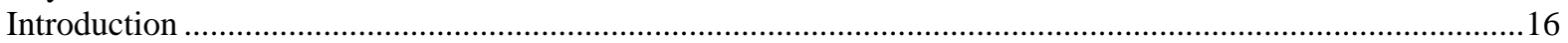

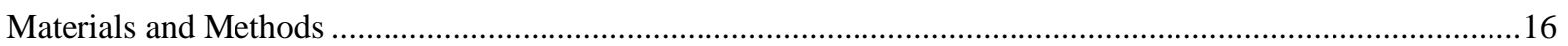

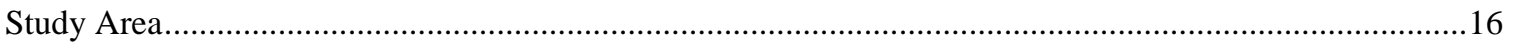

Field and Laboratory Methods ..........................................................................................................18

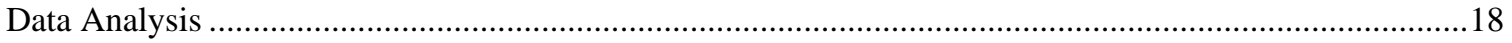

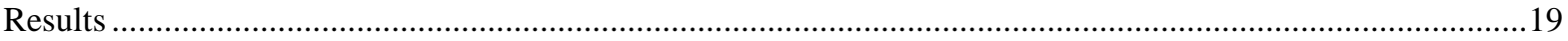

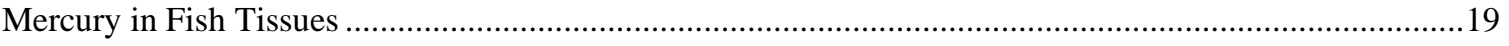

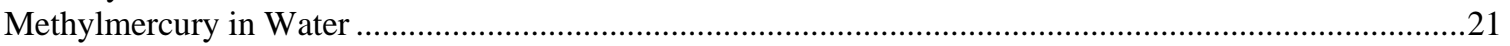

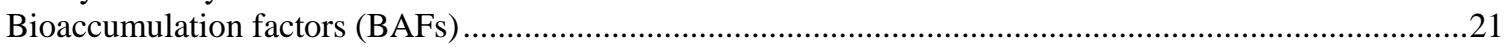

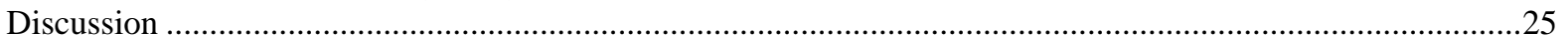

Effects of Tributary Stream Methylmercury on Mercury Levels in Savannah River Asiatic Clams..........................27

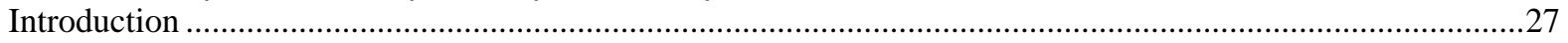

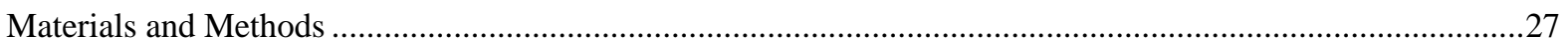

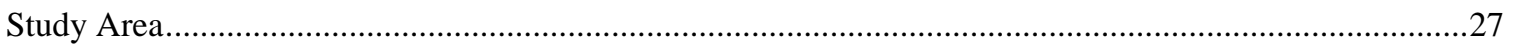

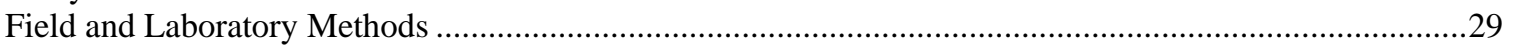

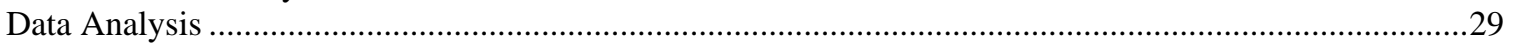

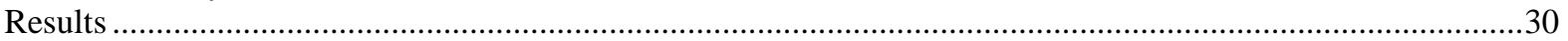

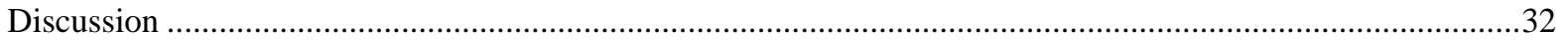

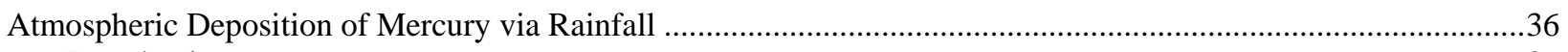

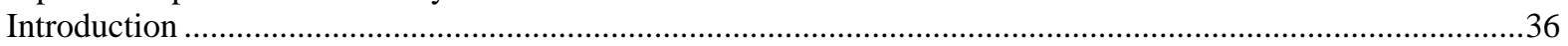

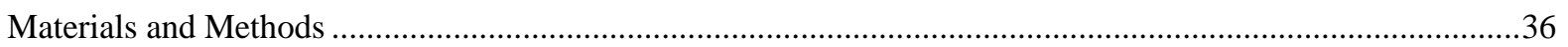

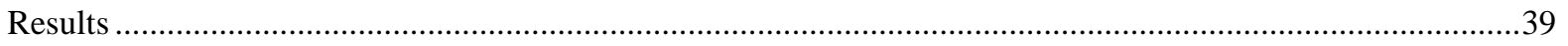

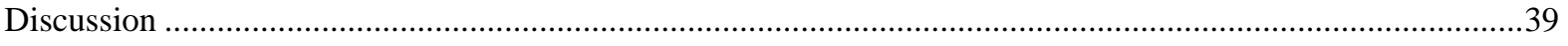

Preliminary Mass Balance of Mercury at the Savannah River Site …….................................................................45

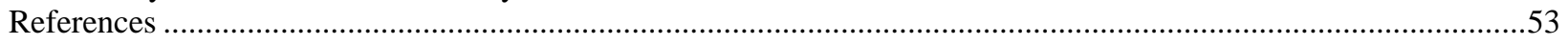

Appendix A. Savannah River Site NPDES Sampling Stations................................................................................60

Appendix B. Savannah River and Stream Sampling Stations at the Savannah River Site. ......................................61

Appendix C. Total Mercury (ng/l) at Savannah River Site NPDES Outfalls. .........................................................62

Appendix D. Total Mercury (ng/l) in Savannah River Site Streams. ........................................................................64

Appendix E. Methylmercury (ng/l) in Savannah River Site Streams. ......................................................................65

Appendix F. Total Mercury (ng/l) in the Savannah River......................................................................................66

Appendix G. Methylmercury (ng/l) in the Savannah River......................................................................................67 


\section{List of Figures}

Figure 1. Relationship between total mercury and methylmercury based on SRS stream and Savannah River

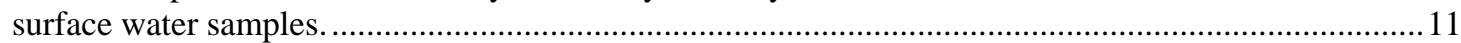

Figure 2. Mean of percent particulate fraction of total and methylmercury at Savannah River stations. ...............12

Figure 3. Map showing Savannah River sample areas from which fish and water were collected for mercury analysis.

Figure 4. Total mercury concentrations in fishes collected from the Savannah River......................................20

Figure 5. Size adjusted (least square) geometric mean total mercury concentrations (95\% confidence intervals) for largemouth bass and sunfishes collected from lower (L), middle (M) and upper (U) locations in the Savannah River during fall 2000 (1), spring 2001 (2), and late summer 2001 (3) ........20

Figure 6. Geometric mean dissolved methylmercury concentrations at different locations and during different seasons in the Savannah River...

Figure 7. Average mercury bioaccumulation factors (95\% confidence intervals) for the lower (L), middle (M) and upper (U) locations in the Savannah River during fall 2000 (1), spring 2001 (2), and late summer 2001 (3).....

Figure 8. Effects of number of fish samples and number of water samples on largemouth bass BAF coefficient of variation (CV).

Figure 9. Relationship between sample size and the 95\% confidence interval (expressed as a percentage of the mean) for largemouth bass bioaccumulation factors (BAFs)......

Figure 10. Map of the middle reaches of the Savannah River showing important tributary streams and the Savannah River Site.

Figure 11. Average aqueous methylmercury and total mercury levels in the Savannah River and the five SRS Savannah River tributary creeks on 11 sample dates.

Figure 12. Average aqueous methylmercury and total mercury levels, and percentages of total mercury that were methylmercury in the Savannah River (SR) and seven streams: Upper Three Runs (UTR), Beaver Dam Creek (BDC), Fourmile Branch (FMB), Steel Creek (SC), Lower Three Runs (LTR), Brier Creek (BC), and Ebenezer Creek (EC).

Figure 13. Relationship between mercury concentration and shell length in Corbicula fluminea collected from the Savannah River and several Savannah River tributaries......

Figure 14. Geometric mean mercury levels in Corbicula fluminea collected from six Savannah River tributaries (Upper Three Runs, UTR; Beaver Dam Creek, BDC; Fourmile Branch, FMB; Steel Creek, SC; Lower Three Runs, LTR; Brier Creek, BC; Ebenezer Creek, EC) and six Savannah River sites located just upstream from each of the tributaries.

Figure 15. Sampling stations in the United States and Canada that constituted the Mercury Deposition Network of the National Atmospheric Deposition Program during this study.

Figure 16. Mercury Deposition Network sampling stations located in Georgia and South Carolina during this study. Station sponsors were the U.S. Fish and Wildlife Service (GA09), The Southern Company (GA40), Westinghouse Savannah River Company (SC03), and South Carolina Division of Air Quality (SC19).

Figure 17. Annual median (solid line), $25^{\text {th }}, 75^{\text {th }}$ quartiles (dashed line) and monthly variation (box \& whiskers) of total mercury concentration in precipitation for the period from January 1996 through December 2002 from NADP MDN stations located in Georgia and South Carolina (Stations GA09, GA40, SC03 and SC19).

Figure 18. Annual median (solid line), $25^{\text {th }}, 75^{\text {th }}$ quartiles (dashed line) and monthly variation (box \& whiskers) of weekly deposition rate of total mercury from precipitation for the period from January 1996 through December 2002 from NADP MDN stations located in Georgia and South Carolina (Stations GA09, GA40, SC03 and SC19).

Figure 19. Mercury mass balance inputs and outputs.

Figure 20. Mercury flux into and out of the SRS Boundary area based on data from June 1999 through September 2002. 


\section{List of Tables}

Table 1. Quantile statistics for total mercury (ng/l) at the SRS-NPDES outfalls for data collected from January 1999 to September 2002........

Table 2. Total mercury concentrations (ng/l) at SRS NPDES outfalls from samples collected from August 1999 through September 2002......

Table 3. Total mercury (ng/l) in SRS streams from samples collected from June 1999 through September 2002.

Table 4. Methylmercury (ng/l) in SRS streams from samples collected from June 1999 through September 2002 .

Table 5. Total mercury (ng/l) in the Savannah River near SRS stream mouths from samples collected from June 1999 through September 2002.

Table 6. Methylmercury (ng/l) in the Savannah River near SRS stream mouths from samples collected from June 1999 through September 2002.

Table 7. Triplicate total mercury (ng/l) concentrations in the Savannah River during April 2001........................9

Table 8. Triplicate methylmercury (ng/l) concentrations in the Savannah River during April 2001.....................10

Table 9. Mean of percent particulate fraction of total and methylmercury at SRS stream and stream mouth stations.

Table 10. Total and methylmercury concentrations from small shallow pools in the Fourmile Branch swamp, Savannah River Site, July 10, 11 and August 1, 2001.

Table 11. Total and methylmercury concentrations in this study compared with other surveys in the southeastern United States.

Table 12. Analytical concentration and deposition results for total and methylmercury for samples collected from November 2001 to January 2003 at Station SC03 as part of the Mercury Deposition Network.....40

Table 13. Summary of concentration and deposition results for total and methylmercury between January 2001 and January 2003 at Station SC03 as part of the Mercury Deposition Network.

Table 14. Summary data of total mercury concentration in precipitation and associated weekly deposition rates from January 1996 through December 2002 at NADP MDN Stations GA09 and SC19................44

Table 15. SRS stream and Savannah River flows used in mercury mass balance calculations .................................47

Table 16. Total mercury flux in site streams and Savannah River using unfiltered data from June 1999 through September 2002.

Table 17. Methylmercury flux in site streams and Savannah River using unfiltered data from June 1999 through September 2002.

Table 18. Mercury loading to surface water from SRS NPDES Outfalls, based on samples collected from August 1999 through September 2002.

\section{List of Acronyms}

$\begin{array}{ll}\text { ANCOVA } & \text { Analysis of Covariance } \\ \text { ANOVA } & \text { Analysis of Variance } \\ \text { BAF } & \text { Bioaccumulation Factor } \\ \text { BC } & \text { Brier Creek } \\ \text { BDC } & \text { Beaver Dam Creek } \\ \text { CI } & \text { Confidence Interval } \\ \text { CV } & \text { Coefficient of Variation } \\ \text { EC } & \text { Ebenezer Creek } \\ \text { EPA } & \text { Environmental Protection Agency } \\ \text { FMB } & \text { Fourmile Branch } \\ \text { LTR } & \text { Lower Three Runs } \\ \text { MDN } & \text { Mercury Deposition Network } \\ \text { NADP } & \text { National Atmospheric Deposition } \\ & \text { Program }\end{array}$

NPDES National Pollutant Discharge Elimination System

RK River Kilometer

RM River Mile

SC Steel Creek

SR Savannah River

SRS Savannah River Site

TMDL Total Maximum Daily Load

USGS United States Geological Survey

UTR Upper Three Runs

WSRC Washington Savannah River Company 


\section{Executive Summary}

In February 2000, the United States Environmental Protection Agency (EPA) Region 4 issued a proposed Total Maximum Daily Load (TMDL) for total mercury in the middle and lower Savannah River. The initial TMDL, which would have imposed a $1 \mathrm{ng} / \mathrm{l}$ mercury limit for discharges to the middle/lower Savannah River, was revised to 2.8 ng/l in the final TMDL released in February 2001. The TMDL was intended to protect people from the consumption of contaminated fish, which is the major route of mercury exposure to humans. The most bioaccumulative form of mercury is methylmercury, which is produced in aquatic environments by the action of microorganisms on inorganic mercury. Because of the environmental and economic significance of the mercury discharge limits that would have been imposed by the TMDL, the Savannah River Site (SRS) initiated several studies concerning: 1) mercury in SRS discharges, SRS streams and the Savannah River, 2) mercury bioaccumulation factors for Savannah River fish, 3) the use of clams to monitor the influence of mercury from tributary streams on biota in the Savannah River, and 4) mercury in rainwater falling on the SRS. The results of these studies are presented in detail in this report.

The first study documented the occurrence, distribution and variation of total and methylmercury at SRS industrial outfalls, principal SRS streams and the Savannah River where it forms the border with the SRS. All of the analyses were performed using the EPA Method 1630/31 ultra low-level and contaminant-free techniques for measuring total and methylmercury. Total mercury at National Pollutant Discharge Elimination System (NPDES) outfalls ranged from 0.31 - $604 \mathrm{ng} / \mathrm{l}$ with a mean of $8.71 \mathrm{ng} / \mathrm{l}$. Mercury-contaminated groundwater was the source for outfalls with significantly elevated mercury concentrations. Total mercury in SRS streams ranged from $0.95-15.7 \mathrm{ng} / \mathrm{l}$. Mean total mercury levels in the streams varied from $2.39 \mathrm{ng} / \mathrm{l}$ in Pen Branch to $5.26 \mathrm{ng} / \mathrm{l}$ in Tims Branch. Methylmercury ranged from $0.002 \mathrm{ng} / \mathrm{l}$ in Upper Three Runs to $2.60 \mathrm{ng} / \mathrm{l}$ in Tims Branch. Total mercury in the Savannah River ranged from $0.62 \mathrm{ng} / \mathrm{l}$ to $43.9 \mathrm{ng} / \mathrm{l}$, and methylmercury ranged from $0.036 \mathrm{ng} / \mathrm{l}$ to $7.54 \mathrm{ng} / \mathrm{l}$. Both total and methylmercury concentrations were consistently high in the river near the mouth of Steel Creek. Total mercury was positively correlated with methylmercury $(r=0.88)$. Total mercury bound to particulates ranged from $41 \%$ to $57 \%$ in the river and from $28 \%$ to $90 \%$ in the streams. Particulate methylmercury varied from $9 \%$ to $37 \%$ in the river and from $6 \%$ to $79 \%$ in the streams. Small temporary pools in the Savannah River swamp area near and around Fourmile Branch had the highest concentrations observed in the Savannah River watershed, reaching 1,890 ng/l for total mercury and $34.0 \mathrm{ng} / \mathrm{l}$ for methylmercury.

The second study developed a mercury bioaccumulation factor (BAF) for the Savannah River near SRS. A BAF is the ratio of the concentration of mercury in fish flesh to the concentration of mercury in the water. BAFs are important in the TMDL process because target concentrations for mercury in water are computed from BAFs. Mercury BAFs are known to differ substantially among fish species, water bodies, and possibly seasons. Knowledge of such variation is needed to determine a BAF that accurately represents average and extreme conditions in the water body under study. Analysis of fish tissue and aqueous methylmercury samples collected at a number of locations and over several seasons in a $110 \mathrm{~km}$ (68 mile) reach of the Savannah River demonstrated that BAFs for each species under study varied by factors of three to eight. Influences on BAF variability were location, habitat and season-related differences in fish mercury levels and seasonal differences in methylmercury levels in the water. Overall (all locations, habitats, and seasons) average BAFs were $3.7 \times 10^{6}$ for largemouth bass, $1.4 \times 10^{6}$ for sunfishes, and $2.5 \times 10^{6}$ for white catfish. This study showed that determination of representative BAFs for large rivers requires the collection of large numbers of fish and aqueous methylmercury samples over at least one complete seasonal cycle from the entire area and all habitats to be represented by the TMDL.

The third study concerned the use of clams as an indicator of the influence of SRS discharges on mercury levels in Savannah River biota. Mercury levels were compared in Asiatic clams (Corbicula fluminea) collected from the discharge plumes and just upstream of the mouths of SRS creeks and two creeks located downstream from the SRS. Asiatic clams were selected for study because their relatively sedentary behavior made them a better indicator of local mercury exposure than mobile organisms. Mercury concentrations in Asiatic clams (Corbicula fluminea) collected from the discharge plumes of the Savannah River creeks $(0.044 \mu \mathrm{g} / \mathrm{g}$ wet weight) were approximately 2.5 times higher than in clams collected from the Savannah River upstream from the creek mouths $(0.017 \mu \mathrm{g} / \mathrm{g}$ wet weight). This pattern was observed for both SRS and off-site creeks. High mercury concentrations in the clams were apparently the result of elevated methylmercury levels in the creek water $(0.170 \mathrm{ng} / \mathrm{l})$, which were nearly twice as high as in the Savannah River water $(0.085 \mathrm{ng} / \mathrm{l})$. All of the tributaries drained extensive wetlands that would be expected to support comparatively high rates of methylation. 
The findings of the Asiatic clam study together with the finding of strongly elevated mercury levels in Fourmile Branch swamp water in the first study suggest that the floodplain swamps along the Savannah River may be important sources of methylmercury. Apart from this study, little research has been conducted on the production of methylmercury in southeastern floodplain swamps and its transport to river ecosystems. Mercury dynamics in southeastern floodplain swamps may have a significant influence on mercury levels in river fishes and should be considered when developing TMDL recommendations.

The fourth study determined the influence of atmospheric deposition on the SRS. From January 2001 through January 2003, the Environmental Sciences \& Biotechnology Department of the Savannah River National Laboratory operated and maintained Station SC03 as part of the Mercury Deposition Network. During this period weekly measurements of concentration and deposition of total mercury in precipitation were obtained. The average concentration of total mercury in precipitation was $12.56 \mathrm{ng} / \mathrm{l}$ and the weekly deposition rate was $238.05 \mathrm{ng} / \mathrm{m}^{2}$. These observations were consistent with observations at other observations in South Carolina and in Georgia and consistent with EPA's estimate of $235 \mathrm{ng} / \mathrm{m}^{2}$ per week. Speciation of samples from the Savannah River Station indicated that less than $1.0 \%(\mathrm{p}=0.99)$ of the total mercury deposited is of the methyl species. This suggested that methylation occurred after deposition and prior to accumulation within fish.

Data from three additional stations in Georgia and South Carolina revealed monthly variations in concentration and deposition. Analysis of the monthly variation indicated that concentration and deposition were below the annual median in the winter and increased through the spring, reaching a maximum in late summer, and then rapidly declined below the annual median in the early fall.

To determine the extent and significance of the site's contribution of mercury to the Savannah River, a preliminary, very simplified mass balance was performed for total mercury at SRS. A mass balance is based on the principle of conservation of mass: input must equal accumulation plus output. For the SRS mercury mass balance, inputs included mercury discharged from SRS facilities to the environment through the NPDES outfalls, mercury transported to the site in the Savannah River upstream of the site boundary, mercury entering the SRS via streams originating outside of the site boundary, and atmospheric deposition. Outputs included mercury transported down the Savannah River at the downstream site boundary and re-volatilization. Influent mercury totaled approximately $30 \mathrm{~kg} / \mathrm{yr}$. Effluent mercury included $16.4 \mathrm{mg} / \mathrm{yr}$ via the river and an undetermined quantity re-volatilizing to the atmosphere. Assuming a balance, the sum of the mercury storage and re-volatilization within the boundary drawn for this study was approximately $13 \mathrm{~kg} / \mathrm{yr}$. Atmospheric deposition alone (17 kg/yr) far exceeded mercury transported by the SRS streams to the river $(1.1 \mathrm{~kg} / \mathrm{yr})$, indicating that approximately $95 \%$ of the deposited mercury was being retained in the soil, sediments, water bodies or vegetation, or was being re-emitted to the atmosphere. In addition, mercury released through the SRS outfalls was equivalent to approximately $1 \%$ of the total atmospheric deposition on the SRS, which confirmed that atmospheric deposition is the major source of mercury to the SRS environment and supported EPA's determination that point source discharges contribute only $1 \%$ of the mercury loading to the watershed.

In June 2002, EPA withdrew the TMDL for the middle and lower Savannah River. EPA stated that the TMDL was being withdrawn because the Savannah River was not impaired by total mercury according to Georgia's applicable water quality standards and was not listed on Georgia's Clean Water Act Section 303(d) list for mercury.

This report documents the completion of the sampling and analysis performed under this study, but is not intended to further support compliance to any new TMDL requirements. 


\section{Background}

High concentrations of mercury in fish tissue forced the state of Georgia to limit the consumption of fish in the Savannah River beginning in the year 2000. In turn, this declaration required that a Total Maximum Daily Load (TMDL) be determined for mercury in seven reaches of the Savannah River, including that portion adjacent to the Savannah River Site (SRS), a U.S. Department of Energy facility formerly used for the production of nuclear materials, as mandated by the Clean Water Act (USEPA 2001b). A TMDL is defined as the total mass of a pollutant that can be received by the water body that will result in a specified maximum acceptable water concentration or fish tissue concentration. Under a mercury TMDL, the Environmental Protection Agency (EPA) would restrict the loading of mercury into the watershed in order to reduce mercury concentrations in the river such that fish tissue concentrations would be reduced to meet the target concentration. In February 2000, EPA Region 4 issued a proposed TMDL for total mercury in the middle and lower Savannah River (USEPA 2000b). This TMDL limited the cumulative discharge of mercury (the waste load allocation) from all National Pollutant Discharge Elimination System (NPDES) point sources to 0.3 kilograms per year. The initial TMDL, which would have imposed a $1 \mathrm{ng} / \mathrm{l}$ mercury limit for all NPDES discharges to the middle/lower Savannah River, was revised to $2.8 \mathrm{ng} / \mathrm{l}$ in the final TMDL released in February 2001 (USEPA 2001b). A methylmercury criterion for water was not established at that time, but the existing tissue residue criteria of $0.3 \mathrm{mg}$ methylmercury $/ \mathrm{kg}$ fish remained in effect.

The implication for the SRS was that the site had to begin to consider actions to reduce potential mercury loadings into the river. However, at about the time the TMDL was being developed (in 1999 and 2000), the current environmental datasets describing mercury concentrations at the SRS were obtained using older analytical methods that did not estimate aqueous mercury concentrations less than $200 \mathrm{ng} / \mathrm{l}$. The method then in use was EPA Method 245.1, which had the above detection limit. There was a paucity of information at concentrations near $1 \mathrm{ng} / \mathrm{l}$, which demanded use of the newer ultra-low level EPA Method 1630/31 (Bloom and Crecelius 1983; Bloom and Fitzgerald 1988; USEPA 2001a). Therefore, a reassessment of environmental mercury was required at the SRS to facilitate possible compliance to new federal and state mercury loadings into the Savannah River watershed. The Savannah River National Laboratory's (then the Savannah River Technology Center) Environmental Analysis Section was given the task by the Environmental Protection Department to develop and execute a study to support future compliance needs in the form of an aquatic mercury assessment program (Halverson et al. 2000a). The objectives of this study were to investigate: 1) mercury in SRS discharges, SRS streams and the Savannah River, 2) mercury bioaccumulation factors for Savannah River fish, 3) the use of clams to monitor the influence of mercury from tributary streams on biota in the Savannah River, and 4) mercury in rainwater falling on the SRS. The results of these studies are presented in detail in this report.

Note that in June 2002, EPA withdrew the TMDL for the middle and lower Savannah River (USEPA 2002). EPA stated that the TMDL was being withdrawn because the Savannah River was not impaired by total mercury according to Georgia's applicable water quality standards and was not listed on Georgia's Clean Water Act Section 303(d) list for mercury. 


\section{Mercury in Savannah River Site Outfalls, Streams and the Savannah River}

\section{Introduction}

The Savannah River is formed by the confluence of the Tugaloo and Seneca Rivers in northeast Georgia and flows southeast through the Piedmont and Coastal Plain to the Atlantic Ocean. The Savannah River forms the border between South Carolina and Georgia and a portion of it borders the SRS. The SRS is drained by several Savannah River tributaries including Upper Three Runs, Beaver Dam Creek, Fourmile Branch, Steel Creek, and Lower Three Runs. These tributaries join the Savannah River at approximately River Kilometers (RKs) 253, 245, 242, 228, and 208 (River Miles [RMs] 157, 152, 150, 142, and 129), respectively. An extensive swamp region, referred to as the Savannah River swamp, is located adjacent to the river within the Savannah River Site boundary from the furthest upstream border on the river around Upper Three Runs downstream to the site border at the mouth of Lower Three Runs Creek.

SRS has a number of outfalls used to discharge wastewater to site streams and eventually the Savannah River. Wastewater may include cooling water, steam condensate, groundwater treated by air strippers, stormwater runoff, steam and air-conditioning condensates, laboratory drain wastewater, cooling tower blowdown and overflow, well flushing water, and other industrial and sanitary wastewater. These discharges are controlled by SRS's NPDES permit, which establishes limits for discharging pollutants and requires routine monitoring of these pollutants.

The purpose of this portion of the Aquatic Mercury Assessment was to determine total and methylmercury concentrations in the Savannah River, upstream of, adjacent to, and just downstream of the SRS, as well as in the major SRS streams which drain to the Savannah River. Selected samples were filtered to estimate particulate-bound fractions of total and methylmercury. Sampling of these water bodies was conducted during a three-year interval to estimate seasonal and spatial variability. A limited investigation of mercury in the Fourmile Branch swamp was also performed. Additionally, this portion of the Aquatic Mercury Assessment looked at total mercury concentrations in the SRS NPDES outfalls to determine whether they were significant sources of mercury to the Savannah River.

\section{Materials and Methods}

\section{General Sampling Plan}

Halverson et al. (2000b) has described the original sampling and analysis plan for this study in significant detail. In summary, the sampling plan was broken down into four major environments, 1) the SRS-NPDES outfalls which comprise regulated potential sources, 2) the Savannah River at stations just downstream of SRS's five major streams and upstream of the SRS, 3) at the stream mouths of Upper Three Runs, Beaver Dam Creek, Fourmile Branch, Steel Creek and Lower Three Runs and 4) at several stations within each of the major streams. Appendices A and B, respectively, indicate the NPDES outfall sampling stations and the SRS stream and Savannah River sampling stations.

\section{Field Sampling Method for Mercury}

The field sampling method is a modification of the EPA Method 1669, 'clean hands ... dirty hands'. This technique is intended to ensure that any object or substance that contacts the sample is nonmetallic and free from any material that may contain mercury. The greatest risk from contamination in sampling and analysis for mercury occurs during sample collection because the sample container is opened and filled in an uncontrolled environment (Bloom 1995). The collection method for dissolved mercury requires that the sample water be filtered through a 0.45 micron glassfiber filter which is provided by the analytical contractor. Sampling must be limited to no later than early afternoon on any sampling day to ensure that the samples are shipped overnight to the contracted laboratory. When preserved in ice and kept in a cooler the samples can be held no longer than 48 hours before they must be preserved at the analytical laboratory.

Laboratory Analysis for Total and Methylmercury

Samples were received by Frontier Geosciences, Inc. within 24 hours of collection and were preserved with $5 \mathrm{ml} / \mathrm{l}$ pre-tested 12N HCl. Water samples were analyzed for total mercury, using EPA low-level detection method 1631 (Bloom and Crecelius 1983, Bloom 1993), and for methylmercury, using EPA low-level detection method 1630 (Horvat et al. 1993; Liang et al. 1994). 


\section{Results}

\section{NPDES Outfall Results}

Quantile statistics for total mercury concentrations in the SRS outfalls are shown in Table 1 . The complete individual results are listed in Appendix C. Total mercury ranged from a low of $0.31 \mathrm{ng} / \mathrm{l}$ to a maximum of 604.00 $\mathrm{ng} / \mathrm{l}$ with a median value at $8.71 \mathrm{ng} / \mathrm{l}$, well below the limit of $50 \mathrm{ng} / \mathrm{l}$. The KSL Test for Normality (SAS 1995) indicated that the distribution for total mercury was not normal $(\mathrm{D}=0.061$, Probability of $>\mathrm{D}=0.001)$. Distribution fits indicated the data to be lognormally distributed (Chi-Square Test Value $=24.89, \mathrm{P}$ Value $=0.015$, Evans et al. 1993; Palisade Corp. 2002).

The current South Carolina Department of Health and Environmental Control water quality standard for mercury is $50 \mathrm{ng} / \mathrm{l}$. Although the standard applies to NPDES discharges after they enter the receiving stream, the number is useful for comparison with actual outfall concentrations. A very large number of the NPDES outfalls had concentrations well below the water quality standard, but several outfalls routinely had concentrations greater than $50 \mathrm{ng} / \mathrm{l}$ (Table 2). Outfalls A-01 and A-01A historically greatly exceeded the water quality standard. Outfall A-01A, which drained into Outfall A-01, received only groundwater air stripper effluent. The exact source of this mercury was unknown. In addition to the groundwater from Outfall A-01A, Outfall A-01 received noncontact cooling water, steam condensate, laboratory waste, cooling-tower overflow, well flush water, steam-cleaning rack wastewater and storm water runoff. At the time of this study, Outfall A-01 was located upstream of its current location. Now the outfall is located at the end of the A-01 Constructed Wetland treatment system, which mitigates the mercury levels to less than or equal to about $9 \mathrm{ng} / \mathrm{l}$. Outfall D-1A, a sanitary wastewater outfall, had sporadic concentrations exceeding $50 \mathrm{ng} / \mathrm{l}$. Outfall F-05, which received nonprocess cooling water and steam condensate from the Plutonium Fabrication Facility, well flush water and storm water, exceeded the waste quality standard only once. Outfall G-10 effluent from the Centralized Sanitary Wastewater Treatment Facility exceeded 50 ng/l once in May 2002. Sanitary wastewater from Outfall L-07A exceeded 50 ng/l twice, once in 2000 and once in 1999. Groundwater contaminated with mercury enters Outfall M-05 through its air stripper remediation system. Total mercury concentrations at Outfall M-05, without exception, exceeded $50 \mathrm{ng} / \mathrm{l}$. Since this study was completed, remediation measures have been implemented for Outfall M-05, as discussed in the "Discussion" section, below. All of the X-designated outfalls routinely exceeded $50 \mathrm{ng} / \mathrm{l}$. Outfall X-08 received water from Outfalls X-08A, B and C. This water was a combination of sanitary wastewater (Outfall X-08A), treated process water from the TNX Effluent Treatment Plant (Outfall X-08B), and treated groundwater air stripper effluent (Outfall X-08C). Outfall X-08C consistently reported the highest total mercury concentrations for all of the outfalls. Since the time of this study, however, most of the facilities discharging to the X-08 complex of outfalls have been dismantled and Outfall X-08C is the only X-designated outfall still active, as discussed in the "Discussion" section, below.

Although mercury previously had been detected in groundwater at the SRS (Price and Cook 1988; Oblath 1985), the source for the groundwater mercury in the TNX area is unknown. Looney et al. (1998) offers an excellent review of mercury occurrences in the groundwater of the SRS.

Table 1. Quantile statistics for total mercury (ng/l) at the SRS-NPDES outfalls for data collected from January 1999 to September 2002.

\begin{tabular}{lcc}
\hline Quantile & Percent & Value \\
\hline Maximum & $100.0 \%$ & 604.00 \\
& $99.5 \%$ & 604.00 \\
& $97.5 \%$ & 348.81 \\
& $90.0 \%$ & 138.00 \\
$3^{\text {rd }}$ Quartile & $75.0 \%$ & 51.50 \\
Median & $50.0 \%$ & 8.71 \\
$1^{\text {st }}$ Quartile & $25.0 \%$ & 3.34 \\
& $10.0 \%$ & 1.47 \\
& $2.5 \%$ & 0.74 \\
Minimum & $0.5 \%$ & 0.31 \\
\hline
\end{tabular}


Table 2. Total mercury concentrations (ng/l) at SRS NPDES outfalls from samples collected from August 1999 through September 2002.

\begin{tabular}{|c|c|c|c|c|}
\hline Outfall & No. of Samples & Minimum & Maximum & Mean \\
\hline$A-01^{a}$ & 6 & 7.2 & 96.9 & 46.6 \\
\hline$A-1 A^{b}$ & 7 & 103.0 & 186.0 & 139.4 \\
\hline A-11 & 8 & 16.8 & 37.6 & 27.4 \\
\hline D-1A & 5 & 9.9 & 107.0 & 54.1 \\
\hline F-01 & 5 & 0.6 & 2.6 & 1.3 \\
\hline F-02 & 5 & 3.6 & 7.4 & 4.7 \\
\hline F-05 & 5 & 26.5 & 51.3 & 36.3 \\
\hline F-08 & 9 & 1.2 & 10.4 & 3.2 \\
\hline G-10 & 7 & 6.4 & 73.7 & 21.7 \\
\hline H-02 & 6 & 6.4 & 8.5 & 7.1 \\
\hline $\mathrm{H}-04$ & 3 & 1.1 & 8.0 & 4.1 \\
\hline H-07 & 1 & 7.4 & 7.4 & 7.4 \\
\hline H-08 & 6 & 1.1 & 6.6 & 3.5 \\
\hline $\mathrm{H}-12$ & 6 & 2.6 & 6.4 & 4.4 \\
\hline H-16 & 2 & 5.7 & 6.6 & 6.2 \\
\hline K-04 & 3 & 8.0 & 24.4 & 16.7 \\
\hline K-06 & 3 & 2.3 & 9.8 & 6.0 \\
\hline $\mathrm{K}-12$ & 5 & 3.7 & 16.6 & 7.5 \\
\hline K-18 & 6 & 0.9 & 1.7 & 1.3 \\
\hline L-07 & 8 & 1.5 & 6.0 & 2.7 \\
\hline L-07A & 5 & 21.7 & 77.8 & 42.8 \\
\hline L-08 & 3 & 0.6 & 3.3 & 1.8 \\
\hline $\mathrm{M}-05^{\mathrm{c}}$ & 6 & 54.1 & 169.0 & 105.1 \\
\hline PP-1 & 2 & 0.3 & 28.5 & 14.4 \\
\hline S-04 & 5 & 1.2 & 8.9 & 4.6 \\
\hline $\mathrm{X}-04$ & 4 & 15.3 & 190.9 & 101.5 \\
\hline X-08 & 7 & 101.1 & 436.0 & 194.5 \\
\hline$X-08 A^{d}$ & 5 & 18.8 & 52.1 & 33.7 \\
\hline$X-08 B^{d}$ & 3 & 36.8 & 121.0 & 84.0 \\
\hline$X-08 C^{d}$ & 4 & 319.0 & 604.0 & 443.2 \\
\hline
\end{tabular}

Mercury in the Savannah River Site Streams

Sampling in the SRS streams at 17 locations began in June 1999 and ended in September 2002 with a majority of the sampling occurring on a quarterly frequency. All of the results are detailed in Appendices D and E. Using a competitive distribution fitting technique (Palisade 2002) a lognormal distribution best fit the results for both total and methylmercury (Chi-Square $=33.00, \mathrm{P}=0.017)$.

Total mercury ranged from a maximum of $15.71 \mathrm{ng} / \mathrm{l}$ in Upper Three Runs at Rt. 125 to a minimum of $0.95 \mathrm{ng} / \mathrm{l}$ in Fourmile Branch at Rt. 125 (Table 3). Other relatively high values included $13.30 \mathrm{ng} / \mathrm{l}$ in Lower Three Runs at 
Patterson Mill Rd. and 10.10 ng/l in Pen Branch at Rd. 13.2. Mean concentrations ranged from 5.26 ng/l in Tims Branch at the swamp to a low mean of $2.39 \mathrm{ng} / \mathrm{l}$ in Pen Branch at Rt. 125. The next highest mean value was in Tims Branch at Steeds Pond, based on 9 samples collected. The overall mean concentration for total mercury in the SRS streams was $3.67 \mathrm{ng} / \mathrm{l}$. Most importantly none of the stream sampling stations had total mercury concentrations near the $50 \mathrm{ng} / \mathrm{l}$ water quality standard.

Methylmercury concentrations ranged from a very low 0.002 ng/l in Upper Three Runs at Tyler Creek Bridge to a maximum of $2.601 \mathrm{ng} / \mathrm{l}$ in Tims Branch at the swamp (Table 4), with an average of $0.294 \mathrm{ng} / \mathrm{l}$. Tims Branch at the swamp had the most consistently high methylmercury concentrations, with a mean concentration of $1.048 \mathrm{ng} / \mathrm{l}$ based on 9 sampling events. The next closest mean concentration occurred in Meyers Branch at Rd. 9. Concentrations near and above $1.0 \mathrm{ng} / \mathrm{l}$ indicate significant rates of methylation of inorganic mercury (Macalady et al. 2000).

Table 3. Total mercury (ng/l) in SRS streams from samples collected from June 1999 through September 2002.

\begin{tabular}{lcccc}
\hline Location & Minimum & Maximum & Mean & Std. Dev. \\
\hline Tims Branch at Steeds Pond & 1.73 & 8.45 & 4.56 & 2.70 \\
Tims Branch at swamp & 3.41 & 9.54 & 5.26 & 2.19 \\
Beaver Dam Creek at 400D & 2.12 & 4.87 & 3.24 & 1.13 \\
Upper Three Runs at Tyler Creek Bridge & 1.37 & 9.40 & 3.50 & 2.34 \\
Upper Three Runs at Rd. C & 1.09 & 8.86 & 2.93 & 3.33 \\
Upper Three Runs at Rt. 125 & 1.35 & 15.71 & 3.65 & 4.24 \\
Fourmile Branch at swamp & 2.03 & 8.52 & 3.95 & 1.90 \\
Fourmile Branch at Rd. C & 1.68 & 7.80 & 3.87 & 1.97 \\
Fourmile Branch at Rt. 125 & 0.95 & 5.96 & 2.88 & 1.59 \\
Pen Branch at Rt. 125 & 1.65 & 4.48 & 2.39 & 1.18 \\
Pen Branch at Rd. 13.2 & 1.74 & 10.10 & 3.29 & 2.46 \\
Meyers Branch at Rd. 9 & 1.47 & 8.40 & 3.37 & 3.36 \\
Steel Creek at Rt. 125 & 1.93 & 4.27 & 2.88 & 0.82 \\
Lower Three Runs at Patterson Mill Rd. & 1.82 & 13.30 & 4.29 & 3.84 \\
\hline
\end{tabular}

Table 4. Methylmercury (ng/l) in SRS streams from samples collected from June 1999 through September 2002.

\begin{tabular}{lcccc}
\hline Location & Minimum & Maximum & Mean & Std. Dev. \\
\hline Tims Branch at Steeds Pond & 0.024 & 0.362 & 0.213 & 0.116 \\
Tims Branch at swamp & 0.159 & 2.601 & 1.048 & 0.731 \\
Beaver Dam Creek at 400D & 0.056 & 0.133 & 0.087 & 0.034 \\
Upper Three Runs at Tyler Creek Bridge & 0.002 & 0.255 & 0.123 & 0.078 \\
Upper Three Runs at Rd. C & 0.066 & 0.256 & 0.136 & 0.072 \\
Upper Three Runs at Rt. 125 & 0.077 & 0.233 & 0.130 & 0.043 \\
Fourmile Branch at swamp & 0.039 & 1.500 & 0.400 & 0.456 \\
Fourmile Branch at Rd. C & 0.010 & 0.726 & 0.357 & 0.257 \\
Fourmile Branch at Rt. 125 & 0.007 & 0.293 & 0.135 & 0.100 \\
Pen Branch at Rt. 125 & 0.114 & 0.438 & 0.242 & 0.120 \\
Pen Branch at Rd. 13.2 & 0.084 & 0.393 & 0.185 & 0.092 \\
Meyers Branch at Rd. 9 & 0.117 & 0.886 & 0.419 & 0.368 \\
Steel Creek at Rt. 125 & 0.116 & 0.700 & 0.289 & 0.200 \\
Lower Three Runs at Patterson Mill Rd. & 0.099 & 0.675 & 0.272 & 0.196 \\
\hline
\end{tabular}


Mercury in the Savannah River

River water was collected at a total of 15 sampling stations in the Savannah River. Major sampling stations were located at and just downstream of the major site streams where they entered the river, as well as above Upper Three Runs, to represent river water upstream of SRS. A small number of samples were collected at minor sampling stations located approximately 100 meters above the other stream mouths in the river. Again, both total and methylmercury were sampled on an approximately quarterly frequency. All of the individual results for total and methylmercury, respectively, are listed in Appendices F and G.

Results from the major sampling stations are shown in Table 5. Total mercury ranged from a minimum of $0.62 \mathrm{ng} / \mathrm{l}$ at the Steel Creek station to a maximum of $43.94 \mathrm{ng} / \mathrm{l}$, also at the Steel Creek station (Table 5). The high mercury concentration measured at Steel Creek was from triplicate samples collected on April 17, 2001, in which all three samples showed elevated mercury levels. A review of operating data from the L Lake Dam indicated that water may have been released from the bottom of L Lake during that time rather from the upper elevations, which could affect mercury levels at the mouth of Steel Creek. Therefore, the data were not representative of normal conditions. The sampling site with the lowest mean concentration for total mercury was the Below Beaver Dam Creek station (2.27 $\mathrm{ng} / \mathrm{l})$. The sampling site with the highest mean concentration was the Steel Creek river station $(6.58 \mathrm{ng} / \mathrm{l})$. If the high data measured during the release from the bottom of L Lake are disregarded, the mean concentration for the Steel Creek river station was $2.91 \mathrm{ng} / \mathrm{l}$. Mean concentrations for most of the river stations were remarkably uniform at approximately $3 \mathrm{ng} / \mathrm{l}$. Overall means for the stream mouth stations (e.g. "At Upper Three Runs," etc.) and the river stations (e.g. "Above Upper Three Runs” and "Below Upper Three Runs,” etc.) were 3.86 ng/l and 2.83 ng/l, respectively.

Table 5. Total mercury (ng/l) in the Savannah River near SRS stream mouths from samples collected from June 1999 through September 2002.

\begin{tabular}{lcccc}
\hline Location & Minimum & Maximum & Mean $^{\mathbf{a}}$ & Std. Dev. $^{\mathbf{a}}$ \\
\hline Above Upper Three Runs & 1.91 & 3.26 & 2.51 & 0.42 \\
At Upper Three Runs & 1.04 & 7.36 & 2.76 & 1.87 \\
Below Upper Three Runs & 1.41 & 9.62 & 3.14 & 1.90 \\
At Beaver Dam Creek & 2.86 & 5.90 & 4.33 & 0.86 \\
Below Beaver Dam Creek & 1.38 & 3.67 & 2.27 & 0.45 \\
At Fourmile Branch & 1.78 & 10.16 & 3.74 & 2.03 \\
Below Fourmile Branch & 1.93 & 3.70 & 2.55 & 0.47 \\
At Steel Creek & 0.62 & $43.9^{\mathrm{b}}$ & $6.58^{\mathrm{b}}$ & $12.45^{\mathrm{b}}$ \\
Below Steel Creek & 1.79 & 5.85 & 2.87 & 1.15 \\
At Lower Three Runs & 0.96 & 3.74 & 2.30 & 0.88 \\
Below Lower Three Runs & 1.94 & 9.65 & 3.29 & 2.04 \\
\hline a & & &
\end{tabular}

a For each date that replicate samples were collected, the results for the replicates were averaged before being used in the overall sample location average and standard deviation to avoid biasing the data toward the replicate samples.

b Results were affected by samples collected on April 17, 2001 exhibiting very high levels of mercury. A review of operating data from the L Lake Dam indicated that water may have been released from the bottom of L Lake during that time.

Methylmercury concentrations in the Savannah River samples from major sampling stations (Table 6) varied from a low of $0.036 \mathrm{ng} / \mathrm{l}$ at the station above Upper Three Runs to a high of $7.54 \mathrm{ng} / \mathrm{l}$ at the mouth of Steel Creek. Mean values for methylmercury ranged from $0.082 \mathrm{ng} / \mathrm{l}$ above Upper Three Runs to $0.882 \mathrm{ng} / \mathrm{l}$ at the mouth of Steel Creek. The high maximum and mean values at Steel Creek were due to high values measured in triplicate samples from April 17, 2001, when water may have been released from the bottom of L-Lake, as discussed previously. The maximum and mean methylmercury concentrations for Steel Creek without the high April 17, 2001 data were 0.934 $\mathrm{ng} / \mathrm{l}$ and $0.237 \mathrm{ng} / \mathrm{l}$, respectively. The two locations with the highest maximum and average methylmercury 
concentrations were the stations downstream from the site's two large cooling reservoirs, L Lake (Steel Creek station) and Par Pond (Lower Three Runs Station). Overall means for the stream mouth stations and the river stations were $0.288 \mathrm{ng} / \mathrm{l}$ and $0.087 \mathrm{ng} / \mathrm{l}$, respectively.

Table 6. Methylmercury (ng/l) in the Savannah River near SRS stream mouths from samples collected from June 1999 through September 2002.

\begin{tabular}{|c|c|c|c|c|}
\hline Location & Minimum & Maximum & Mean $^{a}$ & Std. Dev. ${ }^{\text {a }}$ \\
\hline Above Upper Three Runs & 0.036 & 0.141 & 0.082 & 0.035 \\
\hline At Upper Three Runs & 0.063 & 0.357 & 0.158 & 0.089 \\
\hline Below Upper Three Runs & 0.042 & 0.154 & 0.089 & 0.033 \\
\hline At Beaver Dam Creek & 0.074 & 0.160 & 0.110 & 0.029 \\
\hline Below Beaver Dam Creek & 0.041 & 0.119 & 0.079 & 0.029 \\
\hline At Fourmile Branch & 0.055 & 0.599 & 0.147 & 0.117 \\
\hline Below Fourmile Branch & 0.043 & 0.415 & 0.088 & 0.047 \\
\hline At Steel Creek & 0.072 & $7.54^{b}$ & $0.882^{b}$ & $2.15^{b}$ \\
\hline Below Steel Creek & 0.040 & 0.246 & 0.094 & 0.058 \\
\hline At Lower Three Runs & 0.092 & 0.735 & 0.215 & 0.147 \\
\hline Below Lower Three Runs & 0.037 & 0.191 & 0.083 & 0.042 \\
\hline
\end{tabular}

a For each date replicate samples were collected, the results for the replicates were averaged before being used in the overall sample location average and standard deviation to avoid biasing the data toward the replicate samples.

b Results were affected by samples collected on April 17, 2001 exhibiting very high levels of mercury. A review of operating data from the L Lake Dam indicates that water may have been released from the bottom of L Lake during that time.

Replication Study in the Savannah River

In order to determine the variability of results in the field, a replication study was performed in April 2001 by collecting triplicate samples at each river station for both total and methylmercury. Based on three rapidly consecutive field samples, this variation represents variation from one water sample to the next and variation due to analytical differences in the laboratory. The individual results, shown in Tables 7 and 8, indicate good agreement among each of the triplicate sets. Variability between replicate samples was small enough to indicate that a single sample collected from each station during each sampling event would be sufficient to detect significant changes between sampling stations or temporal variations at a particular station.

Table 7. Triplicate total mercury (ng/l) concentrations in the Savannah River during April 2001.

\begin{tabular}{lccccc}
\hline Location & Replicate 1 & Replicate 2 & Replicate 3 & Mean & Std. Dev. \\
\hline Above Upper Three Runs & 2.61 & 3.04 & 2.44 & 2.700 & 0.310 \\
At Upper Three Runs & 3.09 & 3.01 & 3.04 & 3.045 & 0.043 \\
Below Upper Three Runs & 2.91 & 2.59 & 2.52 & 2.674 & 0.208 \\
At Beaver Dam Creek & 3.94 & 4.01 & 4.37 & 4.107 & 0.226 \\
Below Beaver Dam Creek & 2.56 & 2.03 & 2.29 & 2.293 & 0.264 \\
At Fourmile Branch & 5.84 & 5.71 & 7.19 & 6.247 & 0.820 \\
Below Fourmile Branch & 2.37 & 1.93 & 2.17 & 2.157 & 0.223 \\
At Steel Creek & $42.8^{\text {a }}$ & $43.9^{\mathrm{a}}$ & $43.3^{\mathrm{a}}$ & $43.4^{\mathrm{a}}$ & 0.571 \\
Below Steel Creek & 2.76 & 2.22 & 2.96 & 2.647 & 0.381 \\
At Lower Three Runs & 3.41 & 3.72 & 3.61 & 3.581 & 0.159 \\
Below Lower Three Runs & 3.01 & 3.78 & 2.91 & 3.232 & 0.477 \\
\hline
\end{tabular}

a Operating data indicates that water may have been released from the bottom of L Lake during this time. 
Table 8. Triplicate methylmercury (ng/l) concentrations in the Savannah River during April 2001.

\begin{tabular}{lccccc}
\hline Location & Replicate 1 & Replicate 2 & Replicate 3 & Mean & Std. Dev. \\
\hline Above Upper Three Runs & 0.124 & 0.121 & 0.115 & 0.120 & 0.005 \\
At Upper Three Runs & 0.357 & 0.331 & 0.309 & 0.332 & 0.024 \\
Below Upper Three Runs & 0.123 & 0.123 & 0.107 & 0.118 & 0.009 \\
At Beaver Dam Creek & 0.154 & 0.160 & 0.158 & 0.157 & 0.003 \\
Below Beaver Dam Creek & 0.119 & 0.095 & 0.097 & 0.104 & 0.013 \\
At Fourmile Branch & 0.599 & 0.497 & 0.471 & 0.522 & 0.068 \\
Below Fourmile Branch & 0.415 & 0.106 & 0.092 & 0.204 & 0.183 \\
At Steel Creek & $7.27^{\mathrm{a}}$ & $7.19^{\mathrm{a}}$ & $7.54^{\mathrm{a}}$ & $7.33^{\mathrm{a}}$ & 0.186 \\
Below Steel Creek & 0.106 & 0.115 & 0.117 & 0.113 & 0.006 \\
At Lower Three Runs & 0.620 & 0.735 & 0.583 & 0.646 & 0.079 \\
Below Lower Three Runs & 0.181 & 0.191 & 0.164 & 0.179 & 0.014 \\
\hline
\end{tabular}

a Operating data indicates that water may have been released from the bottom of L Lake during this time.

Relationship between Total and Methylmercury

Watras et al. (1995a, 1995b, 1995c) in several synoptic surveys in lakes of North America have documented a strong positive correlation between total and methylmercury. In this study all of the SRS stream and Savannah River station results were pooled together to examine this relationship. Here a Pearson product-moment correlation coefficient $=0.88$ (see Figure 1, SAS 1995) indicated a positive degree of association. The percentage of methylmercury to total mercury ranged from 0.08 to $34.05 \%$ having a median percentage of $6.70 \%$.

Dissolved and Particulate Fractioning of Mercury

Two sets of trials were performed to assess the relative percentage of total and methylmercury that were bound to particulates in the stream and river samples. In each set from the river and streams duplicate samples were filtered on five to six sampling dates. In the Savannah River (Figure 2) the particulate fraction for total mercury was almost uniform ranging from a mean of $41 \%$ to $57 \%$, with an overall mean of $50 \%$. The particulate percentages for methylmercury at river stations indicated a greater variability with a median range from approximately $37 \%$ just below Fourmile Branch to a low of about 9\% just below Beaver Dam Creek, with an overall mean of 25\%. There were large variations between individual methylmercury measurements from one sampling event to another.

The percentage of particulate total mercury in the SRS streams had a greater range than in the river with high mean values of 90\% in Steel Creek and Lower Three Runs to a low mean value of $28 \%$ in Pen Branch (Table 9). The mean over all the stream and stream mouth sampling stations was 55\%, so about half of the total mercury in the streams was particulate bound. Methylmercury percentages ranged from a very low mean in Lower Three Runs at the Savannah River, $6.4 \%$, to a maximum mean of $79 \%$ for Lower Three Runs at Patterson Mill, immediately upstream, with an overall mean of $39 \%$. Similar to the river stations, there were large variations in the particulate fractions for methylmercury in the stream samples.

Mercury in the Fourmile Branch Swamp

Although sampling in the SRS streams and Savannah River would offer an excellent first-order picture of surface water mercury movement from the SRS, another important feature of the Savannah River needed to be sampled to further characterize mercury transport offsite and into the river: the Savannah River swamp. This is the extensive swamp region which extends from the furthest upstream border on the river around Upper Three Runs downstream to the site border at the mouth of Lower Three Runs Creek. Three transects were sampled during July and August, 2002 in the swamp near the mouth of Fourmile Branch at about RK 241 (RM 150) on the Savannah River. While walking along each transect, surface water grab samples were collected from small shallow pools varying in size from a few feet in diameter and inches deep to fifteen feet in diameter and a foot deep. 


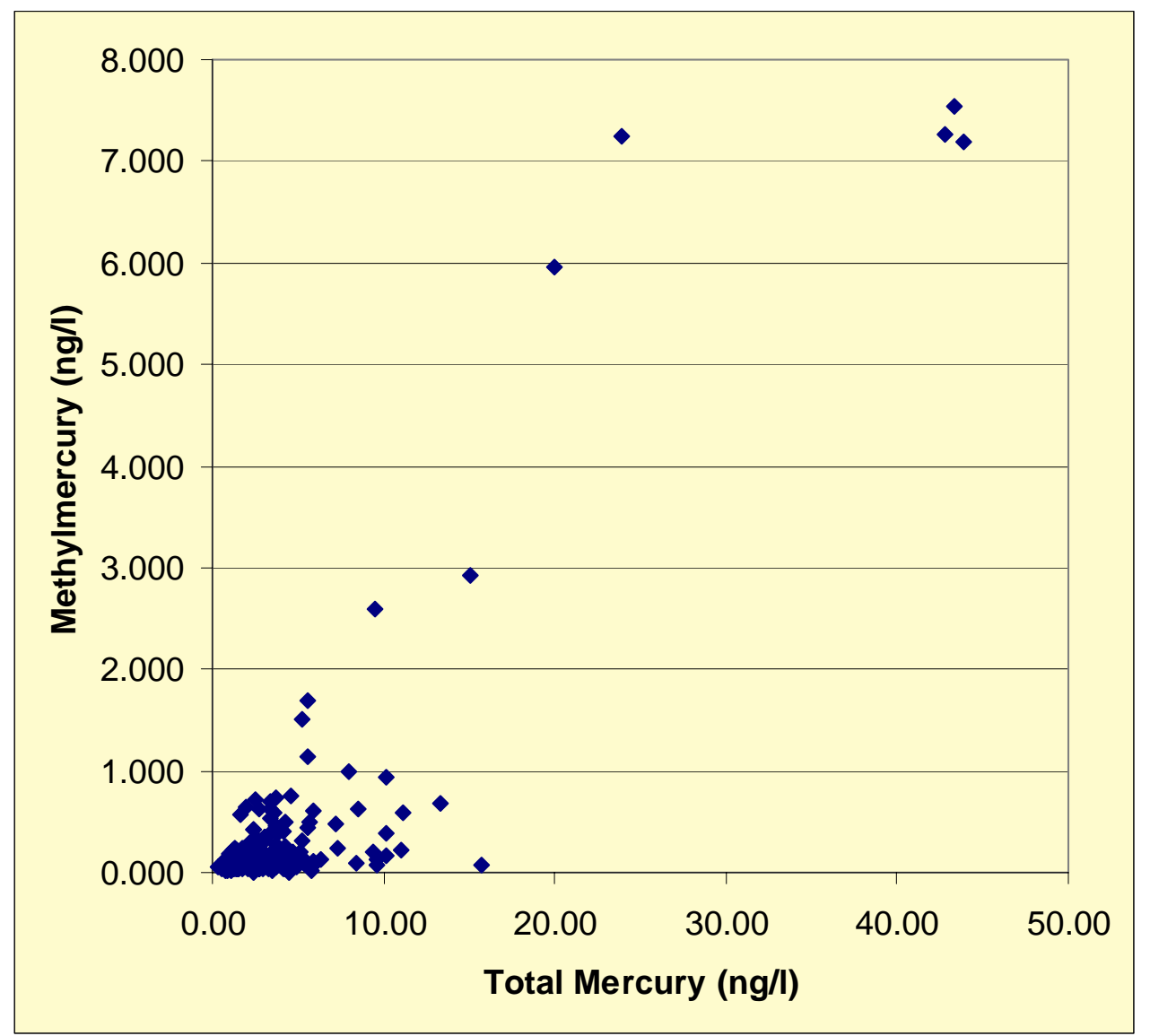

Figure 1. Relationship between total mercury and methylmercury based on SRS stream and Savannah River surface water samples. 


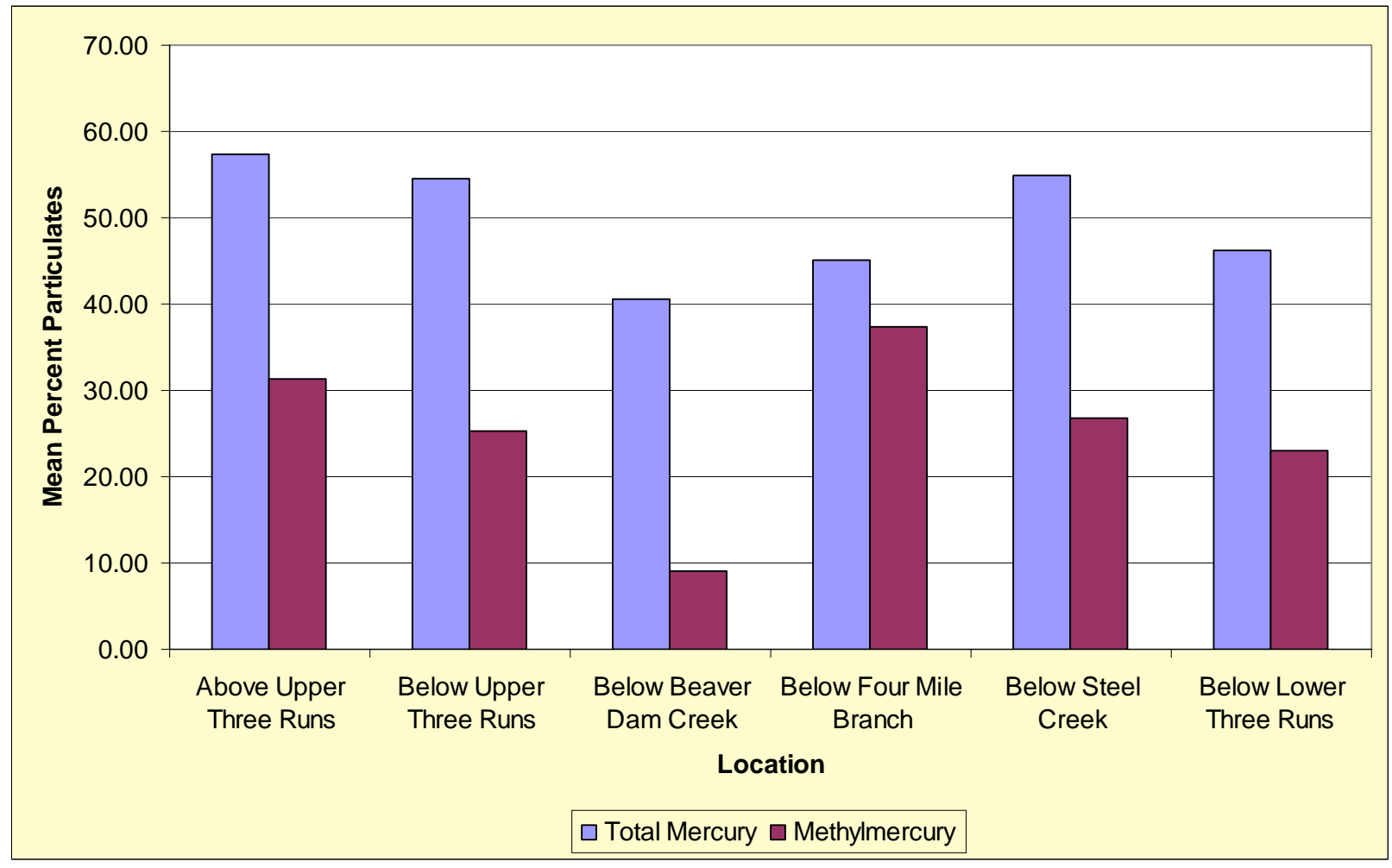

Figure 2. Mean of percent particulate fraction of total and methylmercury at Savannah River stations.

Table 9. Mean of percent particulate fraction of total and methylmercury at SRS stream and stream mouth stations.

\begin{tabular}{lcc}
\hline SRS Stream Location & $\begin{array}{c}\text { Mean of Percent Particulate, } \\
\text { Total Mercury }\end{array}$ & $\begin{array}{c}\text { Mean of Percent Particulate, } \\
\text { Methylmercury }\end{array}$ \\
\hline Upper Three Runs at Tyler Creek & 66.27 & 58.72 \\
Upper Three Runs at Rt. 125 & 41.22 & 21.60 \\
Upper Three Runs at Savannah River & 49.64 & 39.92 \\
Beaver Dam Creek at 400D & 47.36 & 60.33 \\
Beaver Dam Creek at Savannah River & 69.29 & 47.50 \\
Fourmile Branch at swamp & 37.55 & 27.10 \\
Fourmile Branch at Savannah River & 46.76 & 20.59 \\
Pen Branch at Rd. 13.2 & 27.90 & 33.89 \\
Steel Creek at Rt. 125 & 89.94 & 43.67 \\
Steel Creek at Savannah River & 55.65 & 28.06 \\
Lower Three Runs at Patterson Mill Rd. & 89.94 & 78.74 \\
Lower Three Runs at Savannah River & 35.13 & 6.43 \\
\hline
\end{tabular}

The results indicated that there were numerous localized areas that had extremely high concentrations of both total and methylmercury (Table 10). The range in total mercury concentrations was approximately a thousand-fold over the three transects. Methylmercury varied by a factor greater than 200. The extremely high concentrations reported here were comparable to other wetland habitats (Gilmour et al. 1998, Benoit et al. 1999). Ephemeral pools such as these could be significant sources of mercury release into the Savannah River if they are common throughout the 
swamp. At a minimum they are important points of exposure to wildlife. Deer and feral pig tracks were common in and around these pools and the swamp in general.

Table 10. Total and methylmercury concentrations from small shallow pools in the Fourmile Branch swamp, Savannah River Site, July 10, 11 and August 1, 2001.

\begin{tabular}{ccc}
\hline Transect Number & Total Mercury (ng/l) & Methylmercury (ng/l) \\
\hline 1 & 74.20 & 1.54 \\
1 & 118.00 & 1.95 \\
1 & 4.77 & 0.19 \\
1 & 1.93 & 0.17 \\
1 & 708.00 & 1.58 \\
1 & 402.00 & 1.54 \\
2 & 9.73 & 7.03 \\
2 & 13.20 & 8.15 \\
2 & 57.80 & 21.00 \\
2 & 55.20 & 21.60 \\
2 & 12.10 & 4.53 \\
2 & 15.90 & 4.29 \\
2 & 641.00 & 31.40 \\
2 & 440.00 & 34.70 \\
2 & 4.83 & 0.21 \\
2 & 1.98 & 0.17 \\
3 & 9.89 & 1.71 \\
3 & 1890.00 & 10.91 \\
3 & 96.40 & 2.15 \\
3 & 2.73 & 0.62 \\
\hline
\end{tabular}

\section{Discussion}

Groundwater contamination was the most important source for mercury in the SRS-NPDES outfalls. High concentrations were observed mainly at the old location of the Outfall A-01 complex, Outfall M-05 and the Outfall X-08 complex. All three outfalls received large contributions of treated groundwater from air strippers. The constructed wetland upstream of the new Outfall A-01 location has now reduced mercury concentrations to well below the water quality standard (Nelson et al. 2002). Outfall M-05 emptied into Outfall A-11 which diluted mercury concentrations to below the $50 \mathrm{ng} / \mathrm{l}$ water quality standard at the time of this study. Since that time, SRS began operating a stannous chloride injection system to chemically reduce and volatilize mercury at the air stripper groundwater treatment unit which discharges to Outfall M-05, reducing the concentration of mercury at the outfall to below the discharge limit. At the Outfall X-08 complex, mercury was also diluted by the receiving stream, the Savannah River itself, which kept concentrations below water quality standards. Since the time of this study, nearly all facilities discharging to the X-08 outfall complex have been shut down and dismantled. Outfalls X-08, X-08A, and X-08B ceased to be NPDES permitted outfalls in 2003. Only Outfall X-08C, which has a relatively low flow of $230 \mathrm{~m}^{3} / \mathrm{d}$ (0.06 million gallons per day), remains to receive effluent from the air stripper groundwater treatment unit.

Many of the total and methylmercury concentrations observed in SRS streams and the Savannah River were similar to other surveys in the southeastern United States. Below are listed some of the results in the EPA Region 4's own studies for the TMDL Program in Georgia compared with results from this study (Table 11). Most of the concentrations observed in the SRS streams and SRS reach of the Savannah River were near those reported by the EPA (see USEPA 1997b, 1997c). Certainly SRS streams are transporting meaningful amounts of mercury downstream into the swamp areas and into the river. Most consistent in these stream results were the relatively 
higher concentrations in Tims Branch at the 'swamp in' station. The most probable explanation for this 'hot spot' is that the conditions for significant rates of methylation of inorganic mercury are present in and around this sampling station, and that demethylation rates are much lower (USEPA 1997b). High rates of methylation require significant populations of sulfate-reducing bacteria, adequate amounts of sulfate and dissolved organic carbon and primarily anoxic conditions (USEPA 1997b).

Table 11. Total and methylmercury concentrations in this study compared with other surveys in the southeastern United States.

\begin{tabular}{llcc}
\hline Geographical region & Reference & $\begin{array}{c}\text { Range Total } \\
\text { Mercury (ng/l) }\end{array}$ & $\begin{array}{c}\text { Range Total } \\
\text { Methylmercury (ng/l) }\end{array}$ \\
\hline SRS streams & this study & $0.95-15.71$ & $0.002-2.601$ \\
Savannah River at SRS stations & this study & $0.62-43.94$ & $0.037-7.542$ \\
Savannah River Site Swamp & this study & $1.93-1890.00$ & $0.17-34.700$ \\
Savannah River outside of SRS & USEPA 2001b & $0.27-9.50$ & $0.021-0.390$ \\
$\quad$ Savannah River below Clark's Hill Dam & USEPA 2001b & 0.27 & 0.02 \\
Savannah River below Upper Three Runs & USEPA 2001b & 3.27 & 0.07 \\
Savannah River below Lower Three Runn & USEPA 2001b & 9.50 & 0.06 \\
Savannah River below Ebenezer Creek & USEPA 2001b & 3.44 & 0.08 \\
Savannah River - Tide Gate Freshwater & USEPA 2001b & 4.44 & 0.09 \\
Savannah River - Tide Gate Estuary & USEPA 2001b & 4.09 & 0.06 \\
Horse Creek & USEPA 2001b & 6.16 & 0.24 \\
Butler Creek & USEPA 2001b & 2.14 & 0.39 \\
Ebenezer Creek & USEPA 2001b & 3.34 & 0.65 \\
Alapaha River, Georgia & USEPA 2001c & $1.65-16.60$ & $0.465-2.630$ \\
Chattahoochee River, Georgia & USEPA 2001c & $0.30-1.50$ & $0.030-0.060$ \\
Kinchafoonee River, Georgia & USEPA 2001c & $1.60-3.20$ & $0.070-0.120$ \\
Everglades (water column) & USEPA 2001c & $0.89-3.90$ & $0.090-1.200$ \\
\hline
\end{tabular}

In the river samples total mercury concentrations were similar regardless of location. Variations were episodic in nature and did not follow any discernable patterns with regard to location or season. A possible source for these pulses was L Lake. Reservoirs are known to export significant amounts of mercury, especially when water is released from an anoxic hypolimnion (Schetagne et al. 2000; Canavan et al. 2000), as may have been occurring in April of 2001 when high levels of mercury were measured in Steel Creek.

The results here also indicated that, like other reported habitats, particulate mercury accounted for about half of the total mercury observed (Schetagne et al. 2000, Gray et al. 2000). In the SRS streams the average percentage for total mercury was $55 \%$ versus $50 \%$ in the Savannah River. The slightly higher percentage for the streams compared to the river is not surprising because particulate concentrations are generally greater in the streams where particulate runoff and sediment resuspension from stream flows occur. The overall mean concentrations for total mercury were $3.67 \mathrm{ng} / \mathrm{l}$ in the SRS streams, $3.86 \mathrm{ng} / \mathrm{l}$ in the SRS stream mouths, and $2.83 \mathrm{ng} / \mathrm{l}$ in the river. Therefore, SRS streams were contributing to the increasing of concentrations in the immediate reaches of the Savannah River.

The highest concentrations reported in this study and some of the highest concentrations reported for the southeastern United States were observed in the Fourmile Branch swamp transects. These concentrations, greater than $500 \mathrm{ng} / \mathrm{l}$, have been observed downstream from mercury mines in southwestern Alaska (Gray et al. 2000). These 'hot spots' in small pools raise questions as to their origins and to their effects as downstream sources to the river and exposure points for wildlife. There have been no industrial sources in this immediate area, because this swampland area has never been occupied or used for any industrial purpose. However, sediment transport through decades of movement could have created these areas. Elevated mercury levels have been found in Savannah River sediments and water upstream of the Savannah River Site due to discharges from a chlor-alkali facility near Augusta, Georgia, which manufactures chlorine using a mercury-cell technique. This facility discharged up to $5 \mathrm{~kg}$ 
of mercury daily into the Savannah River from August 1965 until August 1970, at which time discharges were reduced to less than $0.1 \mathrm{~kg} / \mathrm{d}$ (Kvartek et al. 1994, Paller and Littrell 2007, Smith et al. 2007, Tilly and Wilhite 1972). Water was pumped from the Savannah River for use as makeup water to maintain the water level in Par Pond and as cooling water for various Savannah River Site facilities, including the reactors, which were operating when the chlor-alkali plant discharges were high. This water was then discharged to site streams (including Fourmile Branch) or recirculated through Par Pond, eventually returning to the river. During the period August 1965 to August 1970, input of mercury from the river to Par Pond, alone, was calculated to be $9 \mathrm{~kg}$ (20 lbs) (Albenesius 1972). Sediment samples collected in 1972 found elevated levels of mercury in sediments in the Savannah River downstream of the chlor-alkali plant, at the inlet to the pump houses used to supply Savannah River water to SRS, in the settling basins used to store the river input water before use in the reactors, and in some of the onsite streams that received river water (Tilly and Wilhite 1972). In addition, a study of mercury bioaccumulation in mosquitofish found mercury levels to be significantly higher in fish from the river or streams that had received Savannah River water input than in fish from streams that had not received Savannah River water input (Newman and Messier 1994). The use of contaminated river water during this period is expected to be the source of some of the mercury contamination in sediments in the SRS streams and Par Pond.

The three Fourmile Branch swamp transects sampled in this study represented only a very small localized area in the Fourmile Branch watershed. Are the swamp areas in the other large streams also contaminated to the extent indicated here? Additional transect sampling along the whole of the swamp region is recommended. Because the methylmercury concentrations were so high at some of these pools, a potential risk exists for wildlife that drinks water from these pools. A future effort should estimate exposure, uptake and bioaccumulation by wildlife in these areas.

The results, seen in total, indicate noteworthy amounts of mercury reside in the stream and swamp sediments of the SRS. Some of this mercury, especially in the swamp, is methylated, resulting in surface water concentrations rarely observed in this part of the country. Eventually, some of this mercury will be transported, mainly as resuspended sediments, into the Savannah River. The degree of this downstream transport should be quantified. 


\section{Mercury Bioaccumulation Factors for Savannah River Fish}

\section{Introduction}

Mercury is a neurotoxic contaminant that is widespread in aquatic ecosystems. Mercury accumulates in fish primarily as methylmercury (Bloom 1992), which is produced in aquatic environments by the action of microorganisms on inorganic mercury (Gilmour et al. 1992). Mercury enters fish through their diet and concentrates in muscle tissues far in excess of ambient water levels (Clarkson 1990, Downs et al. 1998). Because of food chain bioaccumulation, concentrations in predatory fishes are usually higher than in fishes that feed at lower trophic levels (Cabana et al. 1994, USEPA 1997c). Consumption of contaminated fish (and other aquatic organisms) is the major route by which mercury enters human and wildlife food chains (Eisler 1987, Clarkson 1990).

The TMDL approach is being used to address aquatic contamination by mercury (USEPA 1994, USEPA 2001b). A mercury TMDL sets a target concentration for mercury in water, which is the maximum concentration of mercury that can be present without causing unacceptable bioaccumulation of mercury in fish (USEPA 2001b). Basic to TMDL accuracy is a realistic bioaccumulation factor (BAF), which is the ratio of the concentration of mercury in fish flesh to the concentration of mercury (usually dissolved methylmercury) in water (USEPA 1997c). Mercury BAFs are influenced by many factors including water chemistry, food chain lengths, temperature, and fish diet (Cope et al. 1990, Downs et al. 1998, Bowles et al. 2001). The EPA (1997c) has developed default BAFs for mercury that can be used when site specific data is lacking. These are based largely on fish and water chemistry data collected from northern lakes that may differ chemically and ecologically from running waters, particularly those in other geographic regions.

Collection of representative data for computation of site specific BAFs is complicated by temporal and spatial variations in aqueous and fish tissue mercury levels. Aqueous mercury levels are affected by many factors including oxygen concentration, precipitation, temperature, water level, and wetland runoff (Sellers et al. 2001, Hurley et al. 1998a, Regnell et al. 1997). Although less variation would be expected in fish muscle tissue (Downs et al. 1998, Foster et al. 2000), where the biological half life of mercury can be one to three years (McKim et al. 1976, Burrows and Krenkel 1973), at least one study suggests substantial seasonal variation in fish tissue mercury as a possible consequence of variations in mercury uptake (Park and Curtis 1997). Also, localized aggregations of fish from the same water body may exhibit significant spatial variations in mercury concentration as a likely result of differences in mercury bioavailability among foraging areas (Munn and Short 1997). The influence of these sources of variation on the representativeness and precision of site specific BAFs is poorly known.

In this study, aqueous and fish mercury samples were collected during several seasons and at several locations in the middle Savannah River. The objectives were 1) to determine mercury BAFs for the Savannah River, a habitat that differs substantially from the northern lakes that have been the subject of most BAF related studies, and 2) to assess the effects of seasonal and spatial variations in aqueous and fish tissue mercury concentrations on BAF variability.

\section{Materials and Methods}

\section{Study Area}

The approximately $110 \mathrm{~km}$ (68 mi) reach of the Savannah River under study extended from below the Augusta Lock and Dam (RK 302 or RM 188) to the Highway 301 bridge (RK 192 or RM 119). For part of its length it is adjacent to the SRS (Figure 3). Earlier studies showed that dissolved oxygen concentrations within the study area averaged seven to eight mg/l, pHs were slightly acidic (around 6.0), and conductivities averaged nearly $70 \mu \mathrm{S} / \mathrm{cm}$. (Paller et al. 1986). The study area included a number of "cut-off bends” or artificial oxbow lakes (hereafter referred to as "cuts") formed where loops of the river channel were by-passed by the Army Corps of Engineers during the 1960s to improve navigation efficiency. Although most cuts were still connected to the main river channel, the flow through them was reduced and dissolved oxygen concentrations were lower (nearing zero in a few backwater areas during warm weather, Paller et al. 1986). Cuts were heavily fished by anglers, suggesting the importance of including them in a BAF study ultimately concerned with human exposure to mercury. 


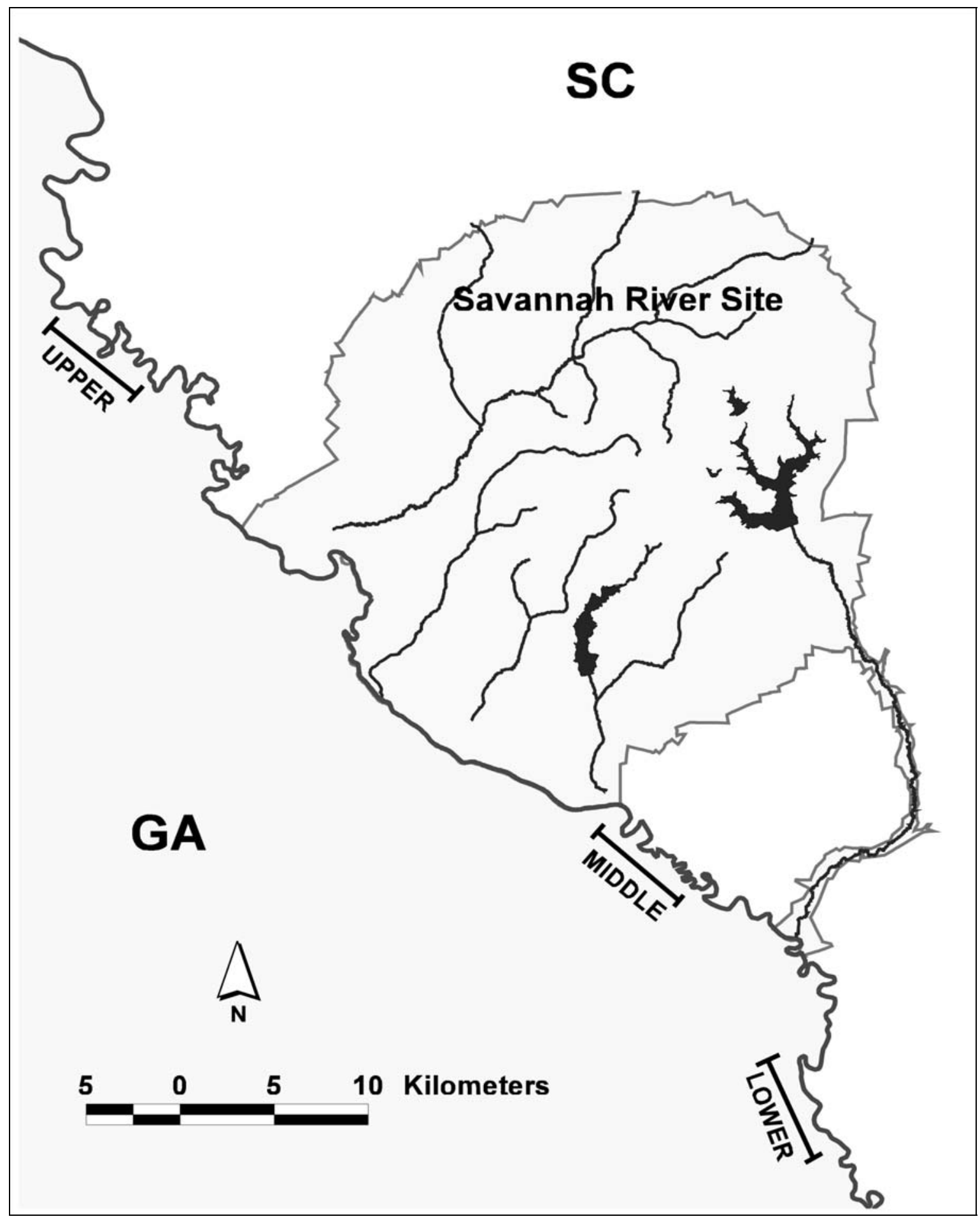

Figure 3. Map showing Savannah River sample areas from which fish and water were collected for mercury analysis. 
Field and Laboratory Methods

Fish and water samples were collected from three locations in the Savannah River: "upper river" (approximately RK 300 - RK 290 or RM 186 - RM 180), “middle river” (approximately RK 223 - RK 213 or RM 139 - RM 132), and "lower river" (approximately RK 190 - RK 182 or RM 118 - RM 113) (Figure 3). Each sampling location included two habitats, the main river channel and the backwaters found in cuts connected to the main channel. Two cuts were sampled in each location. Samples were collected during three time periods: fall 2000, spring 2001, and late summer 2001. Fall 2000 included fish samples collected from 9/19/00 through 11/15/00 and water samples collected on 11/6/00 and 11/7/00. Spring 2001 included fish samples collected from 2/27/01 through 5/15/01 and water samples collected on 4/26/01. Late summer 2001 included fish samples collected from 8/20/01 through 10/8/01 and water samples collected on 9/10/01 and 9/11/01.

Each habitat was electrofished to collect representatives from three taxonomic groups: largemouth bass Micropterus salmoides, white catfishes Ameiurus catus, and sunfishes (Lepomis spp). Sunfishes included redbreast sunfish Lepomis auritus, redear sunfish Lepomis microlophus, and bluegill Lepomis macrochirus. The pooling of sunfishes was necessary because of the limited availability of individual species. Extensive areas were sampled in an effort to collect at least five individuals from each taxonomic group in each habitat, location and sample period. However, this goal was not always met (sample sizes given in results).

Fish were transferred to polyethylene zip-lock bags immediately after collection, placed on ice and brought to a laboratory where they were individually measured (total length to nearest $\mathrm{mm}$ ) and weighed (nearest g). A muscle tissue sample weighing approximately $10 \mathrm{~g}$ was removed from the lateral posterior portion of each fish and frozen. In some cases, stomach contents were qualitatively evaluated to determine what the fish had been eating. Fish tissue samples were individually analyzed at the SRS Environmental Monitoring Laboratory for total mercury ( $\mu \mathrm{g} / \mathrm{kg}$ wet weight) using EPA method 245.6 (cold vapor atomic absorption spectrometry following tissue homogenization and digestion, USEPA 1991). Differences between replicate samples averaged $9 \%$ and all results were above the detection limit.

Two filtered water samples for dissolved methylmercury analysis were collected from each habitat (river and cut) in each location (upper, middle, and lower river) during each sample period. The two samples from the river were collected near the beginning and the end of each sampling location and the two samples from the cuts were collected from different cuts. Each sample was taken near the middle of the river or cut about $25 \mathrm{~cm}$ (10 in) beneath the surface. A peristaltic pump and clean plastic tubing conveyed water from the river through a 0.45 micron glassfiber filter into a pre-cleaned and marked Teflon bottle. New filters were used for each sample, and the collecting tube was thoroughly flushed with ambient water between samples. Sampling was performed with clean sample handling techniques to prevent contamination (Bloom 1995, USEPA 2001a). Samples were placed on ice and shipped the day of collection to a laboratory specializing in ultra-low level methylmercury analyses (Frontier Geosciences) using gas chromatography and cold vapor atomic fluorescence (Bloom 1989, USEPA 2001a).

Data Analysis

Analysis of covariance (ANCOVA) (Sokal and Rohlf 1981) was used to test differences in fish mercury levels among locations, habitats, and time periods while controlling for fish size (i.e., total length). Location, habitat, and time period means were compared with a least squares mean procedure that adjusted individual means to the average fish length (Searle et al. 1980). Failure to collect fish from some habitats during some sample periods made it impossible to test all main effects and interactions in a single model with all data. Instead, it was necessary to select portions of the data that permitted testing each hypothesis without incurring the problem of missing cells as discussed more fully later. Differences in aqueous mercury concentrations among locations, habitats, and time periods were tested with analysis of variance (ANOVA) (Sokal and Rohlf 1981). The two samples below detection limits were set equal to half the detection limit. Both fish tissue and aqueous mercury data were log transformed to meet statistical assumptions. Results were judged significant at $\mathrm{P}^{\leq} 0.05$.

Mercury BAFs are typically calculated by dividing the average mercury concentration in fish by the average dissolved methylmercury concentration (USEPA 1997b) to yield a single value without an estimate of variability. In this study, average BAFs plus 95\% confidence intervals (CIs) were calculated with a resampling procedure that involved randomly drawing (with replacement) a number of samples from the potential pools of aqueous and fish tissue mercury samples appropriate for each combination of habitat, location, and time period under examination. 
Averages were calculated for the randomly drawn aqueous samples and fish samples, and a BAF calculated by dividing the averages. This was repeated 20,000 times and the $2.5^{\text {th }}$ and $97.5^{\text {th }}$ percentile determined from the distribution of 20,000 BAFs. Coefficients of variation (CV) were computed by dividing the standard deviation of the BAF distribution by the average. Computations were performed with Resampling Stats (Simon 1999) and Resampling Stats in Excel (Blank et al.1999).

\section{Results}

Mercury in Fish Tissues

A total of 225 fish were collected: 60 during fall 2000 (24 largemouth bass, 28 sunfishes, and 8 white catfish), 71 during spring 2001 (26 largemouth bass, 30 sunfishes, and 15 white catfish), and 94 during late summer 2001 (32 largemouth bass, 40 sunfish, and 22 white catfish). Average total lengths (standard deviation, range) were $18.7 \mathrm{~cm}$ (3.4, 13-27) for sunfishes, $36 \mathrm{~cm} \mathrm{(5,} \mathrm{25-47)} \mathrm{for} \mathrm{white} \mathrm{catfish,} \mathrm{and} 31.2 \mathrm{~cm}(6.6,19-46)$ for largemouth bass. Fish tissue mercury concentrations (wet weight) ranged from 9 to $1200 \mu \mathrm{g} / \mathrm{kg}$, but over $80 \%$ were under $300 \mu \mathrm{g} / \mathrm{kg}$ (Figure 4). The arithmetic mean tissue mercury concentration for all species was $193 \mu \mathrm{g} / \mathrm{kg}$. However, the arithmetic mean was strongly influenced by a few extreme values. More representative measures of central tendency were the geometric mean and median: 130 and $128 \mu \mathrm{g} / \mathrm{kg}$, respectively. Geometric mean mercury concentrations for individual taxa were $209 \mu \mathrm{g} / \mathrm{kg}$ for largemouth bass, $147 \mu \mathrm{g} / \mathrm{kg}$ for white catfish, and $83 \mu \mathrm{g} / \mathrm{kg}$ for sunfishes. Examination of stomach contents indicated that largemouth bass ate mainly fish (Lepomis spp. and Dorosoma spp.), sunfishes ate aquatic insect larvae and other invertebrates, and white catfish ate aquatic insect larvae, molluscs (primarily Corbicula fluminea), other invertebrates, small numbers of fish, and detritus.

Because largemouth bass could not be collected consistently from the main channel, largemouth bass from main channel and cuts were pooled for the ANCOVA of location and sample period on tissue mercury levels ( $\mathrm{n}=81$ ). Largemouth bass total length was significantly related to tissue mercury concentrations $(\mathrm{P}<0.001)$, and the relationship between fish length and mercury concentration was consistent across categories (i.e., slopes were homogeneous). Largemouth bass tissue mercury levels differed significantly among locations $(\mathrm{P}<0.001)$ and among time periods $(\mathrm{P}=0.011)$, but there were no significant interactions. Size adjusted concentrations were highest in the lower river and lowest in the upper river and higher during spring 2001 than during the other sampling periods (Figure 5). An additional ANCOVA using only fall 2000 and late summer 2001 data, when bass were collected from both main channel and cut habitats at all locations $(n=32)$, indicated that habitat related differences in tissue mercury levels were not significant (size adjusted geometric mean tissue levels were $213 \mu \mathrm{g} / \mathrm{kg}$ for the main channel and $200 \mu \mathrm{g} / \mathrm{kg}$ for the cuts).

A preliminary ANCOVA with species as the categorical variable indicated a significant relationship between fish length and tissue mercury concentration but no significant differences among species for the three species pooled to produce the sunfish category, thus justifying pooling sunfishes for further testing. As with largemouth bass, inability to collect sufficient sunfishes from the main channel made it necessary to pool fish from both main channel and cuts $(\mathrm{n}=98)$ to test location and sample period. There was a significant relationship between total length and tissue mercury concentration $(\mathrm{P}<0.001)$ and a significant difference among locations $(\mathrm{P}<0.001)$ but not sample periods. As with largemouth bass, size adjusted sunfish tissue mercury levels were highest in the lower river and lowest in the upper river (Figure 5).

Data from the late summer 2001, when sunfish were collected in substantial numbers from the main channel and cuts at all sample locations, were used to test for differences in sunfish tissue mercury levels between habitats $(\mathrm{n}=40)$. This test indicated significant differences among both locations $(\mathrm{P}<0.001)$ and habitats $(\mathrm{P}=0.004)$ but no interaction. Size adjusted geometric mean sunfish tissue mercury levels were higher in the cuts $(117 \mu \mathrm{g} / \mathrm{kg})$ than in the river $(61 \mu \mathrm{g} / \mathrm{kg})$. Paralleling the previous tests, sunfish tissue mercury levels were highest in the lower river and lowest in the upper river.

Because a preliminary ANCOVA showed that tissue mercury levels in white catfish were not significantly related to fish length (possibly because the white catfish were comparatively uniform in size; i.e., total length $\mathrm{CV}=13.6 \%$ compared with $21.4 \%$ for largemouth bass and $18.4 \%$ for sunfishes), ANOVA rather than ANCOVA was used to test catfish for tissue mercury differences. The best test of sample period and habitat was with data collected from 


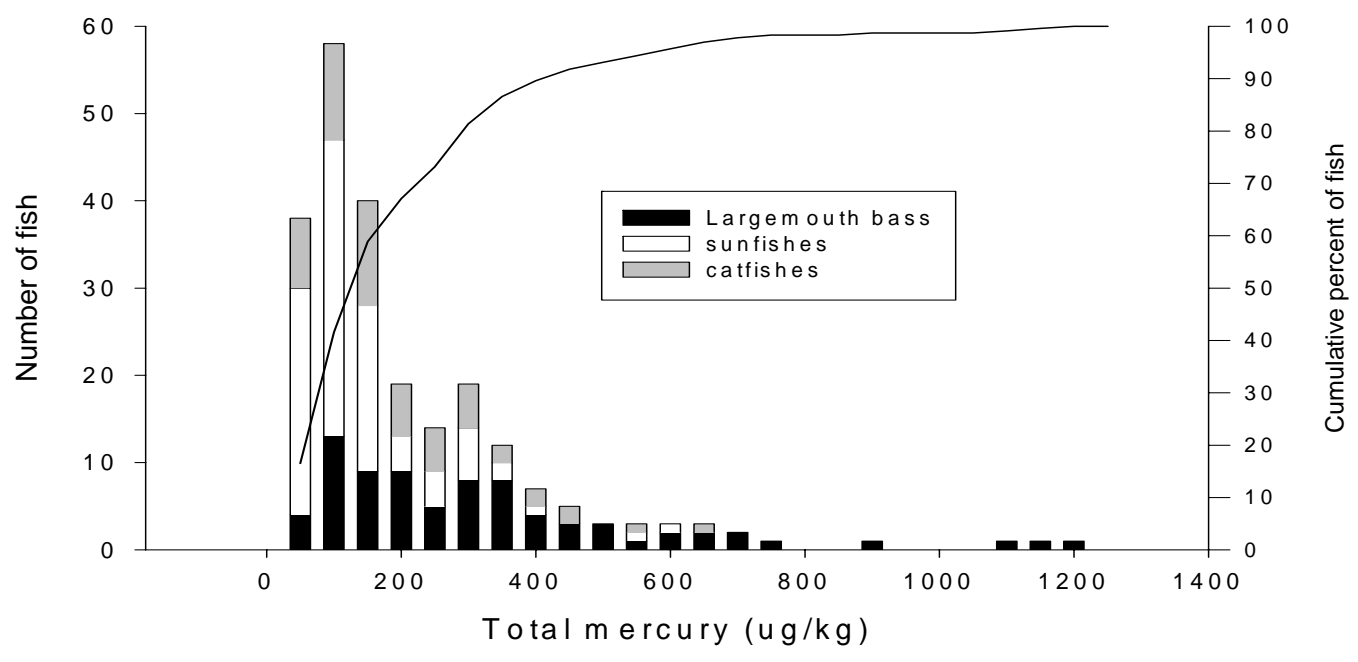

Figure 4. Total mercury concentrations in fishes collected from the Savannah River.
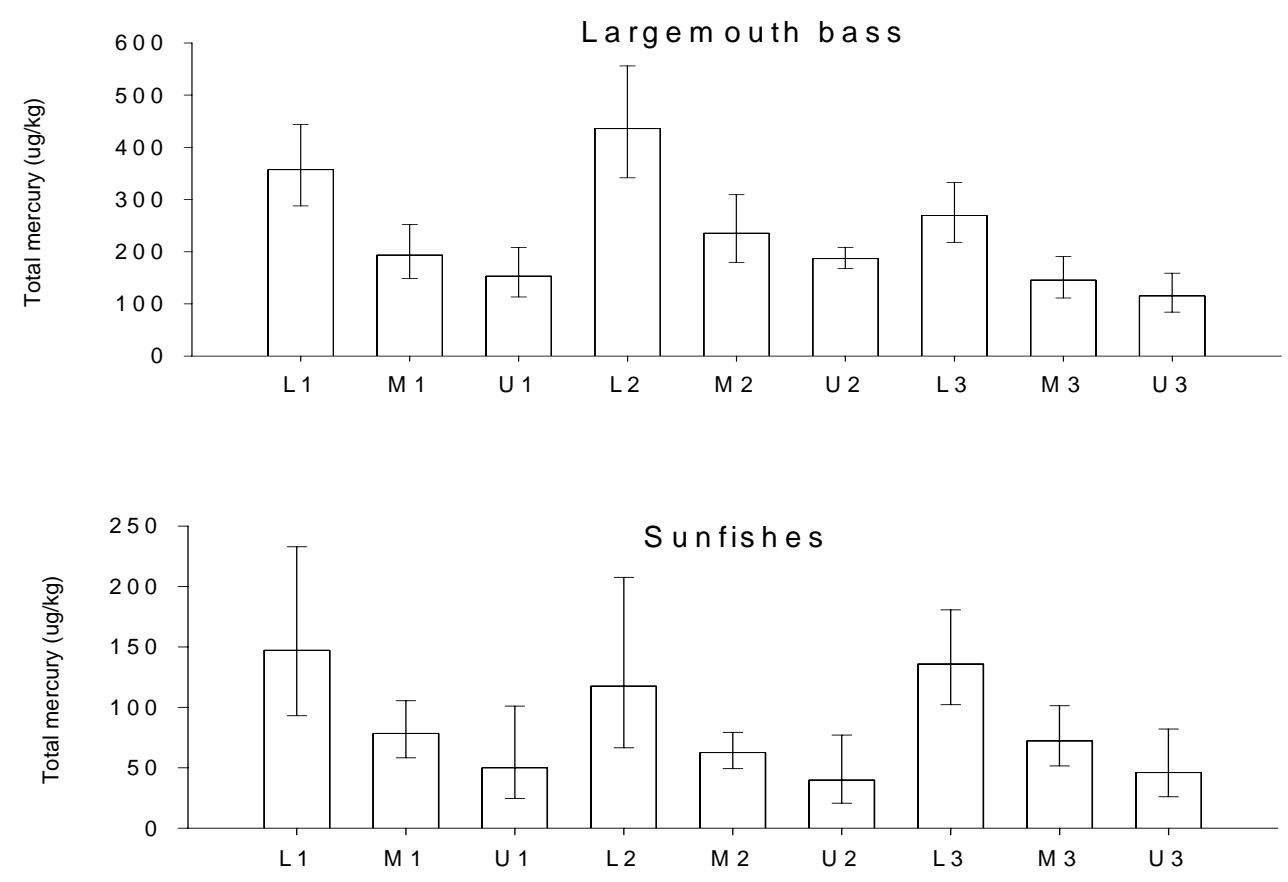

Figure 5. Size adjusted (least square) geometric mean total mercury concentrations (95\% confidence intervals) for largemouth bass and sunfishes collected from lower (L), middle (M) and upper (U) locations in the Savannah River during fall 2000 (1), spring 2001 (2), and late summer 2001 (3) 
the middle river, where white catfish were consistently collected from both river and cuts during all sample periods $(\mathrm{n}=28)$. There were significant differences among sample periods (0.012), but not habitats, nor were interactions significant. Geometric means were $281 \mu \mathrm{g} / \mathrm{kg}$ for fall 2000, $126 \mu \mathrm{g} / \mathrm{kg}$ for spring 2001 and $198 \mu \mathrm{g} / \mathrm{kg}$ for late summer 2001. Data from late summer 2001, when fish were collected from all locations, were used to test differences in catfish tissue mercury levels among locations $(\mathrm{n}=22)$. As with largemouth bass and sunfishes, location related differences were significant $(\mathrm{P}<0.001)$, with the highest levels in the lower river $(372 \mu \mathrm{g} / \mathrm{kg})$, intermediate levels in the middle river (198 $\mu \mathrm{g} / \mathrm{kg})$ and the lowest levels in the upper river (51 $\mu \mathrm{g} / \mathrm{kg})$.

\section{Methylmercury in Water}

Dissolved methylmercury concentrations in water ranged from $<0.014$ to $0.470 \mathrm{ng} / \mathrm{l}$ with most concentrations under $0.1 \mathrm{ng} / \mathrm{l}$. The arithmetic mean methylmercury concentration was $0.081 \mathrm{ng} / \mathrm{l}$ with a CV of $113 \%$. This average was strongly influenced by two high values $(0.38$ and $0.48 \mathrm{ng} / \mathrm{l})$ making the median $(0.054 \mathrm{ng} / \mathrm{l})$ and geometric mean $(0.057 \mathrm{ng} / \mathrm{l})$ more representative measures of central tendency. There were two aqueous methylmercury samples below the detection limit of $0.014 \mathrm{ng} / \mathrm{l}$

ANOVA of the log transformed methylmercury data indicated a significant difference among sample periods but no other significant main effects or interactions. Geometric mean mercury concentrations were 0.048 during fall 2000, 0.107 during spring 2001, and 0.036 during late summer 2001. Although dissolved aqueous methylmercury levels during spring 2001 were relatively high in both the river and cuts, the highest levels were in some of the cuts (Figure $6)$.

\section{Bioaccumulation factors (BAFs)}

Differences in fish tissue and aqueous mercury concentrations associated with season and location affected BAF estimates as illustrated by computing average BAFs for different river locations during different sample periods. Water samples were pooled over location because water concentrations did not differ significantly among locations. The average largemouth BAF varied three-fold from $2.4 \times 10^{6}$ to $6.8 \times 10^{6}$ depending upon location and time of collection (Figure 7). Sampling uncertainty was manifested in the 95\% CIs (confidence intervals) which reached as low as $1.1 \times 10^{6}$ and as high as $11.9 \times 10^{6}(\mathrm{n}=10$ each for fish and water). Time period alone caused largemouth bass BAFs (averaged over location) to vary by a factor of about $1.9\left(2.9 \times 10^{6}\right.$ to $\left.5.5 \times 10^{6}\right)$, and location alone caused largemouth bass BAFs (averaged over time period) to vary by a factor of about $1.7\left(2.7 \times 10^{6}\right.$ to $\left.4.6 \times 10^{6}\right)$. Average sunfish BAFs ranged from $0.6 \times 10^{6}$ to $3.4 \times 10^{6}$, a nearly six-fold difference. Time period alone caused sunfish BAFs to vary by about $3.0\left(0.8 \times 10^{6}\right.$ to $\left.2.3 \times 10^{6}\right)$, and location alone caused sunfish BAFs to vary by about $2.3\left(0.8 \times 10^{6}\right.$ to $\left.1.9 \times 10^{6}\right)$. Average white catfish BAFs ranged from $1.1 \times 10^{6}$ to $8.6 \times 10^{6}$, an approximately eightfold difference. Overall average BAFs (including fish and water data from all periods, locations, and habitats) for each taxonomic group were $3.7 \times 10^{6}\left(95 \% \mathrm{CI}=2.4 \times 10^{6}\right.$ to $\left.5.4 \times 10^{6}\right)$ for largemouth bass, $1.4 \times 10^{6}(95 \% \mathrm{CI}=0.9$ $\times 10^{6}$ to $\left.2.1 \times 10^{6}\right)$ for sunfishes, and $2.5 \times 10^{6}\left(95 \% \mathrm{CI}=1.6 \times 10^{6}\right.$ to $\left.3.7 \times 10^{6}\right)$ for white catfish.

BAFs were also calculated by using geometric mean fish tissue mercury and geometric mean aqueous methylmercury concentrations (since geometric means appeared to represent central tendency better than arithmetic means) and by using size adjusted geometric means (i.e., least squares geometric means) for fish tissue mercury in place of unadjusted geometric means (to control for differences in fish size among locations and time periods). Neither calculation substantially affected the differences among locations and time periods, although both reduced the confidence interval around individual means slightly. The lack of influence of the size adjusted geometric means indicated that BAF variability among locations and seasons was unrelated to fish size.

It was necessary to increase both fish and aqueous mercury sample sizes to reduce BAF uncertainty as shown by the overall average largemouth bass BAF. Changes in largemouth bass and water sample sizes had similar effects -very small sample sizes for either resulted in high BAF CVs (Figure 8). The effect of sample size on BAF uncertainty was further addressed by computing $95 \%$ confidence intervals for the overall average largemouth bass BAF. A sample size of five each for fish and water was associated with a confidence interval nearly $220 \%$ as large as the mean (Figure 9). As sample sizes for both increased, the confidence interval (expressed as a percentage of the mean) decreased asymptotically, reaching about $78 \%$ of the mean at a sample size of 50 each for fish and water. In addition to causing considerable uncertainty, small $(<10)$ fish and water sample sizes resulted in slightly elevated average BAFs and highly skewed BAF distributions because of the strong influence of atypical data points on fish 

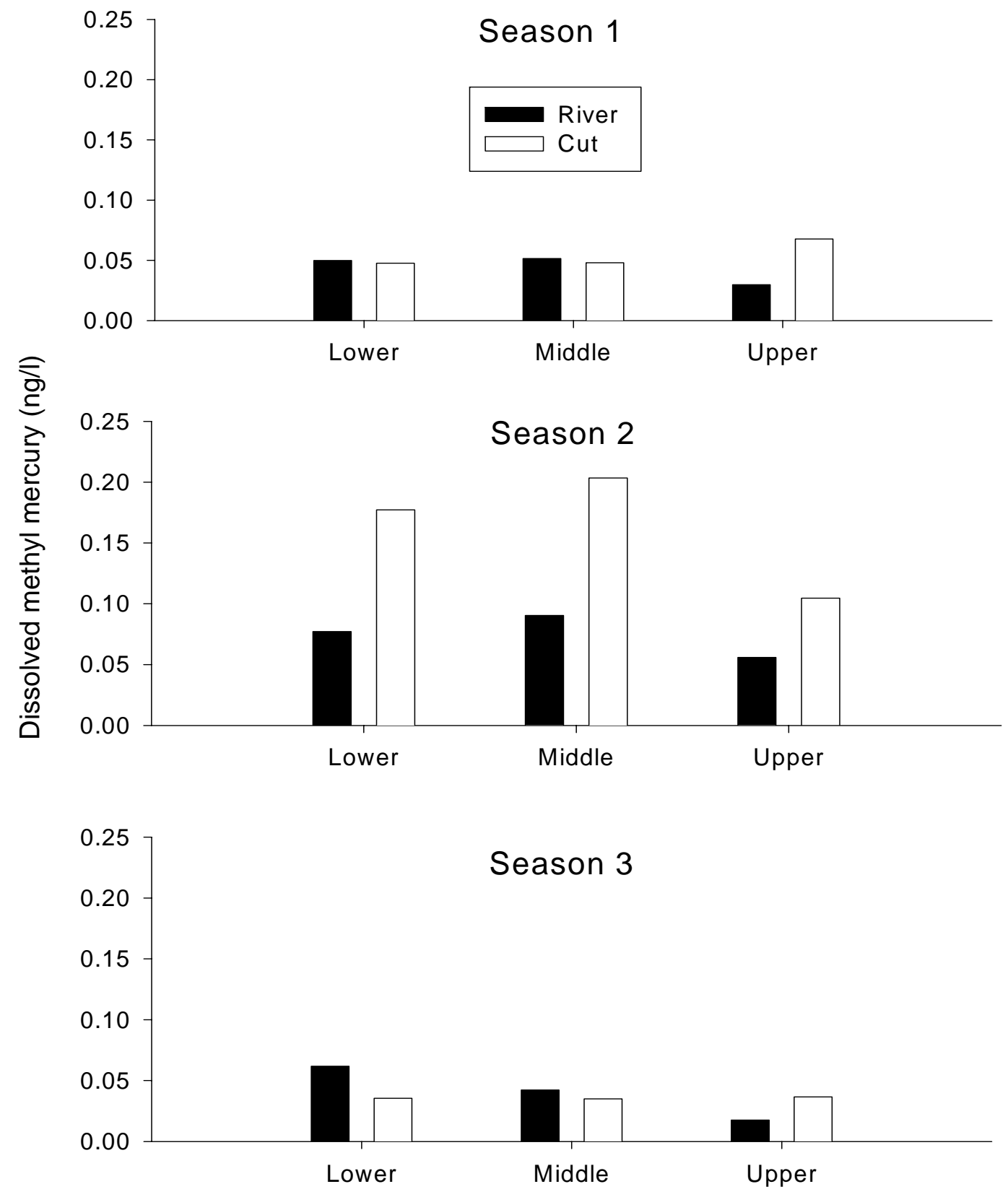

Figure 6. Geometric mean dissolved methylmercury concentrations at different locations and during different seasons in the Savannah River. 

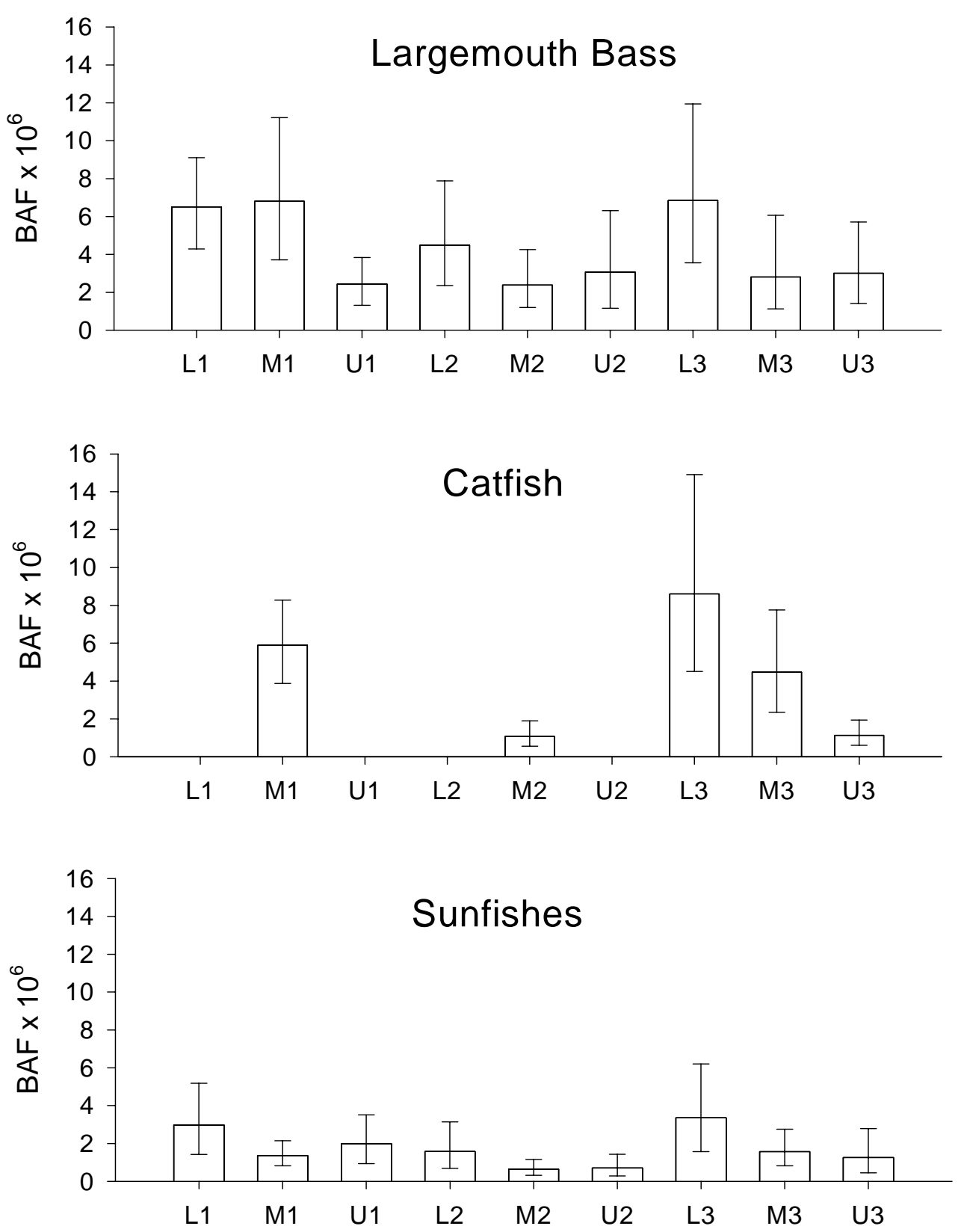

Figure 7. Average mercury bioaccumulation factors (95\% confidence intervals) for the lower (L), middle (M) and upper (U) locations in the Savannah River during fall 2000 (1), spring 2001 (2), and late summer 2001 (3). Confidence intervals were calculated by resampling. 


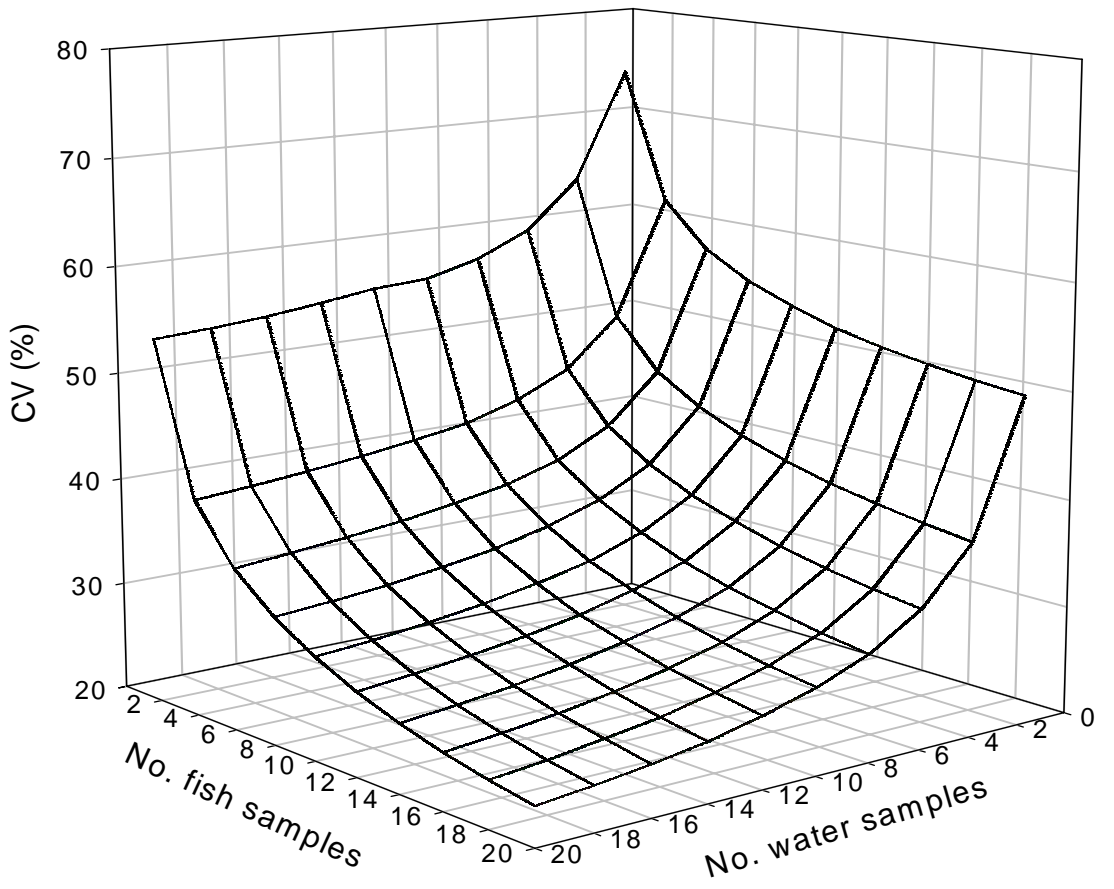

Figure 8. Effects of number of fish samples and number of water samples on largemouth bass BAF coefficient of variation (CV). CVs were calculated by resampling. 


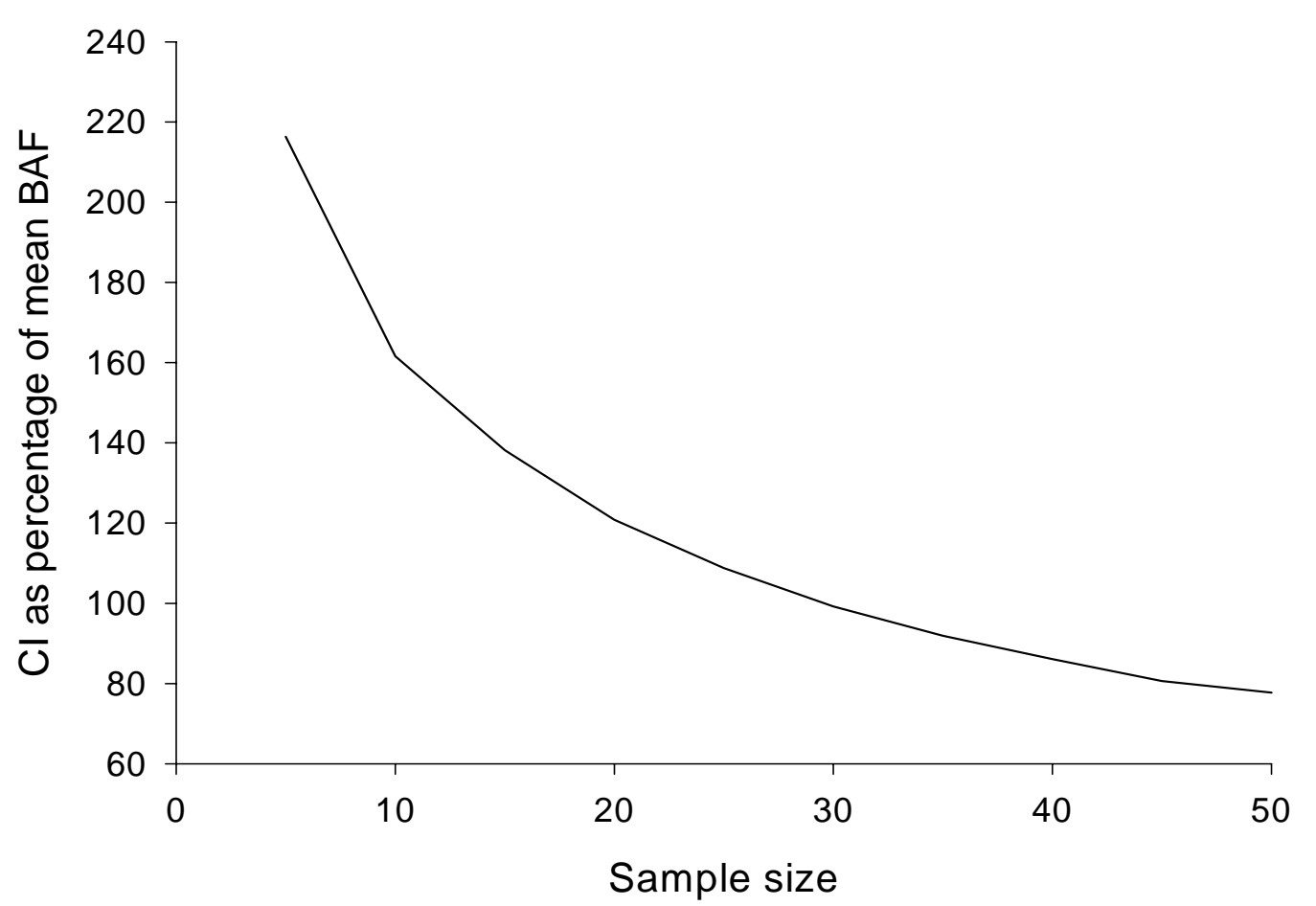

Figure 9. Relationship between sample size and the 95\% confidence interval (expressed as a percentage of the mean) for largemouth bass bioaccumulation factors (BAFs). Sample size refers to number of fish samples and number of water samples (e.g., 10 indicates 10 fish samples and 10 water samples). Confidence intervals were calculated by resampling.

tissue and water concentration averages. This bias was minimal with larger samples which reduced the leverage of atypical data points.

\section{Discussion}

The Savannah River BAFs can be compared to the default EPA (1997c) BAFs intended for use when site specific data are lacking. For piscivorous fish, such as largemouth bass (trophic level four), the default BAF for dissolved methylmercury and total mercury in fish $\left(6.8 \times 10^{6}\right.$, USEPA 1997c) was approximately twice as high as the overall average Savannah River BAF $\left(3.7 \times 10^{6}\right)$. For invertebrate-consuming fish (trophic level three), such as sunfish, the default BAF $\left(1.6 \times 10^{6}\right.$, USEPA 1997c) agreed with overall average Savannah River BAF $\left(1.4 \times 10^{6}\right)$. White catfish, which feed largely on invertebrates in the Savannah River but also consume some fish, had an average BAF $\left(2.5 \times 10^{6}\right)$ slightly higher than the EPA default BAF for trophic level three fish. The difference between the EPA default BAF and the BAF for Savannah River largemouth bass indicates the desirability of using site specific BAFs when possible. However, given the physical, chemical, and biological differences between northern lakes, from which the EPA default values are largely derived, and the Savannah River, differences between default and actual BAFs are not as great as might be expected.

Savannah River BAFs varied more within taxonomic groups than between taxonomic groups. Spatial variability in fish tissue mercury levels contributed strongly to this variation. One example was the occurrence of significantly 
higher mercury levels in sunfishes from the cuts than in sunfishes from the main channel. This was associated with the occurrence of seasonally high aqueous methylmercury levels in the cuts (Figure 6). This habitat may have presented conditions favorable for methylation, particularly during the spring when elevated water levels inundated shoreline wetlands more fully (Zillioux et al. 1993). Unlike sunfishes, mercury levels in largemouth bass and white catfish did not differ between main channel and cuts, possibly because these more mobile species integrated mercury exposure across habitats. Many stream dwelling sunfishes occupy relatively small home ranges in the order of 100 linear meters (300 ft) (Berra and Gunning 1972, Gatz and Adams 1994), while largemouth bass occupy home ranges in excess of $500 \mathrm{~m}$ (1600 ft) in the Savannah River (unpublished data) and exhibit considerable movement between the main channel and tributary streams (Jones 2001). Although white catfish movements have not been well documented, channel catfish Ictalurus punctatus range up to $5 \mathrm{~km}(3 \mathrm{mi})$ in rivers and move between main river channels, tributary streams, and oxbow lakes (Dames and Coon 1989, Flotemersch et al. 1997).

The most striking spatial difference in fish tissue mercury levels was the significant trend in all taxa of increasing mercury levels in a downstream direction. Spatial differences in walleye Stizostedion vitreum from a Columbia River reservoir have been attributed to local differences in the physical and chemical environment that affected mercury bioavailability (Munn and Short 1997). Proximity to anthropogenic sources of mercury pollution have also been linked to spatial differences in fish tissue mercury levels in a Virginia River (Hildebrand et al. 1976) and Florida estuaries (Strom and Graves 2001), although there were no obvious large mercury discharges in the Savannah River during this study. Likely sources of methylmercury to the Savannah River are wetlands associated with the river since wetlands are known to support methylmercury production (Zillioux et al. 1993). A number of large wetland draining streams in the middle and lower river may add methylmercury to the Savannah River and contribute to mercury in fish. Further studies will be needed to explain these patterns more fully.

Like mercury levels in Savannah River fish, methylmercury levels in Savannah River water were highly variable. Significant differences occurred over time, with methylmercury concentrations peaking during the spring. This pattern was probably related to seasonal differences in the activity of methylating bacteria associated with temperature, water quality, water level, or other factors. Aqueous methylmercury concentrations have shown seasonality in other studies, peaking in July in the northern Florida Everglades (Hurley et al. 1998a) and increasing in the fall in Wisconsin Lakes (Watras et al. 1995b). Seasonal changes in Savannah River aqueous methylmercury may have affected mercury levels in largemouth bass, which also increased in spring (although other taxa did not show this pattern). Seasonal variation in largemouth bass mercury levels, as a possible consequence of changes in methylmercury intake, has been reported from Oregon reservoirs (Park and Curtis 1997).

In summary, mercury levels in Savannah River fish depended on fish size, location, season, and, in the case of sunfishes, whether fish were collected from the river or the cuts. Variability in aqueous mercury levels could not be investigated as thoroughly as in fish because of limited sampling; however, season had an important effect and possibly habitat, as well. These sources of variation resulted in taxa-specific mercury BAFs that varied by factors of three to eight (depending upon taxa) for the $118 \mathrm{~km}(73 \mathrm{mi})$ reach of the Savannah River under study. There was also considerable sampling uncertainty in both fish tissue and aqueous mercury concentrations likely resulting from analytical error, individual metabolic differences, and other unidentified factors. Because water quality targets calculated with the EPA's human health based methodology for mercury are inversely and linearly dependent upon BAFs (USEPA 1997c), commensurate variation can be expected in water quality targets, in TMDLs derived from water quality targets, and in waste load allocations derived from TMDLs.

Savannah River data indicated the importance of sampling extensively in time and space for both fish tissue and aqueous mercury concentrations to produce accurate, representative BAFs in rivers. This includes sampling throughout the reach that the BAF will represent, sampling in different habitats that may vary in methylmercury production, and sampling seasonally. Another necessity is to collect large numbers of fish and water samples to maximize precision and avoid potentially large BAF variations related to unexplained sampling variance. Approximately 50 fish tissue and aqueous mercury samples were needed to stabilize BAF variability in this study. Even with this sample size, the $95 \%$ confidence interval for the overall average largemouth bass BAF was $78 \%$ of the mean, suggesting that BAFs are characterized by considerable intrinsic variability and difficult to summarize in a single number. 


\section{Effects of Tributary Stream Methylmercury on Mercury Levels in Savannah River Asiatic Clams}

\section{Introduction}

Mercury levels in many northern hemisphere aquatic ecosystems are strongly influenced by the atmospheric deposition of mercury in the surrounding watershed (Mierle 1990, Fitzgerald et al. 1991). Although much of this mercury may be retained in terrestrial soils (Nater and Grigal 1992), some is conveyed to surface and subsurface waters where it is bacterially converted to methylmercury (Gilmour et al. 1992). Wetland ecosystems are particularly efficient at producing methylmercury because they provide conditions that support methylating bacteria (Francis et al. 1998). Studies in northern lakes and rivers show that methylmercury produced in wetlands can be transported by surface flow to other water bodies where it contributes to total methylmercury loading (St. Louis et al. 1994, Hurley et al. 1995, Hurley et al. 1998b).

Many major rivers in the coastal plain of South Carolina have fish consumption advisories as a result of mercury contamination. This region has substantial atmospheric mercury deposition (USEPA 1997c) and many wetlands that are drained by small tributaries into larger rivers. The possible significance of methylmercury conveyed to rivers by such tributaries has not been investigated. A simple way of evaluating the influence of tributary mercury on river biota is to compare mercury levels in biota residing in the plumes where tributaries discharge into rivers with biota from river reaches less strongly influenced by tributary discharge. Most studies of mercury levels in biota involve fish because of their importance in the human food chain, but the mobility of fish makes them a poor choice for this type of study. Bivalves, on the other hand, are relatively sedentary, integrate bioavailable contaminant concentrations over time, and reflect contaminant transfer from water into the food web (Cope et al. 1999, Chase et al. 2001). Studies on the Asiatic clam, Corbicula fluminea, which is widely established in United States rivers, indicate that mercury uptake is directly proportional to mercury concentrations in the water column or sediment, making Corbicula fluminea potentially useful for investigating localized differences in the bioavailability of mercury (Inza et al. 1997, Inza et al.1998).

In this study, aqueous methylmercury levels were measured at a variety of locations in the Savannah River and several of its tributaries. Mercury levels were also measured in Corbicula fluminea (hereafter referred to as Corbicula) collected from the discharge plumes of Savannah River tributary streams and from river locations not directly affected by tributary discharge. The objectives were to:

1) compare aqueous methylmercury levels between the Savannah River and its tributaries as a means of assessing the potential significance of the tributaries as sources of methylmercury,

2) determine whether stream methylmercury resulted in localized increases in tissue mercury levels in Corbicula fluminea residing in the Savannah River, and

3) determine if clams can be an effective screening tool to identify local sources of mercury in the environment.

\section{Materials and Methods}

\section{Study Area}

This study was conducted in the middle reach of the Savannah River, part of which is bordered by the SRS (Figure 10). The SRS is drained by several streams including Upper Three Runs, Beaver Dam Creek, Fourmile Branch, Steel Creek, and Lower Three Runs, which join the Savannah River between RKs 253 and 208 (RMs 157 and 129 ). Two other streams of substantial size, Brier Creek and Ebenezer Creek, are located downstream of the SRS at RKs 157 (RM 98) and 72 (RM 45), respectively. Several of the SRS streams have industrial areas in their watersheds. The other streams drain largely rural and undeveloped lands where agriculture and forestry are the major land uses.

Previous studies indicated that the portion of the Savannah River under study was slightly acidic pH (5.8-6.7) and characterized by dissolved oxygen concentrations averaging about seven to eight mg/l and conductivities averaging nearly $70 \mu \mathrm{S} / \mathrm{cm}$ (Paller et al. 1985 and 1986). The tributary streams were acidic (average pH from 5.6 to 6.6), with conductivities ranging from 20-70 $\mathrm{\mu S} / \mathrm{cm}$, and with more variable and somewhat lower dissolved oxygen concentrations than the river, occasionally declining below $3.0 \mathrm{mg} / \mathrm{l}$ (Paller et al. 1986). 


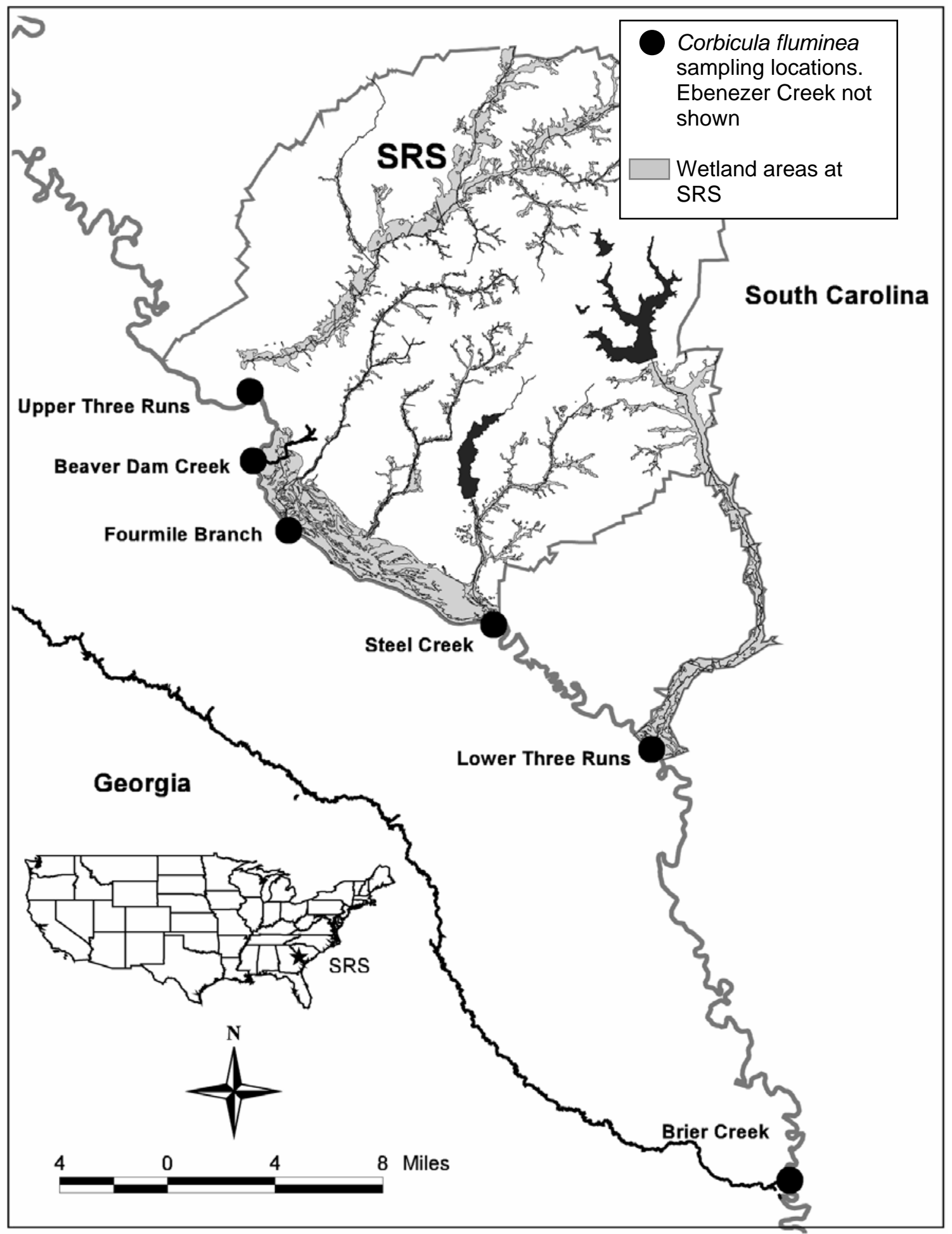

Figure 10. Map of the middle reaches of the Savannah River showing important tributary streams and the Savannah River Site. 
Approximately 99\% of the mercury loading to the Savannah River watershed is from atmospheric deposition rather than industrial discharges or other point sources (USEPA 2001b). However, Fourmile Branch may have received mercury contamination from industrial seepage basins located near its headwaters, and a small tributary of Upper Three Runs received mercury from a groundwater air stripping facility approximately $6.5 \mathrm{~km}$ from its confluence with Upper Three Runs (Halverson et al. 2002). Nevertheless, as described later, total and methylmercury levels in these streams were not exceptional compared with the other tributaries.

The five SRS streams drain extensive wetlands (Figure 10). The lower portions of Fourmile Branch, Beaver Dam Creek, and Steel Creek drain portions of a 3,900 ha (9,600 acre) floodplain swamp contiguous with the Savannah River. Each of these streams also drains an additional 600 to 900 ha (1,500 to 2,200 acres) of wetlands located along its stream corridor. Upper Three Runs and Lower Three Runs drain more extensive wetland corridors, approximately 2,600 ha (6,400 acres) each. Although wetland maps were not available for Briar and Ebenezer Creeks, exploration of the lower reaches of these streams indicated that they were connected to extensive floodplain swamps.

Field and Laboratory Methods

Water samples for mercury analysis were collected from the mouths of the five SRS streams and the Savannah River upstream of and near (within $100 \mathrm{~m}$ or $300 \mathrm{ft}$ of) each of the tributary mouths (Figure 10) on 8/28/00, 10/19/00, 11/7/00, 11/29/00, 12/5/00, 12/18/00, 4/17/01, 8/15/01, 2/25/02, 5/22/02, and 9/3/02. River samples reflected mercury levels in the river since they were taken near the middle of the river and not in the stream discharge plumes. A single sample was taken from each of the ten locations on most dates, but triplicate samples were taken from each location on 12/18/00 and 4/17/01. Water samples were taken from the mouths of Brier Creek and Ebenezer Creek and in the Savannah River just upstream of each of those creeks on 7/2/02.

Water samples were collected from approximately $25 \mathrm{~cm}$ (10 in) beneath the water surface in areas with visible flow. Samples for total mercury and methylmercury were taken by dipping and filling a pre-cleaned, marked Teflon bottle. Samples for dissolved mercury and methylmercury (taken only on 11/7/00, 11/29/00, 12/5/00, and 4/16/01) were collected by using a peristaltic pump and clean plastic tubing to force water through a 0.45 micron glass-fiber filter into pre-cleaned and marked Teflon bottles. New filters were used for each sample, and the collecting tube was thoroughly flushed with ambient water before collecting each sample. All sampling was performed with clean sample handling techniques to prevent contamination (Bloom 1995, USEPA 2001a). Samples were placed on ice and shipped the same day to a laboratory specializing in ultra-low level total mercury and methylmercury analysis using cold vapor atomic fluorescence spectroscopy (USEPA 2001a). The coefficient of variation (standard deviation / mean x 100) of triplicate samples averaged 8.3\%, indicating close correspondence.

Corbicula were collected on 6/4/02 and 6/5/02 from 12 locations: six in stream discharge plumes and six in the Savannah River just upstream of those stream mouths (Figure 10). Stream and river sample sites corresponded with the sites where aqueous mercury data were collected, as previously described, except samples were not collected at Beaver Dam Creek due to low water levels. Corbicula were taken from stream mouths at their confluence with the Savannah River or just downstream within the creek discharge plumes. Corbicula from the river were collected at least $50 \mathrm{~m}$ upstream from creek mouths and near the opposite river bank. Ten Corbicula were gathered from each site by collecting sediment with a cylindrical dredge and picking Corbicula from the sediments. The Corbicula were put in labeled, plastic zip-lock bags with water and returned to the laboratory where they were held in clean dechlorinated tap water for 12 hours to depurate. They were subsequently weighed and measured with dial calipers. All soft tissues were removed, weighed, and individually frozen.

For mercury analysis, individual Corbicula were again weighed, freeze dried to a constant weight to determine moisture content, then homogenized using a Teflon pestle in a polyethylene vial. Subsamples from each individual were analyzed for total mercury by thermal decomposition, gold amalgamation, and atomic absorption detection (EPA method 7473). All Corbicula mercury concentrations were expressed on a wet-weight basis.

More details on the methods can be found in Paller et al.(2004).

Data Analysis

The methylmercury data collected from the five SRS streams and nearby river sample sites were analyzed using a mixed analysis of variance (ANOVA) model (Sokal and Rohlf 1995) with habitat (river vs. creek mouth) and 
sample date as treatment factors and sample site nested within habitat as a random factor. Data from Brier and Ebenezer Creeks, which were sampled only once, were excluded from this analysis. Triplicate samples collected on a single date were averaged to produce a single value. Wald-Wolfowitz tests above and below the median demonstrated that the assumption of independence was met (Sokal and Rohlf 1995). The methylmercury data did not initially meet other assumptions of ANOVA, including homogeneity of variances among samples and normality of sample distributions (Sokal and Rohlf 1995). Commonly employed transformations (e.g. log and square root) failed to rectify this problem, so the variance stabilizing transformation was calculated from the slope of the log mean - log variance regression described by Taylor (1961).

Total mercury data failed to meet the assumptions of normality and homogeneity of variance even after transformation of the data (including Taylor's (1961) transformation), so they were analyzed with the Scheirer-RayHare test, a non-parametric form of the two-way ANOVA (Sokal and Rohlf 1995). Treatment factors were habitat and sample date.

Corbicula tissue mercury data were analyzed by analysis of covariance (ANCOVA) with location (river vs. creek mouth) the categorical factor and shell length the covariate. Shell length was included because Corbicula size and tissue mercury levels were related. The model also included a third factor, sample site nested within habitat, to determine if there were significant differences between individual sample sites. A preliminary ANCOVA demonstrated that the relationship between Corbicula size and tissue mercury levels was not affected by habitat or site, thus satisfying the requirement for homogeneity of slopes (Sokal and Rohlf 1995). Eight small Corbicula (shell length less than $15.2 \mathrm{~mm}$ or $0.60 \mathrm{in}$ ) had total mercury concentrations below the detection limit $(0.22 \mathrm{ng} / \mathrm{g})$. Because of the uncertainty associated with mercury levels in small Corbicula, all specimens less than $15.2 \mathrm{~mm}$ (0.60 in) in shell length (11 in total) were eliminated leaving a total sample size of 112. Mercury data were log10 transformed to satisfy statistical assumptions of normality and homogeneity of variance.

All statistical results were considered significant at $\mathrm{P}<0.05$. Statistical analyses were conducted with Systat (SPSS 1997). More details on the data analysis can be found in Paller et al.(2004).

\section{Results}

ANOVA of the SRS tributary and river methylmercury data indicated that the difference in aqueous methylmercury concentration between creek mouths and river was highly significant $(\mathrm{P}<0.001)$, as were differences between individual sample sites within habitats $(\mathrm{P}=0.003)$, differences between sample dates $(\mathrm{P}<0.001)$, and the interaction between habitat and sample date $(\mathrm{P}=0.005)$. The interaction was significant because the difference in methylmercury concentration between creek mouths and river was greater on some dates than others; however, methylmercury concentrations were at least slightly higher in the creek mouths on all sample dates (Figure 11). The average methylmercury concentration in the creek mouths $(0.170 \mathrm{ng} / \mathrm{l})$ was nearly twice as high as in the river $(0.085 \mathrm{ng} / \mathrm{l})$, and the creeks had higher percentages of methylmercury (average of 6.5\%) than the river (average of 3.4\%). Among creek mouth locations, the highest levels of methylmercury were in Steel Creek and Lower Three Runs (Figure 12). Methylmercury levels measured on a single date in the mouths of Brier and Ebenezer Creeks (0.255 $\mathrm{ng} / \mathrm{l}$ and $0.118 \mathrm{ng} / \mathrm{l}$, respectively) were comparable to the average methylmercury levels in the SRS tributaries (Figure 12). There was a general correspondence between methylmercury levels in the river and creek mouths as indicated by a significant positive correlation between average methylmercury in each habitat over time ( $\mathrm{r}=0.67$, $\mathrm{P}=0.026, \mathrm{n}=11$ ) (Figure 11).

Unlike the methylmercury ANOVA, the only significant term in the ANOVA for total mercury was the interaction between sample date and habitat $(\mathrm{P}=0.030)$, indicating that total mercury concentrations were sometimes higher in the creek mouths and sometimes in the river (Figure 11). Average total mercury levels differed little between the creek mouths $(2.98 \mathrm{ng} / \mathrm{l})$ and the river $(2.59 \mathrm{ng} / \mathrm{l})$. An analysis based on all of the water samples indicated that total mercury and methylmercury levels were significantly $(\mathrm{P}<0.001)$ but moderately correlated $(\mathrm{r}=0.54, \mathrm{n}=109)$. 

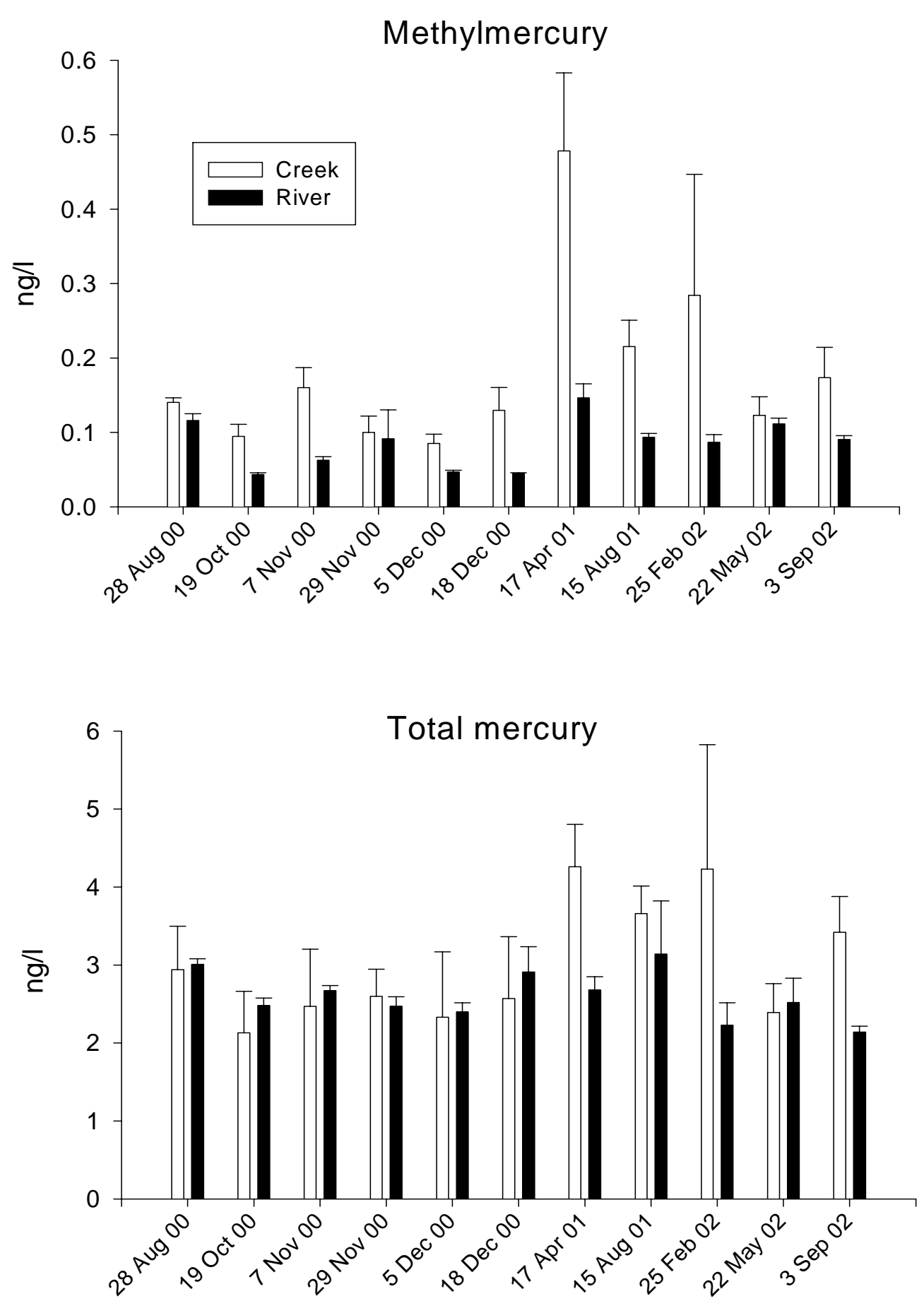

Figure 11. Average aqueous methylmercury and total mercury levels in the Savannah River and the five SRS Savannah River tributary creeks on 11 sample dates. Error bars represent standard errors. 


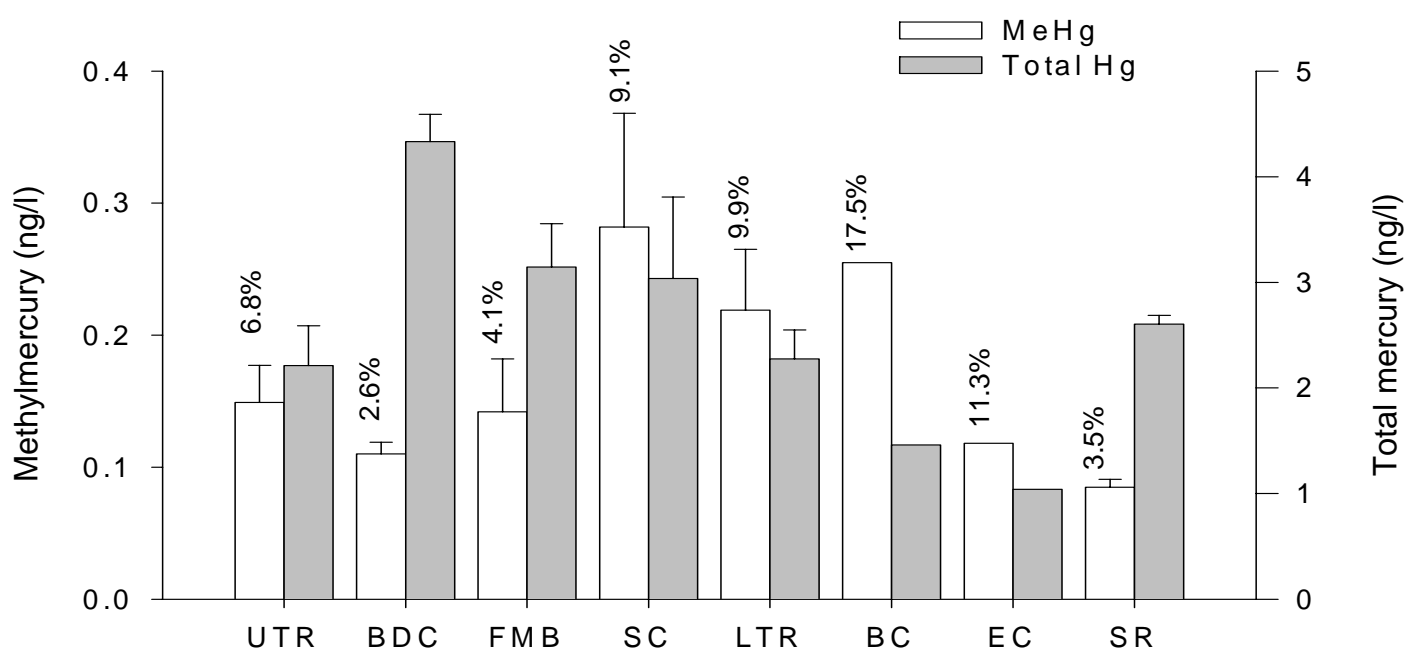

Figure 12. Average aqueous methylmercury and total mercury levels, and percentages of total mercury that were methylmercury in the Savannah River (SR) and seven streams: Upper Three Runs (UTR), Beaver Dam Creek (BDC), Fourmile Branch (FMB), Steel Creek (SC), Lower Three Runs (LTR), Brier Creek (BC), and Ebenezer Creek (EC). Error bars represent standard errors.

An average of $72 \%$ of the methylmercury was dissolved, based on filtered/unfiltered samples collected on four dates. There was little difference between the stream and the river habitats in this respect (means of $71.8 \%$ and 72.9\%, respectively). However, there was considerable difference between individual streams, with the percentage of dissolved methylmercury averaging 49\% in Beaver Dam Creek, 65\% in Upper Three Runs, 80\% in Fourmile Branch, $90 \%$ in Lower Three Runs, and $71 \%$ in Steel Creek $(\mathrm{P}<0.001$, one-way ANOVA). Somewhat less of the total mercury was dissolved than the methylmercury and, like methylmercury, there was little average difference in dissolved total mercury percentages between the river (49.1\%) and the streams (49.3\%) but significant differences between individual streams $(\mathrm{P}<0.001)$.

ANCOVA indicated that mercury levels in Corbicula were significantly related to Corbicula size $(\mathrm{P}<0.001)$, that they differed significantly between river and creeks $(\mathrm{P}<0.001)$, and that they differed significantly among sample sites within habitats $(\mathrm{P}<0.001)$ (Figures 13 and 14). Geometric mean mercury levels normalized to an average shell length of $24.1 \mathrm{~mm}$ were $44 \mathrm{ng} / \mathrm{g}$ wet weight for the creek mouths and $17 \mathrm{ng} / \mathrm{g}$ wet weight for the river sites. Corbicula mercury levels differed among streams, with the highest levels occurring in Corbicula from Upper Three Runs (Figure 14). Average Corbicula tissue mercury levels in the streams were not correlated with average aqueous methylmercury levels $(r=0.22, n=6)$ or total mercury levels $(r=0.13, n=6)$ in the streams.

\section{Discussion}

Total and methylmercury concentrations in the Savannah River were within the range measured in Wisconsin rivers draining wetland and forested watersheds (Hurley et al. 1995), but much lower than total mercury levels (1.3 $\mu \mathrm{g} / \mathrm{l}) \mathrm{in}$ a Tennessee stream that received mercury discharge from an industrial facility (Southworth et al. 1995). Except for rivers with significant point sources of mercury, most methylmercury in rivers is derived from nonpoint sources in the watershed (Balogh et al. 1998), especially the deposition of atmospheric mercury released by burning coal and other industrial activities that volatilize mercury (Lacerda and Fitzgerald 2001). In the Savannah River approximately 99\% of the mercury load is atmospheric (USEPA 2001b). Wetlands are especially efficient at converting mercury to methylmercury, possibly because they retain mercury well and provide conditions (low dissolved oxygen levels and high levels of organic matter) that favor the sulfate-reducing bacteria involved in methylation (Regnell 1994, Francis et al. 1998). As a result, methylmercury export is generally greater from wetland watersheds than from upland watersheds (St. Louis et al. 1994), and methylmercury levels are higher in rivers with a high proportion of wetlands in their watersheds (Hurley et al. 1995). 


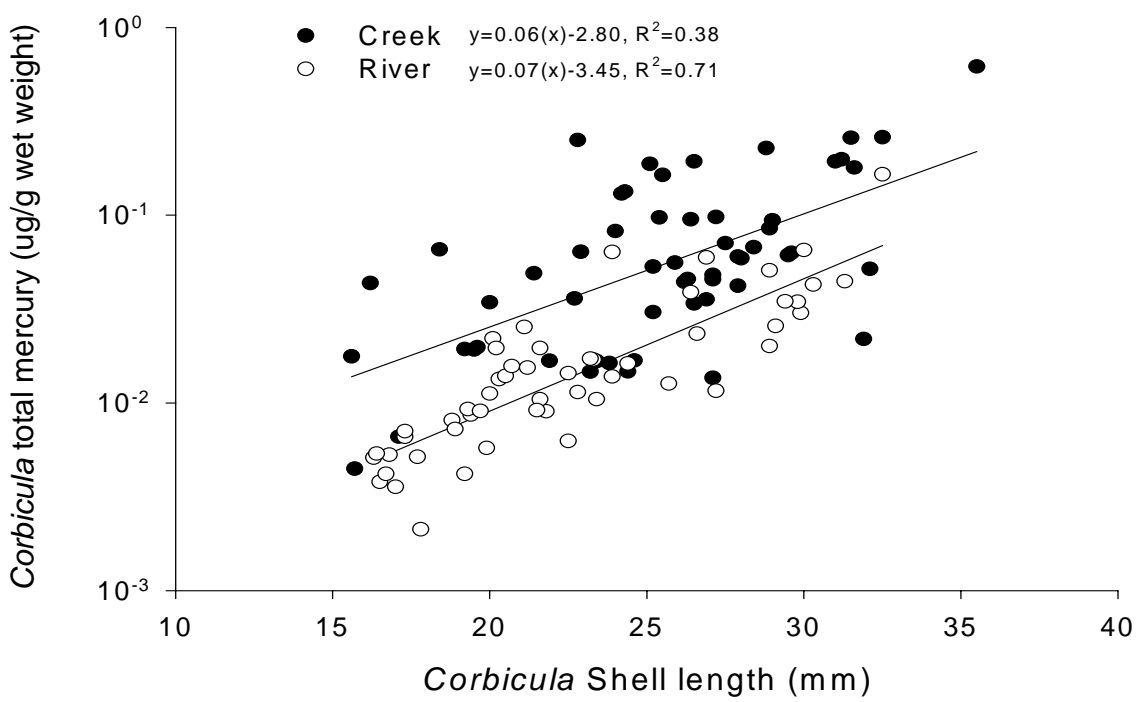

Figure 13. Relationship between mercury concentration and shell length in Corbicula fluminea collected from the Savannah River and several Savannah River tributaries.

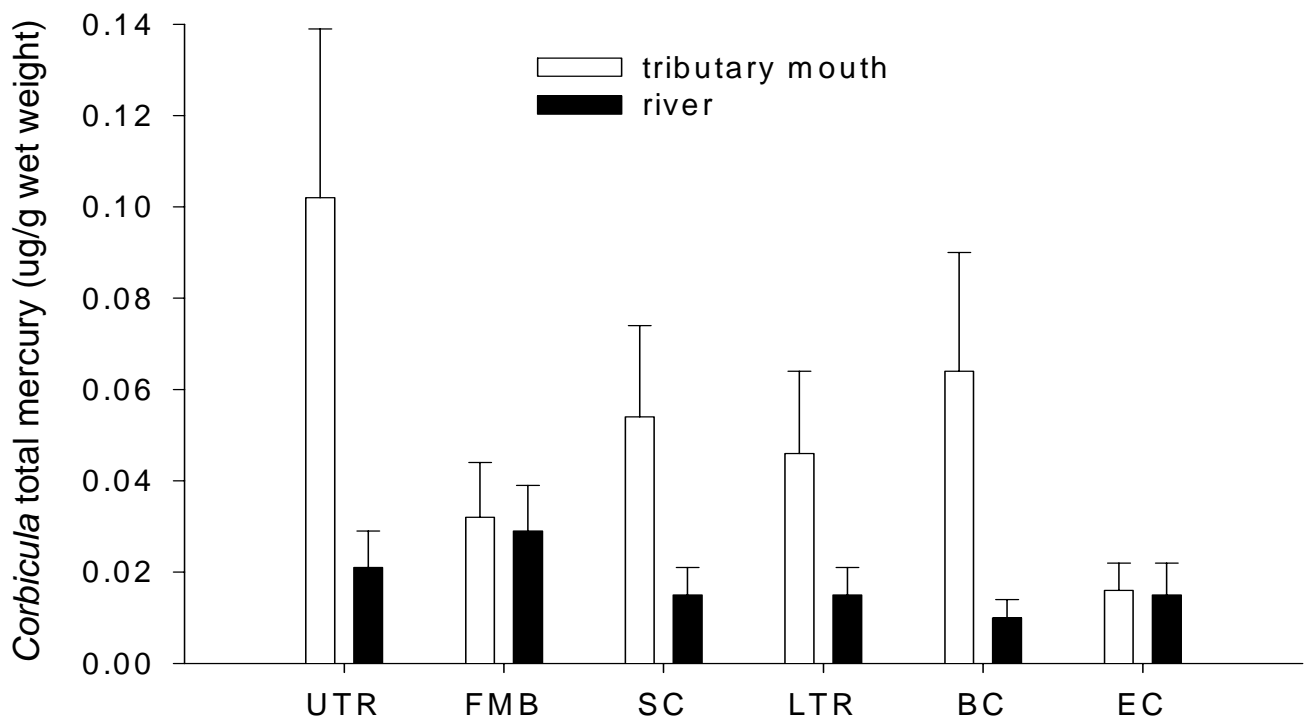

Figure 14. Geometric mean mercury levels in Corbicula fluminea collected from six Savannah River tributaries (Upper Three Runs, UTR; Beaver Dam Creek, BDC; Fourmile Branch, FMB; Steel Creek, SC; Lower Three Runs, LTR; Brier Creek, BC; Ebenezer Creek, EC) and six Savannah River sites located just upstream from each of the tributaries. Error bars represent 95\% confidence intervals. 
The streams had significantly higher aqueous methylmercury concentrations than the Savannah River (Figure 12). However, total mercury concentrations did not generally differ between the river and its tributaries (Figure 12), suggesting that differences in the amount of inorganic mercury available for methylation were not responsible for the difference in methylmercury concentration between river and streams. The most likely reason for higher methylmercury levels in the streams was that the streams supported more favorable environments for methylation. All of the streams in this study drained extensive wetlands that would be expected to support comparatively high rates of methylation. The stream water also tended to be relatively acidic, a condition often associated with increased methylation (Gilmour and Henry 1991).

Methylmercury concentrations and percentages of methylmercury varied among the streams (Figure 12) suggesting variations in methylation efficiency among streams. These variations were unlikely to be due to differences in total mercury. Beaver Dam Creek, the stream with the highest average total mercury concentration, had the lowest average methylmercury concentration. The two streams with the highest concentrations and percentages of methylmercury, Steel Creek and Lower Three Runs, had 400 to 1,000 ha (1,000 to 2,500 acre) reservoirs in their upper reaches that may have directly contributed methylmercury or influenced in-stream methylation rates by affecting stream water chemistry (e.g., dissolved carbon levels).

Methylmercury levels varied among streams, but all streams had at least slightly higher average methylmercury levels than the river (Figure 12). The influence of this tributary methylmercury on the total methylmercury load in the Savannah River is difficult to determine. Correlation between mercury levels in the stream mouths and the river suggests that the streams are transporting methylmercury to the river. However, another explanation could be that parallel patterns of methylmercury in the streams and river were due to unmeasured factors affecting both habitats similarly. United States Geological Survey (USGS) stream and river discharge records from 1990 to 2000 indicated that total discharge from the streams in this study (excluding Ebenezer Creek, for which data were unavailable) composed about $13 \%$ of the discharge in the Savannah River, suggesting that mercury transported from them alone constituted a comparatively small proportion of the total Savannah River mercury load. However, this comparison did not include the many other Savannah River tributaries not studied.

Stream discharge appeared to create localized methylmercury "hotspots" that raised mercury levels in Corbicula residing within the stream discharge plumes. Soft tissue mercury levels were about 2.5 times higher in Corbicula from the stream discharge plumes than in Corbicula from the Savannah River upstream from the plumes. This difference was likely a direct consequence of exposure to elevated methylmercury levels in the stream discharge. Laboratory studies have demonstrated that Corbicula rapidly bioaccumulates methylmercury to a much greater extent than inorganic mercury and that bioaccumulation is proportional to the methylmercury concentration in the water column or sediment (Inza et al. 1997).

Mercury levels were consistently higher in stream Corbicula than in river Corbicula; however, stream Corbicula mercury levels and stream aqueous methylmercury levels were not significantly correlated. Because Corbicula are filter feeders (Inza et al. 1997), their methylmercury intake may be more closely related to particulate (filterable) methylmercury than to dissolved methylmercury. Lower Three Runs, with the highest Corbicula mercury levels, also had the highest proportion of filterable methylmercury in its discharge (Figure 12), supporting this possibility. However, Corbicula can also ingest periphyton growing on the sediments, and may be able to directly accumulate methylmercury from the water (Inza et al. 1997). Therefore, methylmercury uptake by Corbicula may not be determined solely by the methylmercury concentration in the water but also by the form of the methylmercury (particulate versus dissolved) and by the relative predominance of several possible modes of methylmercury uptake.

The occurrence of relatively high levels of mercury in Corbicula from the stream mouths suggests the possibility that other organisms from these habitats may also have comparatively high mercury levels. This might apply to fishes with limited movement, such as sunfish, which occupy relatively small home ranges (100 linear $\mathrm{m}$ or about $300 \mathrm{ft}$, Gatz and Adams 1994). Even relatively mobile biota located further upstream in the tributaries, where there is less possibility of movement to areas with lower methylmercury levels, might have elevated mercury levels. Because human exposure to methylmercury occurs primarily through the consumption of contaminated fish (USEPA 1997a), it is possible that consumption of fish caught in and near Savannah River tributaries could result in elevated methylmercury uptake. 
The results of this study indicated that tributaries in the middle reaches of the Savannah River appeared to be sources of elevated methylmercury that can result in localized increases in mercury levels in Corbicula and presumably other biota. Elevated methylmercury levels in the tributaries may be associated with the drainage of wetland habitats and water chemistry characteristics that favor methylmercury production. More intensive research will be needed to better understand methylmercury production in the tributaries, the impact of tributary discharge on methylmercury level in the river and river biota, and the possibility of elevated tributary methylmercury levels in other river systems. 


\section{Atmospheric Deposition of Mercury via Rainfall}

\section{Introduction}

The EPA concluded in their Mercury Study Report to Congress that a plausible link exists between past and present, human-caused, atmospheric emissions of mercury in the United States and increased concentrations of mercury found in the environment and freshwater fish (USEPA 1997a). The impact of the atmospheric deposition rate of mercury on water quality in South Carolina and Georgia is discussed here.

Baseline estimates for deposition utilized results from the national RELMAP model that was developed and presented in the 1997 EPA Mercury Report to Congress (USEPA 1997c). This national scale modeling provided insight on the variation and trends of mercury deposition on a national scale. In the national study, annual wet and dry deposition was examined on a $40 \mathrm{~km} \mathrm{x} 40 \mathrm{~km}$ (25 mi x $25 \mathrm{mi}$ ) scale across the continental U.S. During development of the TMDL, EPA concluded that across the watershed, the average wet deposition rate was 12.2 $\mu \mathrm{g} / \mathrm{m}^{2}$ per year and the average dry deposition rate was $8.22 \mu \mathrm{g} / \mathrm{m}^{2}$ per year. Using the distribution of wet and dry deposition, an estimate of loading from the watershed to the Savannah River was simulated using a Watershed Characterization System. This assessment determined that $58.8 \mathrm{~kg} / \mathrm{yr}$ of mercury was being deposited from sources within the "airshed" and that proposed implementations of the Clean Air Act would reduce this number by 38\%$48 \%$ by 2010 . To validate these proposed reductions, systematic measurements of mercury in precipitation were necessary.

Although a significant focus on mercury in the environment is placed on concentration, the most important property associated with the environmental transport is deposition rate, which combines the concentration observed in precipitation with rainfall quantity. This mechanism serves as the primary transport process for mercury to most aquatic systems (Mason et al. 1994; Mason et al. 1997). In this mechanism deposition to the aquatic system occurs either by direct deposition to the water surface or as runoff from the watershed (Mason et al. 1999). Recent investigators speculate that mercury provided via direct deposition is more biologically available than that transported via runoff/groundwater (Mason et al. 2000).

\section{Materials and Methods}

To obtain a better understanding of the atmospheric deposition of mercury and to support issues within the TMDL, SRS installed a monitoring station as part of the national Mercury Deposition Network (MDN), which is a part of the National Atmospheric Deposition Program (NADP). The objective of the MDN is to develop a national database of weekly concentrations of total mercury in precipitation and to determine the seasonal and annual flux of total mercury in wet deposition. The data is used to develop information on spatial and seasonal trends in mercury deposited to surface waters, forested watersheds, and other sensitive receptors. The data collected under this program may be used to direct current and future mercury policies and modeling efforts. The MDN has been recognized as a critical tool for assessing the effectiveness of $\mathrm{Hg}$ controls and lowered emission limits (National Atmospheric Deposition Program (NRSP-3)/Mercury Deposition Network 2003). Figure 15 shows the distribution of MDN sampling stations in the United States and Canada.

Station SC03 began operation on January 29, 2001. In addition to the SRS station (SC03), three additional MDN stations were active in the states of Georgia and South Carolina (Figure 16) during this study. These stations were located at the Congaree Swamp National Monument southeast of Columbia, South Carolina (SC19); at the Okefenokee National Wildlife Refuge south of Waycross, Georgia (GA09); and at Yorkville, Georgia near Rome (GA40). The stations at Congaree Swamp National Monument (SC19) and at the Okefenokee National Wildlife Refuge (GA09) began operating in the 1990s. These records provide insight on seasonal variations and annual flux of total mercury in wet deposition across the region. The Rome station (GA40) began operations on June 13, 2000.

The MDN uses standardized methods for collection, analyses, and evaluation of total wet mercury deposition. Weekly precipitation samples are collected at MDN sites in a modified Aerochem Metrics model 301 collector that is interfaced with a Belfort universal recording rain gauge. The "wet-side" sampling glassware is removed from the collector weekly and mailed to the Hg Analytical Laboratory at Frontier Geosciences in Seattle, WA for analysis by cold vapor atomic fluorescence (Method 1631). 


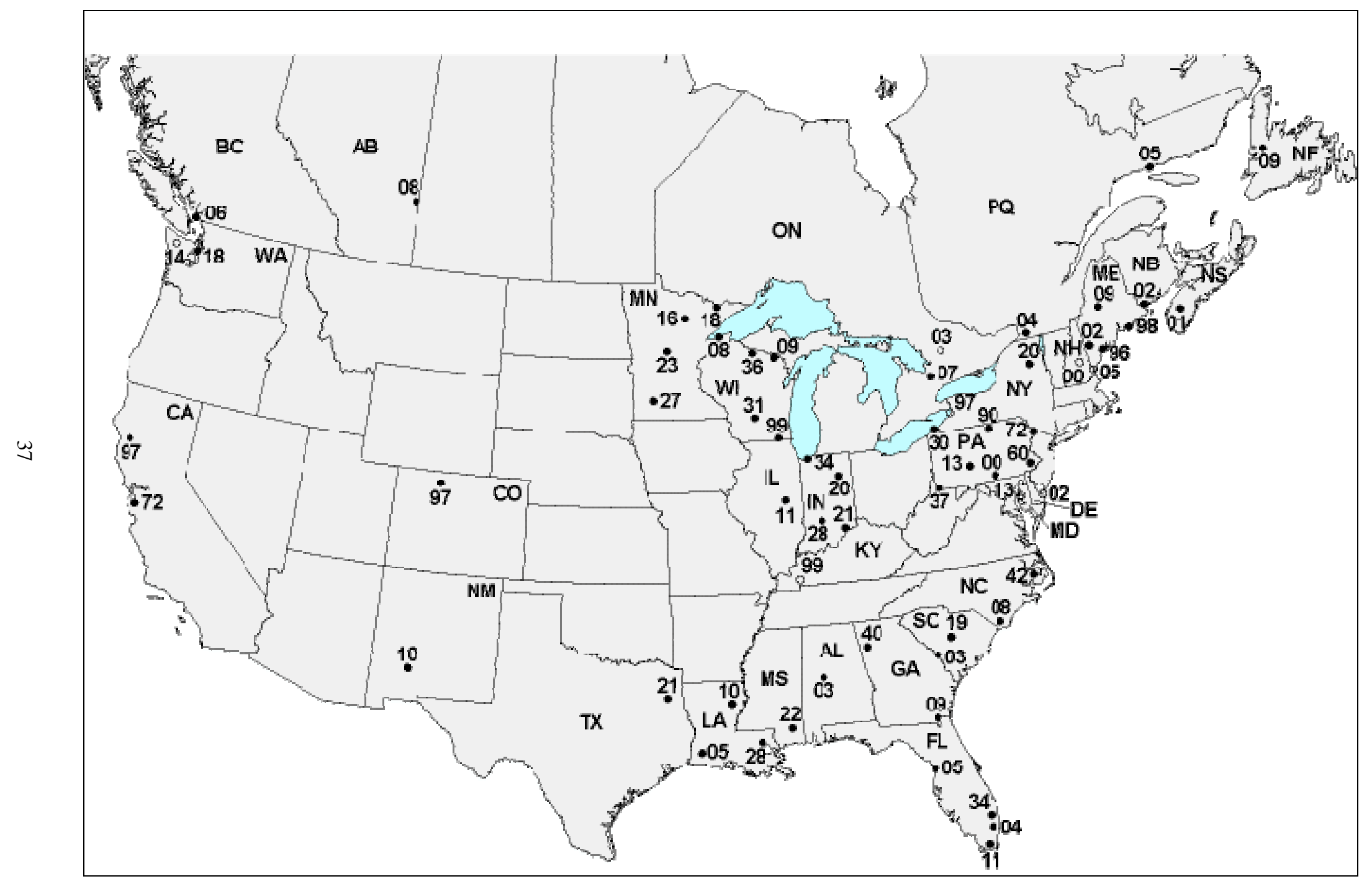

Figure 15. Sampling stations in the United States and Canada that constituted the Mercury Deposition Network of the National Atmospheric Deposition Program during this study. 


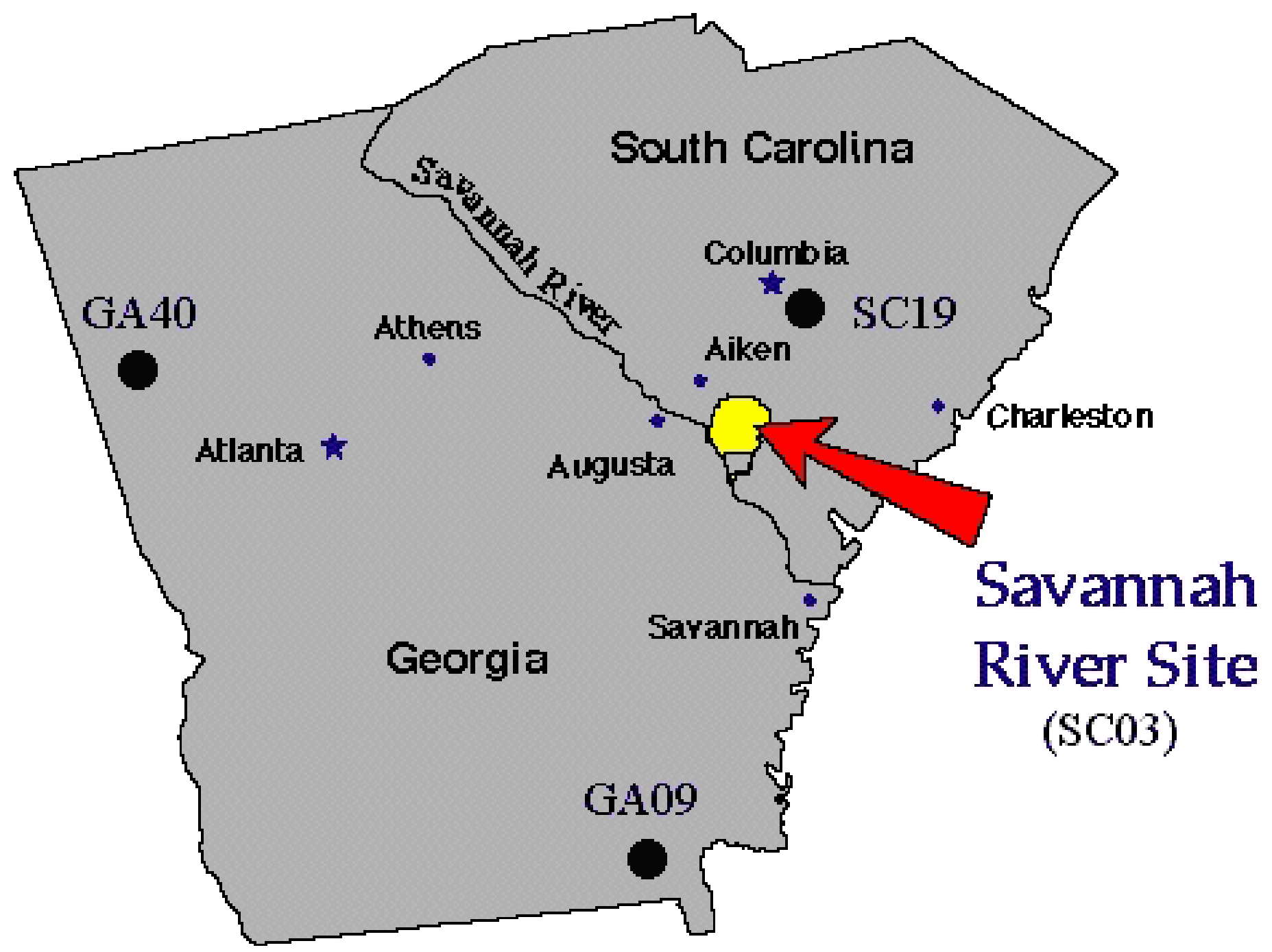

Figure 16. Mercury Deposition Network sampling stations located in Georgia and South Carolina during this study. Station sponsors were the U.S. Fish and Wildlife Service (GA09), The Southern Company (GA40), Westinghouse Savannah River Company (SC03), and South Carolina Division of Air Quality (SC19). 


\section{Results}

Between January 2001 and January 2003, the Savannah River National Laboratory (then the Savannah River Technology Center) operated and maintained Station SC03 at the SRS as part of the MDN. During this period weekly measurements of concentration and deposition of total mercury in precipitation were obtained (Table 12). For this period, the volume weighted average concentration $(n=75)$ of total mercury observed in precipitation was $12.56 \mathrm{ng} / \mathrm{l}$, and the average weekly rate of mercury deposition ( $\mathrm{n}=94$ ) was $238.05 \mathrm{ng} / \mathrm{m}^{2}$ per week.

Between November 2001 and January 2003, forty-five of the weekly precipitation samples were also analyzed for methylmercury by the MDN contract laboratory, Frontier Geosciences, Inc. of Seattle, Washington. These results are presented in Table 12 and are summarized in Table 13. As presented in these tables, methylmercury concentrations ranged from $0.003 \mathrm{ng} / \mathrm{l}$ to $1.621 \mathrm{ng} / \mathrm{l}$, with weekly deposition rates ranging from 0.0 to $17.75 \mathrm{ng} / \mathrm{m}^{2}$ methylmercury. The ratio of methyl to total mercury from these samples indicated that less than $1.0 \%(\mathrm{p}=0.99)$ of the total mercury deposited was of the methyl species at Station SC03. This suggested that methylation occurred at some other location in the mercury cycle, specifically after deposition and prior to accumulation within fish.

Deposition data from the four MDN stations located in Georgia and South Carolina were combined to evaluate annual concentration and deposition. Using data collected from stations GA09, GA40, SC03, and SC19 for the period between January 1996 and December $2002(\mathrm{n}=701)$, the volume weighted average concentration of total mercury in precipitation was observed to be $11.00 \mathrm{ng} / \mathrm{l}$. Combining precipitation volume with the measured concentrations reported from the four southeastern stations, the annual flux of total mercury in wet deposition across the region was determined. For the period of record the average wet deposition rate of total mercury was 224.7 $\mathrm{ng} / \mathrm{m}^{2}$ per week ( $\mathrm{n}=859$ ), with a median value of $111.9 \mathrm{ng} / \mathrm{m}^{2}$ per week. This is consistent with EPA's estimate that within the Savannah River watershed the average wet deposition of total mercury is $235 \mathrm{ng} / \mathrm{m}^{2}$ per week (presented as $12.2 \mathrm{\mu g} / \mathrm{m}^{2}$ per year) (USEPA 2001b, Appendix A). The maximum weekly deposition observed was 2,625 ng/m².

\section{Discussion}

The combined dataset from Georgia and South Carolina was investigated using two-way ANOVA with factors of station and month. This analysis indicated a significant variability in monthly deposition ( $<0.01)$, independent of station ( $\mathrm{p}=0.92)$. The monthly variation of total mercury in precipitation is presented in Figure 17. As indicated in this figure the measured concentration ranged between $0.3 \mathrm{ng} / \mathrm{l}$ and $275.7 \mathrm{ng} / \mathrm{l}$. As indicated in Figure 17, variation in the monthly median concentration was observed, ranging from 36\% below the annual median in March to 55\% above the annual median in August. The variation of total mercury present in rainfall indicated that total mercury concentrations were below the annual median in the winter and increased through the spring, reaching a maximum in late summer, and then rapidly declined below the annual median in the early fall.

The monthly variation of weekly deposition rate of mercury in precipitation is presented in Figure 18 and Table 14. Variation in the weekly wet deposition rate was observed with the monthly median. The general trend indicated nominal weekly deposition at the annual rate in winter that increased slightly through the spring, reached a

maximum in late summer and then rapidly declined below the annual median in the fall. These observations contradicted statements made in the TMDL suggesting that the highest deposition occurs in winter and spring. (USEPA 2001b) The seasonal observations were consistent with the observations of wet deposition in the Chesapeake Bay (Mason et al. 2000), in that higher relative concentration and higher rainfall in summer enhanced the overall flux in summer months compared to other periods. 
Table 12. Analytical concentration and deposition results for total and methylmercury for samples collected from November 2001 to January 2003 at Station SC03 as part of the Mercury Deposition Network.

\begin{tabular}{|c|c|c|c|c|c|}
\hline End Date & $\begin{array}{c}\text { Concentration } \\
\text { Methyl-Hg } \\
\text { (ng/L) }\end{array}$ & $\begin{array}{c}\text { Methyl-Hg } \\
\text { Deposition } \\
\text { (ng MHg/m²) }\end{array}$ & $\begin{array}{c}\text { Concentration } \\
\text { Total-Hg } \\
\text { (ng/L) }\end{array}$ & $\begin{array}{c}\text { Total-Hg } \\
\text { Deposition } \\
\left(\mathbf{n g ~ M H g} / \mathrm{m}^{2}\right)\end{array}$ & Methyl: Total \\
\hline $11 / 27 / 01$ & $<0.007$ & $<0.1$ & 12.59 & 227.0 & $0.06 \%$ \\
\hline 12/11/01 & 0.017 & 0.10 & 9.47 & 54.1 & $0.18 \%$ \\
\hline 12/18/01 & 0.039 & 0.23 & 12.96 & 74.2 & $0.30 \%$ \\
\hline 01/08/02 & 0.087 & 2.53 & 3.48 & 102.2 & $2.50 \%$ \\
\hline 01/15/02 & 0.159 & 4.20 & 5.84 & 154.3 & $2.73 \%$ \\
\hline 01/22/02 & $<0.046$ & $<0.6$ & 8.91 & 90.5 & $0.52 \%$ \\
\hline 2/12/2002 & 0.004 & 0.18 & 6.03 & 294.8 & $0.06 \%$ \\
\hline $2 / 26 / 2002$ & $<0.046$ & $<0.2$ & 8.88 & 27.1 & $0.52 \%$ \\
\hline 3/5/2002 & 0.010 & 0.28 & 3.89 & 110.5 & $0.25 \%$ \\
\hline $3 / 12 / 2002$ & 0.008 & 0.00 & 12.38 & 154.1 & $0.06 \%$ \\
\hline $3 / 19 / 2002$ & 0.010 & 0.21 & 11.61 & 238.9 & $0.09 \%$ \\
\hline $3 / 26 / 2002$ & 0.031 & 0.41 & 13.85 & 181.6 & $0.22 \%$ \\
\hline 4/2/2002 & 0.029 & 0.45 & 17.90 & 281.9 & $0.16 \%$ \\
\hline $4 / 16 / 2002$ & 0.046 & 1.89 & 5.33 & 222.8 & $0.85 \%$ \\
\hline $4 / 23 / 2002$ & 1.621 & 14.37 & 38.34 & 271.8 & $4.23 \%$ \\
\hline $4 / 30 / 2002$ & 0.057 & 0.36 & 21.22 & 119.9 & $0.27 \%$ \\
\hline 5/7/2002 & 0.124 & 1.38 & 34.03 & 380.3 & $0.36 \%$ \\
\hline $5 / 14 / 2002$ & 0.055 & 0.62 & 9.81 & 112.1 & $0.56 \%$ \\
\hline $5 / 21 / 2002$ & 0.022 & 0.27 & 6.96 & 88.3 & $0.31 \%$ \\
\hline 6/4/2002 & 0.107 & 0.92 & 33.72 & 295.5 & $0.32 \%$ \\
\hline $6 / 11 / 2002$ & $<0.003$ & $<0.0$ & 37.76 & 28.8 & $0.01 \%$ \\
\hline $6 / 18 / 2002$ & 0.019 & 0.32 & 12.85 & 215.3 & $0.15 \%$ \\
\hline $6 / 25 / 2002$ & 0.060 & 1.45 & 11.41 & 275.4 & $0.53 \%$ \\
\hline 7/2/2002 & 0.095 & 1.25 & 10.85 & 143.4 & $0.87 \%$ \\
\hline 7/9/2002 & 0.268 & 17.75 & 17.27 & 1142.5 & $1.55 \%$ \\
\hline $7 / 16 / 2002$ & 0.048 & 1.82 & 9.09 & 340.4 & $0.53 \%$ \\
\hline $7 / 23 / 2002$ & 0.090 & 3.51 & 26.11 & 1011.4 & $0.35 \%$ \\
\hline 08/06/02 & $<0.012$ & $<0.7$ & 16.97 & 469.8 & $0.07 \%$ \\
\hline 08/20/02 & 0.033 & 1.07 & 23.68 & 769.7 & $0.14 \%$ \\
\hline 08/27/02 & $<0.023$ & $<0.2$ & 27.12 & 188.0 & $0.08 \%$ \\
\hline 09/03/02 & 0.033 & 2.66 & 8.89 & 725.7 & $0.37 \%$ \\
\hline 09/17/02 & 0.009 & 0.18 & 23.74 & 455.2 & $0.04 \%$ \\
\hline $09 / 24 / 02$ & 0.011 & 0.29 & 15.06 & 380.6 & $0.08 \%$ \\
\hline 10/08/02 & 0.062 & 0.31 & 6.60 & 33.7 & $0.93 \%$ \\
\hline 10/15/02 & 0.014 & 0.31 & 12.40 & 267.8 & $0.11 \%$ \\
\hline 10/22/02 & 0.048 & 0.94 & 5.70 & 112.9 & $0.83 \%$ \\
\hline 10/29/02 & 0.091 & 2.04 & 21.10 & 474.8 & $0.43 \%$ \\
\hline $11 / 05 / 02$ & 0.478 & 3.51 & 21.20 & 156.9 & $2.25 \%$ \\
\hline 11/12/02 & $<0.033$ & $<2.0$ & 13.00 & 782.6 & $0.25 \%$ \\
\hline 11/20/02 & 0.071 & 2.60 & 4.50 & 164.7 & $1.59 \%$ \\
\hline 12/10/02 & 0.140 & 1.98 & 15.40 & 218.7 & $0.91 \%$ \\
\hline 12/17/02 & 0.070 & 2.72 & 6.50 & 253.5 & $1.07 \%$ \\
\hline 12/23/02 & $<0.020$ & $<0.3$ & 16.30 & 182.6 & $0.12 \%$ \\
\hline 12/31/02 & 0.019 & 0.60 & 10.30 & 334.8 & $0.18 \%$ \\
\hline 01/07/03 & 0.081 & 0.45 & 4.70 & 25.8 & $1.72 \%$ \\
\hline
\end{tabular}


Table 13. Summary of concentration and deposition results for total and methylmercury between January 2001 and January 2003 at Station SC03 as part of the Mercury Deposition Network.

\begin{tabular}{|c|c|c|c|c|c|}
\hline End Date & $\begin{array}{c}\text { Concentration } \\
\text { Methyl-Hg (ng/L) }\end{array}$ & $\begin{array}{c}\text { Methyl-Hg } \\
\text { Deposition } \\
\text { (ng MHg/m²) }\end{array}$ & $\begin{array}{l}\text { Concentration } \\
\text { Total-Hg (ng/L) }\end{array}$ & $\begin{array}{c}\text { Total-Hg } \\
\text { Deposition } \\
\left(\mathrm{ng} \mathrm{Hg} / \mathrm{m}^{2}\right)\end{array}$ & Methyl: Total \\
\hline Minimum & $<0.003$ & 0.00 & 3.48 & 25.8 & $0.01 \%$ \\
\hline $1^{\text {st }}$ Quartile & 0.019 & 0.27 & 8.88 & 112.9 & $0.14 \%$ \\
\hline Median & 0.046 & 0.60 & 12.40 & 218.7 & $0.32 \%$ \\
\hline $3^{\text {rd }}$ Quartile & 0.081 & 1.98 & 17.90 & 334.8 & $0.85 \%$ \\
\hline Maximum & 1.621 & 17.75 & 38.34 & 1142.5 & $4.23 \%$ \\
\hline Average & 0.097 & 1.74 & 14.57 & 280.8 & $0.66 \%$ \\
\hline
\end{tabular}




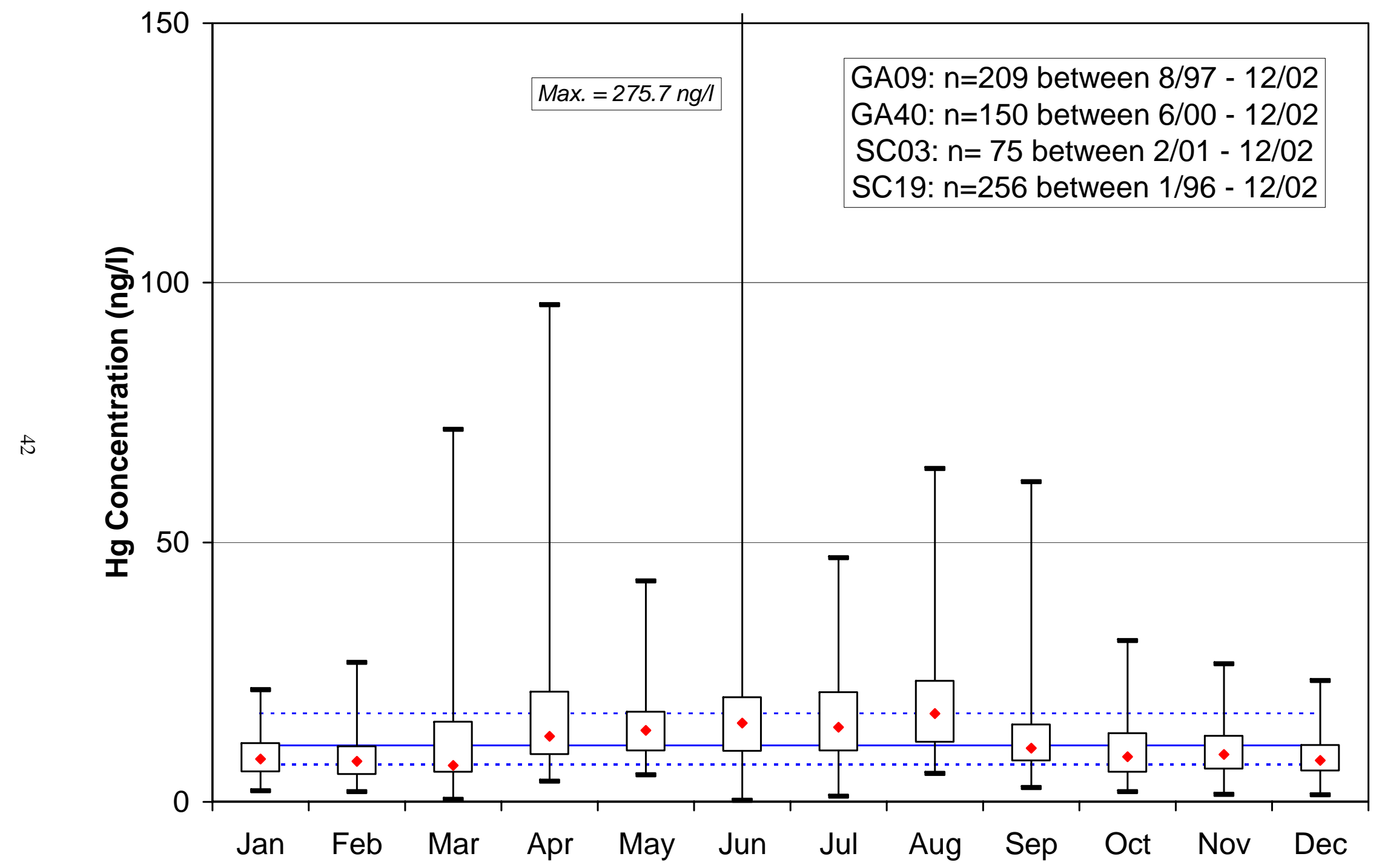

Figure 17. Annual median (solid line), $25^{\text {th }}, 75^{\text {th }}$ quartiles (dashed line) and monthly variation (box $\&$ whiskers) of total mercury concentration in precipitation for the period from January 1996 through December 2002 from NADP MDN stations located in Georgia and South Carolina (Stations GA09, GA40, SC03 and SC19). 


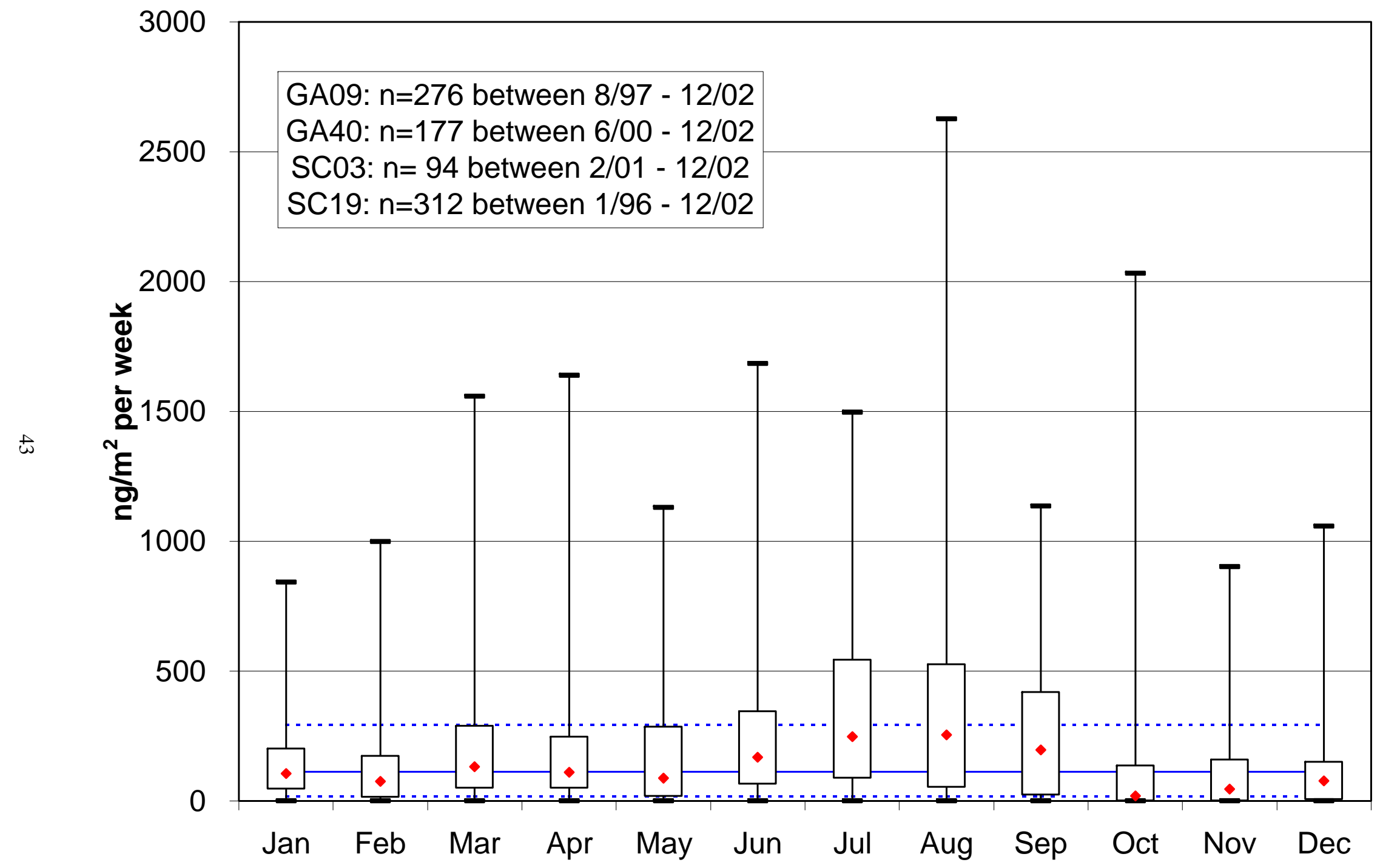

Figure 18. Annual median (solid line), $25^{\text {th }}, 75^{\text {th }}$ quartiles (dashed line) and monthly variation (box \& whiskers) of weekly deposition rate of total mercury from precipitation for the period from January 1996 through December 2002 from NADP MDN stations located in Georgia and South Carolina (Stations GA09, GA40, SC03 and SC19). 
Table 14. Summary data of total mercury concentration in precipitation and associated weekly deposition rates from January 1996 through December 2002 at NADP MDN Stations GA09 and SC19.

\begin{tabular}{|c|c|c|c|c|c|c|c|c|c|c|}
\hline & \multicolumn{5}{|c|}{ Concentration (ng/l) } & \multicolumn{5}{|c|}{ Deposition (ng/m2 per wk) } \\
\hline & Min. & 25th & 50th & 75th & Max. & Min. & 25th & 50th & 75th & Max. \\
\hline Jan & 2.10 & 5.80 & 8.25 & 11.28 & 21.60 & 0.00 & 45.02 & 104.75 & 201.13 & 841.60 \\
\hline Feb & 1.92 & 5.25 & 7.80 & 10.73 & 26.80 & 0.00 & 14.25 & 74.60 & 172.88 & 997.64 \\
\hline Mar & 0.40 & 5.70 & 7.03 & 15.45 & 71.70 & 0.00 & 49.20 & 132.22 & 289.10 & 1557.70 \\
\hline Apr & 3.95 & 9.15 & 12.66 & 21.25 & 95.70 & 0.00 & 49.39 & 110.20 & 247.95 & 1638.50 \\
\hline May & 5.20 & 9.80 & 13.80 & 17.40 & 42.50 & 0.00 & 17.30 & 88.30 & 285.70 & 1130.14 \\
\hline Jun & 0.30 & 9.75 & 15.15 & 20.20 & 275.70 & 0.00 & 64.33 & 169.25 & 344.77 & 1684.40 \\
\hline Jul & 1.03 & 9.85 & 14.34 & 21.15 & 47.00 & 0.00 & 87.55 & 248.05 & 543.03 & 1497.10 \\
\hline Aug & 5.40 & 11.45 & 17.00 & 23.35 & 64.20 & 0.00 & 53.30 & 255.00 & 527.05 & 2625.70 \\
\hline Sep & 2.70 & 7.93 & 10.35 & 14.93 & 61.63 & 0.00 & 23.63 & 196.65 & 420.08 & 1135.50 \\
\hline Oct & 1.90 & 5.70 & 8.70 & 13.20 & 31.00 & 0.00 & 0.00 & 19.85 & 136.53 & 2032.30 \\
\hline Nov & 1.40 & 6.34 & 9.15 & 12.70 & 26.60 & 0.00 & 0.00 & 46.00 & 159.65 & 901.60 \\
\hline Dec & 1.30 & 5.93 & 7.95 & 10.99 & 23.30 & 0.00 & 5.15 & 77.30 & 150.80 & 1058.71 \\
\hline Annual & 0.30 & 7.18 & 10.90 & 17.08 & 275.70 & 0.00 & 17.40 & 111.90 & 292.87 & 2625.70 \\
\hline
\end{tabular}




\section{Preliminary Mass Balance of Mercury at the Savannah River Site}

To determine the extent and significance of the site's contribution of mercury to the Savannah River, a preliminary, very simplified mass balance was performed for total mercury at the SRS. A mass balance is based on principle of conservation of mass: input must equal accumulation plus output. The amount of mercury entering the system should equal the sum of the mercury retained or chemically changed within the system and the mercury leaving the system. For the purposes of this study, the SRS system boundary was drawn to incorporate the portion of the Savannah River adjacent to the site to attempt to account for mercury that might be added to the river via unmonitored locations such as the Savannah River swamp. It should be recognized that compartments within the watershed and water body can store significant amounts of mercury that can continue to cycle through the system even if there is not an ongoing point-source of mercury. The most significant cache of mercury is likely to be the river sediments and adjacent swamps. This simple mass balance does not fully capture this potential source of mercury.

For the SRS mercury mass balance, inputs included mercury discharged from SRS facilities to the environment through the NPDES outfalls, mercury transported to the site in the Savannah River upstream of the site boundary, mercury entering the SRS via streams originating outside of the site boundaries, and atmospheric deposition (Figure 19). Outputs included mercury transported down the Savannah River at the downstream site boundary and revolatilization (Figure 19). Accumulation locations include upland soils, the water column, sediments and biota. This preliminary mass balance calculates initial estimates mass fluxes into the site, and the mass flux leaving the site via the Savannah River. Measurement or estimate of the mass flux of mercury being re-volatilized was beyond the scope of this study. The distribution of mercury between various accumulation pathways was also beyond the scope of this study. These estimates are derived from different data sources, with differing degrees of uncertainty, and with differing degrees of robustness. This should be considered a preliminary view of mercury movement at the SRS.

The flux of total mercury and methylmercury (in $\mathrm{kg} / \mathrm{yr}$ ) flowing through the streams and river was calculated by multiplying mean mercury concentrations and flows. Flows for several SRS streams were determined from USGS flow data at or near the sampling locations. Data from the time period of this study, generally June 1999 through September 2002, were used rather than long term flow averages because the Southeast was in the midst of a multiyear drought during this study and flows were much lower than usual. USGS data were not available at the stream mouths, so EPA estimates of stream mouth flow were used for those calculations. Savannah River flows at the sampling sites were based on USGS data from the Jackson, South Carolina station. Three months of data were missing for that station in 2000. This gap was filled by multiplying flows at the next station downriver (Burton's Ferry Bridge Station) by the historical ratio of flows between the stations. Stream mouth flows were added or subtracted from the average Jackson flow to determine river flows above and below each tributary along the border of the SRS. Flows for the various stations are shown in Table 15.

The results of the flux calculations for total mercury are shown in Table 16. Total mercury flux in the Savannah River entering the mass balance boundary upriver of the SRS was $12.0 \mathrm{~kg} / \mathrm{yr}$, while the flux leaving the boundary was $16.9 \mathrm{~kg} / \mathrm{yr}$, an increase of $4.9 \mathrm{~kg} / \mathrm{yr}$ or $42 \%$. Mercury transported to the river from site streams only accounted for $1.1 \mathrm{~kg} / \mathrm{yr}$ being added to the river, but that value may be low because data was not collected during storm events; mercury levels would be expected to be higher during storm events because as the runoff flows over the ground, it accumulates pollutants that were deposited since the last storm event. Water flowing through the Savannah River swamp during higher storm-related flows could significantly increase mercury flux to the river.

Methylmercury flux was also calculated, though it was not used in the mass balance. Results are shown in Table 17. Methylmercury flux entering the mass balance boundary upstream of the SRS was $0.391 \mathrm{~kg} / \mathrm{yr}$, while the flux leaving the boundary was about $0.463 \mathrm{~kg} / \mathrm{yr}$, an increase of about $0.07 \mathrm{~kg} / \mathrm{yr}$ or $19 \%$. The sum of methylmercury transported to the river from site streams was $0.08 \mathrm{~kg} / \mathrm{yr}$. Again, storm flow effects on mercury concentrations were not factored into these numbers.

The only major onsite stream originating outside of the SRS boundary is Upper Three Runs, whose headwaters arise near Aiken. Mercury flux entering the site boundary through Upper Three Runs was estimated using USGS flow measured at New Ellenton (Table 15) and mercury measurements collected where Highway 278 crosses Upper Three Runs. This sampling station was used for only two sampling events, so data was limited. Using the average of the two samples (1.39 ng/l), an incoming flux of $0.09 \mathrm{~kg} / \mathrm{yr}$ was estimated (Table 16). 


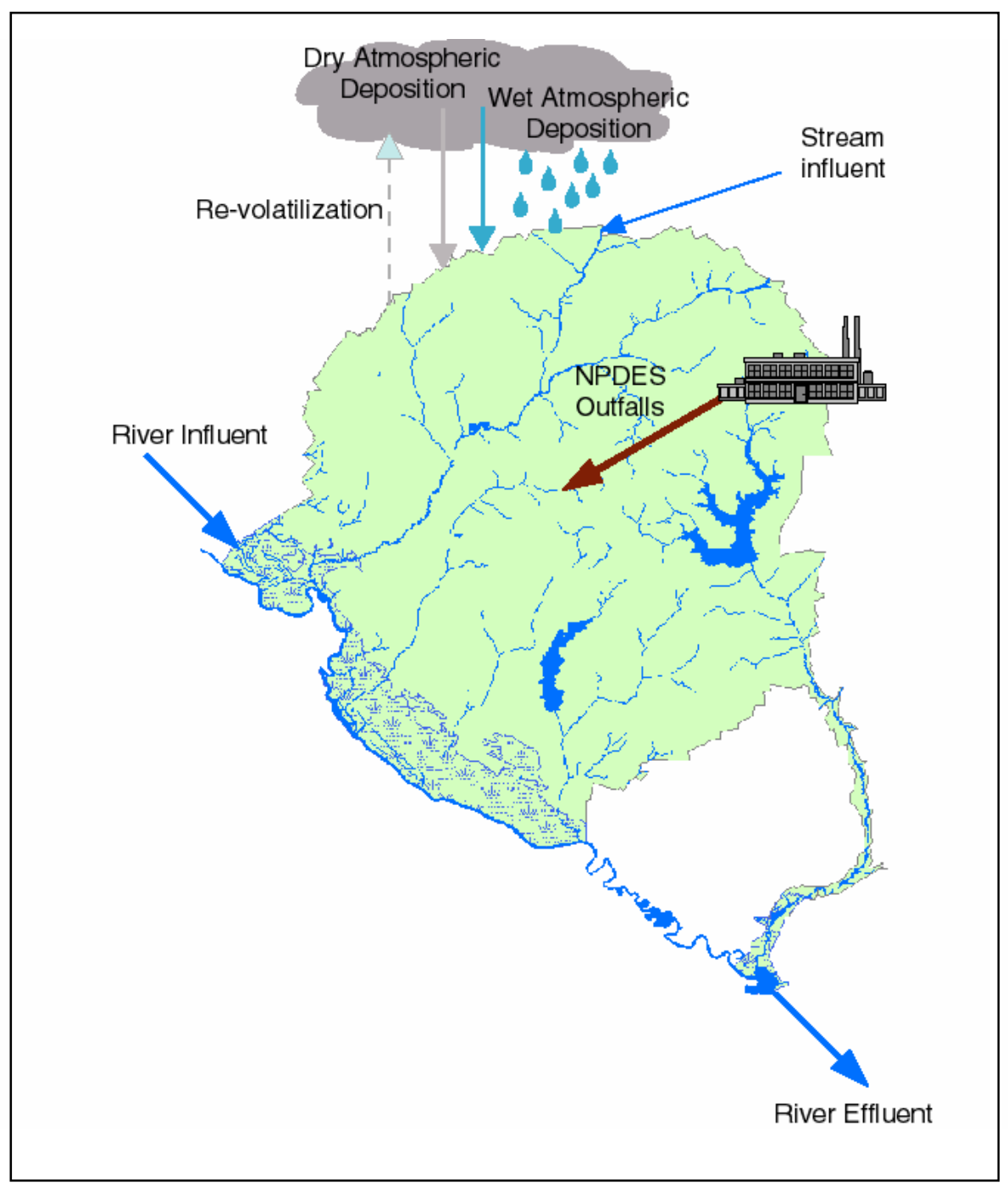

Figure 19. Mercury mass balance inputs and outputs. 
Table 15. SRS stream and Savannah River flows used in mercury mass balance calculations

\begin{tabular}{|c|c|c|}
\hline Location & Flow $\left(\mathrm{m}^{3} / \mathrm{s}\right)$ & Flow Data Source \\
\hline \multicolumn{3}{|l|}{ Stream Locations } \\
\hline Tims Branch at Steeds pond & 0.08 & $\begin{array}{l}\text { USGS average flow (USGS 02197306) for October } 1993 \text { - } \\
\text { September } 1996\end{array}$ \\
\hline Upper Three Runs at Highway 278 & 2.2 & $\begin{array}{l}\text { USGS average flow near New Ellenton (USGS 02197300) } \\
\text { for June } 1999 \text { - September } 2002\end{array}$ \\
\hline $\begin{array}{l}\text { Upper Three Runs at Tyler Bridge } \\
\text { Road }\end{array}$ & 4.3 & $\begin{array}{l}\text { USGS average flow above Road C (USGS 02197310) for } \\
\text { June } 1999 \text { - September } 2002\end{array}$ \\
\hline Upper Three Runs at Highway 125 & 4.5 & $\begin{array}{l}\text { USGS average flow above Road A (USGS 02197315) for } \\
\text { June } 1999 \text { - September } 2002\end{array}$ \\
\hline Beaver Dam Creek at 400D & 2.1 & $\begin{array}{l}\text { USGS average flow (USGS 02197326) for June } 1999 \text { - } \\
\text { September } 2002\end{array}$ \\
\hline Fourmile Branch at Road C & 0.2 & $\begin{array}{l}\text { USGS average flow (USGS 02197340, Site \#6) for June } \\
1999 \text { - September } 2002\end{array}$ \\
\hline Fourmile Branch at swamp inlet & 0.4 & $\begin{array}{l}\text { USGS average flow at Rd. A12.2 (USGS 02197344) for June } \\
1999 \text { - September } 2002\end{array}$ \\
\hline Pen Branch at Road 13.2 & 0.3 & $\begin{array}{l}\text { USGS average flow at Road A-13 (USGS 02197348) for } \\
\text { June } 1999 \text { - September } 2002\end{array}$ \\
\hline Steel Creek at Highway 125 & 0.6 & $\begin{array}{l}\text { USGS average flow at Road A (USGS 21973565) for June } \\
1999 \text { - September } 2002\end{array}$ \\
\hline $\begin{array}{l}\text { Lower Three Runs at Patterson Mill } \\
\text { Road }\end{array}$ & 1.0 & $\begin{array}{l}\text { USGS average flow near Snelling (USGS 02197400) for } \\
\text { June } 1999 \text { - September } 2002\end{array}$ \\
\hline
\end{tabular}

\section{Stream Mouths}

Upper Three Runs at mouth

3.8 EPA estimate

Beaver Dam Creek at mouth

1.1 EPA estimate

Four Mile Creek at mouth

$0.9 \quad$ EPA estimate

Steel Creek at mouth

$3.3 \quad$ EPA estimate

Lower Three Runs at mouth

3.0 EPA estimate

\section{Savannah River}

Savannah River above Upper Three

Runs

USGS flow at Jackson (USGS 02197320) minus EPA estimated UTR flow.

Savannah River below Upper Three

USGS flow at Jackson (USGS 02197320)

Runs

Savannah River below Beaver Dam

Creek

USGS flow at Jackson (USGS 02197320) plus EPA

Savannah River below Fourmile estimated BDC flow.

Branch

157 USGS flow at Jackson (USGS 02197320) plus EPA estimated BDC and FMB flows.

Savannah River below Steel Creek

$160 \quad$ USGS flow at Jackson (USGS 02197320) plus EPA estimated BDC, FMB and SC flows.

Savannah River below Lower Three 163 USGS flow at Jackson (USGS 02197320) plus EPA estimated BDC, FMB, SC and LTR flows.

Sources: USGS data came from USGS 2005

EPA data came from a spreadsheet (USEPA 2000a) accompanying the TMDL 
Table 16. Total mercury flux in site streams and Savannah River using unfiltered data from June 1999 through September 2002.

\begin{tabular}{|c|c|c|c|c|}
\hline \multirow[b]{2}{*}{ Location } & \multirow{2}{*}{$\begin{array}{c}\text { Mean Total Hg } \\
\text { ng/L }\end{array}$} & \multirow{2}{*}{$\begin{array}{l}\text { Flow } \\
\mathbf{m}^{3} / \mathbf{s}\end{array}$} & \multicolumn{2}{|c|}{ Total Hg Flux } \\
\hline & & & g/day & $\mathbf{k g} / \mathbf{y r}$ \\
\hline \multicolumn{5}{|l|}{ Stream Locations } \\
\hline Tims Branch at Steeds Pond & 4.56 & 0.08 & 0.03 & 0.01 \\
\hline Upper Three Runs at Highway 278 & 1.39 & 2.2 & 0.26 & 0.09 \\
\hline Upper Three Runs at Tyler Bridge Road & 3.5 & 4.3 & 1.30 & 0.48 \\
\hline Upper Three Runs at Highway 125 & 3.65 & 4.5 & 1.42 & 0.52 \\
\hline Beaver Dam Creek at 400D & 3.24 & 2.1 & 0.59 & 0.22 \\
\hline Fourmile Branch at Road C & 3.87 & 0.2 & 0.05 & 0.02 \\
\hline Fourmile Branch at swamp inlet & 3.95 & 0.4 & 0.14 & 0.05 \\
\hline Pen Branch at Road 13.2 & 3.29 & 0.3 & 0.09 & 0.03 \\
\hline Steel Creek at Highway 125 & 2.88 & 0.6 & 0.14 & 0.05 \\
\hline Lower Three Runs at Patterson Mill Rd. & 4.29 & 1.0 & 0.38 & 0.14 \\
\hline \multicolumn{5}{|l|}{ Stream Mouths } \\
\hline Upper Three Runs at mouth & 2.76 & 3.8 & 0.90 & 0.33 \\
\hline Beaver Dam Creek at mouth & 4.33 & 1.1 & 0.41 & 0.15 \\
\hline Fourmile Branch at mouth & 3.74 & 0.9 & 0.29 & 0.11 \\
\hline Steel Creek at mouth & $2.91^{\mathrm{a}}$ & 3.3 & 0.84 & 0.31 \\
\hline Lower Three Runs at mouth & 2.3 & 3.0 & 0.59 & 0.22 \\
\hline \multicolumn{5}{|l|}{ Savannah River } \\
\hline Savannah River above Upper Three Runs & 2.51 & 151 & 33 & 12.0 \\
\hline Savannah River below Upper Three Runs & 3.14 & 155 & 42 & 15.3 \\
\hline Savannah River below Beaver Dam Creek & 2.27 & 156 & 31 & 11.2 \\
\hline Savannah River below Fourmile Branch & 2.55 & 157 & 35 & 12.6 \\
\hline Savannah River below Steel Creek & 2.87 & 160 & 40 & 14.5 \\
\hline Savannah River below Lower Three Runs & 3.29 & 163 & 46 & 16.9 \\
\hline
\end{tabular}

a Data from April 17, 2001 was not used here because it did not represent a normal flow condition - water was being released from the bottom of L Lake. 
Table 17. Methylmercury flux in site streams and Savannah River using unfiltered data from June 1999 through September 2002.

\begin{tabular}{lcccc}
\hline & Mean $\mathbf{M e H g}$ & Flow & \multicolumn{2}{c}{ MeHg Flux } \\
\cline { 5 - 5 } Location & $\mathbf{n g} / \mathbf{L}$ & & & $\mathbf{~} \mathbf{s} / \mathbf{s} / \mathbf{y r}$ \\
\hline Stream Locations & & & & \\
Tims Branch at Steeds Pond & 0.213 & 0.08 & 0.002 & 0.0006 \\
Upper Three Runs at Tyler Bridge Road & 0.123 & 4.3 & 0.046 & 0.017 \\
Upper Three Runs at Highway 125 & 0.130 & 4.5 & 0.051 & 0.018 \\
Beaver Dam Creek at 400D & 0.357 & 0.2 & 0.005 & 0.002 \\
Fourmile Branch at Road C & 0.400 & 0.4 & 0.014 & 0.005 \\
Fourmile Branch at swamp inlet & 0.185 & 0.3 & 0.005 & 0.002 \\
Pen Branch at Road 13.2 & 0.087 & 2.1 & 0.016 & 0.006 \\
Steel Creek at Highway 125 & 0.289 & 0.6 & 0.014 & 0.005 \\
Lower Three Runs at Patterson Mill Rd. & 0.272 & 1.0 & 0.024 & 0.009 \\
\hline Stream Mouths & & & & \\
Upper Three Runs at river & 0.176 & 3.8 & 0.057 & 0.021 \\
Beaver Dam Creek at river & 0.115 & 1.1 & 0.011 & 0.004 \\
Fourmile Branch at river & 0.180 & 0.9 & 0.014 & 0.005 \\
Steel Creek at river & 0.220 & 3.3 & 0.064 & 0.023 \\
Lower Three Runs at river & 0.272 & 3.0 & 0.070 & 0.026 \\
\hline Savannah River & & & & \\
Savannah River above Upper Three Runs & 0.082 & 151 & 1.07 & 0.391 \\
Savannah River below Upper Three Runs & 0.090 & 155 & 1.20 & 0.440 \\
Savannah River below Beaver Dam Creek & 0.077 & 156 & 1.04 & 0.379 \\
Savannah River below Fourmile Branch & 0.102 & 157 & 1.38 & 0.505 \\
Savannah River below Steel Creek & 0.089 & 160 & 1.23 & 0.450 \\
Savannah River below Lower Three Runs & 0.090 & 163 & 1.27 & 0.463 \\
\hline
\end{tabular}

The contribution of SRS operations to the mercury mass balance was calculated from NPDES outfall measurements. Using mean outfall flows obtained from Discharge Monitoring Reports from January 2000 to December 2002 (WSRC 2000, WSRC 2001, WSRC 2002, WSRC 2003) and mean mercury concentrations measured at each outfall, the mass of mercury released to site streams from SRS facilities was calculated (Table 18). Outfalls M-05 and A-1A, which receive treated groundwater air stripper effluents, had the highest loadings at $93 \mathrm{~g} / \mathrm{yr}$ and $88 \mathrm{~g} / \mathrm{yr}$, respectively. Outfall X-08 also received relatively high mercury loading due to groundwater air stripper effluent. Much of the mercury released to outfalls does not actually reach the receiving streams, as evidenced by comparing results at outfalls M-05 and A-11. Outfall A-11 receives flow from Outfall M-05 and other SRS facilities. However, the mass flux at A-11 (28 g/yr) was considerably smaller than the flux from outfall M-05 upstream (93 g/yr), indicating that much of the mercury was bound to sediments or otherwise immobilized before it reached the downstream outfall. Similarly, mercury flux at outfall A-1A was $88 \mathrm{~g} / \mathrm{yr}$, while the downstream outfall A-01 received only $51 \mathrm{~g} / \mathrm{yr}$. This reduction of mercury in the water column over such a small distance would indicate that much of the mercury discharged to site outfalls would never reach the more distant river. Using only the downstream-most outfalls in those locations where outfalls lead into other outfalls, the total mass of mercury released to site streams from NPDES outfalls was calculated to be approximately $0.2 \mathrm{~kg} / \mathrm{yr}$ during the study (Table 18). This release of mercury through the outfalls is less than $2 \%$ of the mercury flux in the Savannah River, though only a small portion of it is expected to reach the river. 
Table 18. Mercury loading to surface water from SRS NPDES Outfalls, based on samples collected from August 1999 through September 2002.

\begin{tabular}{|c|c|c|c|c|c|}
\hline \multicolumn{2}{|c|}{ Outfall } & $\begin{array}{c}\text { Final Mean Conc. } \\
\text { (ng/L) }\end{array}$ & Flow $\left(\mathrm{m}^{3} / \mathbf{d}\right)^{\mathbf{b}}$ & $\begin{array}{c}\text { Individual loading } \\
\text { (mg/day) }\end{array}$ & $\begin{array}{c}\text { Individual loading } \\
\text { (g/yr) }\end{array}$ \\
\hline \multirow{2}{*}{\multicolumn{2}{|c|}{$\underline{A}^{A-01} A-1 A^{a}$}} & 46.6 & 3022 & 141 & 51 \\
\hline & & 139.4 & 1732 & $(241)$ & (88) \\
\hline \multirow{2}{*}{ A-11 } & \multirow{3}{*}{$M-05^{\mathrm{a}}$} & 27.4 & 2763 & 76 & 28 \\
\hline & & 105.1 & 2424 & (255) & (93) \\
\hline D-1A & & 54.1 & 14 & 0.74 & 0.27 \\
\hline \multicolumn{2}{|l|}{ F-01 } & 1.3 & 127 & 0.17 & 0.061 \\
\hline \multicolumn{2}{|l|}{ F-02 } & 4.7 & 350 & 1.6 & 0.60 \\
\hline \multicolumn{2}{|l|}{ F-05 } & 36.3 & 136 & 4.9 & 1.8 \\
\hline \multicolumn{2}{|l|}{ F-08 } & 3.2 & 5234 & 17 & 6.1 \\
\hline \multicolumn{2}{|l|}{ G-10 } & 21.7 & 889 & 19 & 7.1 \\
\hline \multicolumn{2}{|l|}{$\mathrm{H}-02$} & 7.1 & 404 & 2.9 & 1.0 \\
\hline \multicolumn{2}{|l|}{$\mathrm{H}-04$} & 4.1 & 30 & 0.12 & 0.045 \\
\hline \multicolumn{2}{|l|}{$\mathrm{H}-07$} & 7.4 & 42 & 0.31 & 0.11 \\
\hline \multicolumn{2}{|l|}{$\mathrm{H}-08$} & 3.5 & 1912 & 6.6 & 2.4 \\
\hline \multicolumn{2}{|l|}{$\mathrm{H}-12$} & 4.4 & 1444 & 6.4 & 2.3 \\
\hline \multicolumn{2}{|l|}{$\mathrm{H}-16$} & 6.2 & 699 & 4.3 & 1.6 \\
\hline \multicolumn{2}{|l|}{ K-04 } & 16.7 & Not available & Not available & Not available \\
\hline \multicolumn{2}{|l|}{$\mathrm{K}-06$} & 6.0 & 125 & 0.75 & 0.28 \\
\hline \multirow{2}{*}{ K-18 } & \multirow{3}{*}{$\mathrm{K}-12^{\mathrm{a}}$} & 1.3 & 1038 & 1.3 & 0.49 \\
\hline & & 7.5 & 8 & $(0.057)$ & $(0.021)$ \\
\hline \multirow{2}{*}{$\stackrel{\mathrm{L}-07}{L^{2}}$} & & 2.7 & 30663 & 84 & 31 \\
\hline & \multirow[t]{2}{*}{$L-7 A^{a}$} & 42.8 & 5 & $(0.22)$ & $(0.081)$ \\
\hline L-08 & & 1.8 & 155 & 0.28 & 0.10 \\
\hline \multicolumn{2}{|l|}{ PP-1 } & 14.4 & 3 & 0.038 & 0.014 \\
\hline \multicolumn{2}{|l|}{ S-04 } & 4.6 & 268 & 1.2 & 0.45 \\
\hline \multicolumn{2}{|l|}{$\mathrm{X}-04$} & 101.5 & 9 & 0.91 & 0.33 \\
\hline \multirow{2}{*}{$\mathrm{X}-08$} & \multirow{3}{*}{$\begin{array}{l}X-8 A^{a} \\
X-8 B^{a}\end{array}$} & 194.5 & 970 & 189 & 69 \\
\hline & & 33.7 & 5 & $(0.16)$ & $(0.060)$ \\
\hline L & & 84.0 & 78 & (6.5) & $(2.4)$ \\
\hline$\square$ & $X-8 C^{a}$ & 443.2 & 341 & (151) & (55) \\
\hline ТОТА & & & & $558^{c}$ & 204 \\
\hline
\end{tabular}

a This outfall feeds into another outfall, as indicated. Loadings for these outfalls are shown in parentheses, but are not included in the totals because they are captured by the downstream outfall calculations.

b Average flows from 2000 - 2002 discharge monitoring reports.

c The total does not include those outfalls which feed into another outfall so that the loadings are not counted twice.

Results from the atmospheric deposition study were used along with rainfall measurements to determine total direct wet deposition of mercury on SRS. Deposition outside of the boundaries of the SRS was not included, even though it may fall on a watershed drained by SRS streams. Daily rainfall measurements for all the meteorological stations at SRS for the period 2000 - 2002 were used to calculate the average annual rainfall for the SRS during the period of the study, 40.6 inches $(103 \mathrm{~cm})$. The average annual rainfall was multiplied by the area of the SRS (310 square miles or 800 square $\mathrm{km})$ and the volume-weighted average rainfall concentration $(12.56 \mathrm{ng} / \mathrm{l})$ from the SC03 monitoring site to determine the annual mass wet deposition of mercury on the SRS, approximately $10 \mathrm{~kg} / \mathrm{yr}$. Roughly the same result was achieved by multiplying the average deposition rate $(238.05 \mathrm{ng} / \mathrm{m} 2$ per week or 12.38 $\mu \mathrm{g} / \mathrm{m}^{2}$ per year) by SRS surface area. Using the average rainfall and deposition data from the four Georgia and 
South Carolina monitoring sites (11.00 ng/l and $224.7 \mathrm{ng} / \mathrm{m}^{2} /$ week), rather than just the SC03 site resulted in a calculated total annual wet deposition of mercury on the SRS of approximately $9 \mathrm{~kg} / \mathrm{yr}$.

During development of the TMDL, the EPA determined that the average dry deposition rate was about 2/3 of the wet deposition rate (USEPA 2001b). Using the same ratio, dry deposition of mercury on the SRS was calculated from the measured wet deposition to be approximately $7 \mathrm{~kg} / \mathrm{yr}$. Total atmospheric deposition (wet plus dry) was then calculated to be approximately $17 \mathrm{~kg} / \mathrm{yr}$.

The various flux calculations are summarized in Figure 20. Influent mercury, comprised of influent from the Savannah River and Upper Three Runs, mercury added by SRS operations via the NPDES outfalls, and wet and dry atmospheric deposition, totaled approximately $30 \mathrm{~kg} / \mathrm{yr}$. Effluent mercury included $16.9 \mathrm{mg} / \mathrm{yr}$ via the river and an undetermined quantity re-volatilizing to the atmosphere. Assuming a balance, the sum of the mercury storage and re-volatilization within the boundary drawn for this study was approximately $13 \mathrm{~kg} / \mathrm{yr}$. Atmospheric deposition alone (17 kg/yr) far exceeded mercury leaving the site via the SRS streams $(1.1 \mathrm{~kg} / \mathrm{yr})$, indicating that approximately $95 \%$ of the deposited mercury was being retained in the soil, sediments, water bodies or vegetation, or was being reemitted to the atmosphere. These findings support the conclusions in other studies (Lindberg et al. 2002, Ericksen and Gustin 2004, Ericksen et al. 2002, Hintelmann et al 2002, Landis and Keeler 2002), which found that a significant fraction of atmospherically deposited mercury volatilizes or is bound to soil and vegetation. In addition, mercury released through the SRS outfalls was equivalent to approximately $1 \%$ of the total atmospheric deposition on the SRS, which aligns with the theory that atmospheric deposition is the major source of mercury to the SRS environment and supported EPA's determination that point source discharges contribute only $1 \%$ of the mercury loading to the watershed. 


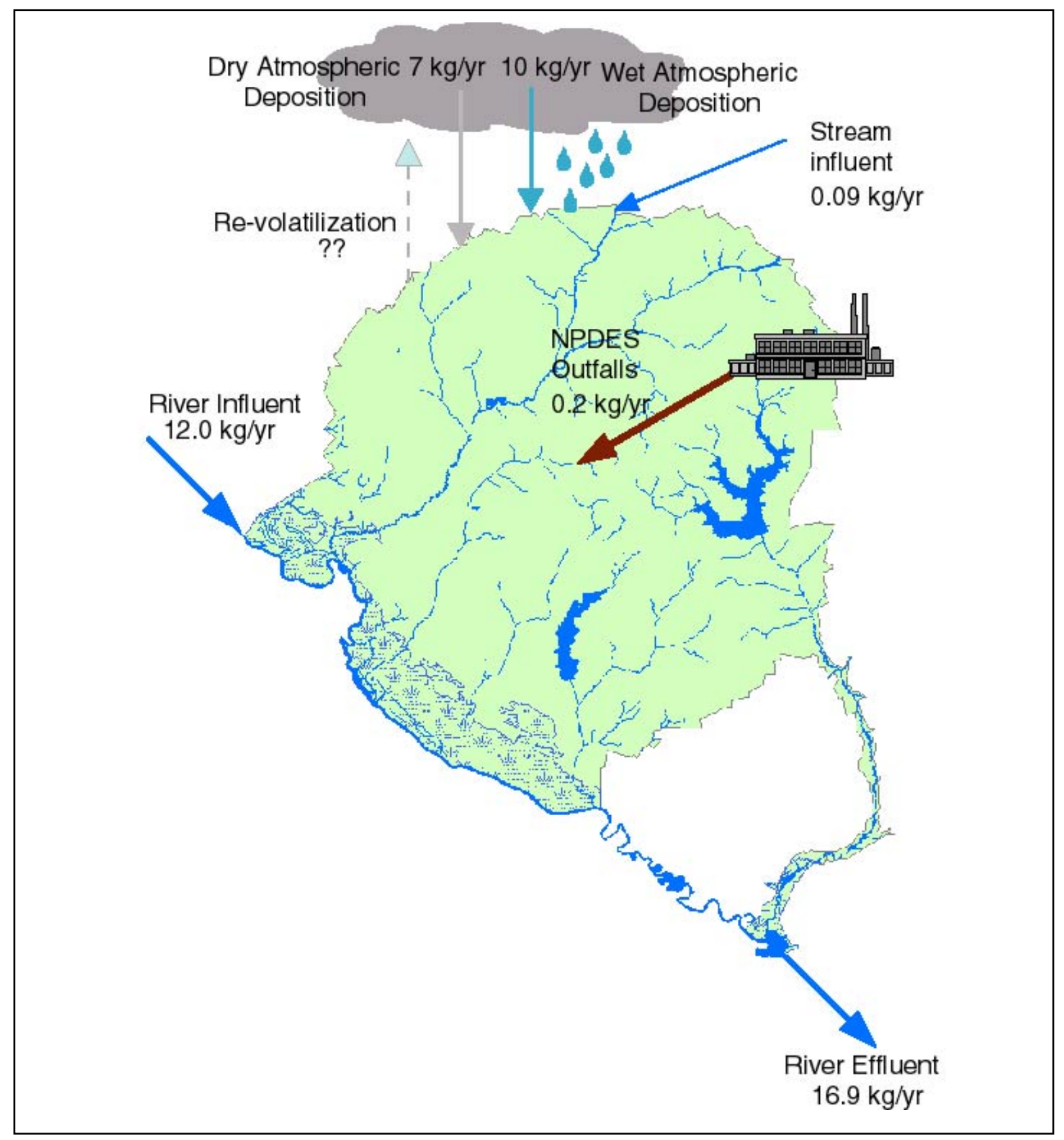

Figure 20. Mercury flux into and out of the SRS Boundary area based on data from June 1999 through September 2002. 


\section{References}

Albenesius, E.L. 1972. Mercury in the Par Pond System. E.I. du Pont de Nemours \& Co., Savannah River Laboratory, Aiken, SC.

Balogh, S., M. Meyer, K. Johnson. 1998. Diffuse and Point Source Mercury Inputs to the Mississippi, Minnesota, and St. Croix Rivers. Sci. Tot. Env. 213: 109-113.

Benoit, J.M., C.C. Gilmour, R.P. Mason, A. Heyes. 1999. Sulfide Controls on Mercury Speciation and Bioavailability in Sediment Pore Waters. Environ. Sci. Technol. 33: 951-957.

Berra, T.M., G.E. Gunning. 1972. Seasonal Movement and Home Range of the Longear Sunfish, Lepomis megalotis (Rafinesque) in Louisiana. Am. Midl. Nat. 88: 368-374.

Blank, S., C. Seiter, P. Bruce. 1999. Resampling Stats Excel. Resampling Stats, Inc., Arlington, Va.

Bloom, N.S. 1989. Determination of Picogram Levels of Methylmercury by Aqueous Phase Ethylation, Followed by Cryogenic Gas Chromatography with Cold Vapor Atomic Fluorescence. Can. J. Fish Aquat. Sci. 46: 11311140 .

Bloom, N.S. 1992. On the Chemical Form of Mercury in Edible Fish and Marine Invertebrate Tissue. Can. J. Fish Aquat. Sci. 49: 1010-1017.

Bloom, N.S. 1993. Ultra-Clean Sampling, Storage, and Analytical Strategies for Accurate Determination of Trace Metals in Natural Waters. Proceedings of the 16th Annual EPA Conference on Analysis of Pollutants in the Environment. EPA 821-R-94-001. Washington, DC.

Bloom, N.S. 1995. Mercury as a Case Study of Ultra-Clean Sample Handling and Storage in Aquatic Trace Metal Research. Environ. Lab 3-4: 20-25.

Bloom, N.S., E.A. Crecelius. 1983. Determination of Mercury in Sea Water at Subnanogram per Liter Levels. Mar. Chem. 14: 49.

Bloom, N.S., W.F. Fitzgerald. 1988. Determination of Volatile Mercury Species at the Picogram Level by LowTemperature Gas Chromatography with Cold-Vapor Atomic Fluorescence Detection. Anal. Chim. Acta 208: 151 .

Bowles, K.C., S.C. Apte, W.A. Maher, M. Kawei, R. Smith. 2001. Bioaccumulation and Biomagnification of Mercury in Lake Murray, Papua New Guinea. Can. J. Fish Aquat. Sci. 58: 888-897.

Burrows, W.C., P.A. Krenkel. 1973. Studies on Uptake and Loss of Methylmercury-203 by Bluegills (Lepomis macrochirus). Environ. Sci. Technol. 7: 1127-1130.

Cabana, G., A. Tremblay, J. Kalff, J.B. Rasmussen. 1994. Pelagic Food Chain Structure in Ontario Lakes: a Determinant of Mercury Levels in Lake Trout (Salvelinus namaycush). Can. J. Fish Aquat. Sci. 51: 381389.

Canavan, C.M., C.A. Caldwell, N.S. Bloom. 2000. Discharge of Methylmercury-Enriched Hypolimnetic Water from a Stratified Reservoir. Sci. Tot. Environ. 260: 159-170.

Chase, M.E., S.H. Jones, P. Hennigar, J. Sowles, G.C.H. Harding, K. Freeman, P.G. Wells, C. Krahforst, K. Coombs, R. Crawford, J. Pederson, D. Taylor. 2001. Gulfwatch: Monitoring Spatial and Temporal Patterns of Trace Metal and Organic Contaminants in the Gulf of Maine (1991-1997) with the Blue Mussel, Mytilus edulis L. Marine Pollution Bulletin 42: 491-505.

Clarkson, T.W. 1990. Human Health Risks from Methylmercury in Fish. Environ. Toxicol. Chem. 9: $957-961$. 
Cope, W.G., J.G. Weiner, R.G. Rada. 1990. Mercury Accumulation in Yellow Perch in Wisconsin Seepage Lakes: Relation to Lake Characteristics. Environ. Toxicol. Chem. 9: 931-940.

Cope, W.G., M.R. Bartsch, R.G. Rada, S.J. Balogh, J.E. Rupprecht, R.D. Young, D.K. Johnson. 1999. Bioassessment of Mercury, Cadmium, Polychlorinated Biphenyls, and Pesticides in the Upper Mississippi River with Zebra Mussels (Dreissena polymorpha). Environ. Sci. Technol. 33: 4385-4390.

Dames, H.R., T.G. Coon. 1989. Movements of Channel and Flathead Catfish between the Missouri River and a Tributary, Perche Creek. Tran. Am. Fish Soc. 118(6): 670-679.

Downs, S.G., C.L. Macleod, J.N. Lester. 1998. Mercury in Precipitation and its Relation to Bioaccumulation in Fish: a Literature Review. Water, Air, \& Soil Pollu. 108: 149-187.

Eisler, R. 1987. Mercury Hazards to Fish, Wildlife, and Invertebrates: a Synoptic Review. U.S. Fish Wildl. Serv. Biol. Rep. 85(1.10).

Ericksen, J.A., M.S. Gustin. 2004. Foliar Exchange of Mercury as a Function of Soil and Air Mercury Concentrations. Sci. Tot. Env. 324: 271-279

Ericksen, J.A., M.S. Gustin, D.E. Schorran, D.W. Johnson, S.E. Lindberg, J.S. Coleman. 2002. Accumulation of Atmospheric Mercury in Forest Foliage. Atmospheric Environment 37: 1613-1622.

Evans, M., N. Hastings, B. Peacock. 1993. Statistical Distributions. 3rd. Ed. John Wiley \& Sons, Inc., New York.

Fitzgerald, W.F., R.P. Mason, G.M. Vandal. 1991. Atmospheric Cycling and Air-Water Exchange of Mercury over Mid-Continental Lacustrine Regions. Water, Air, Soil \& Pollu. 56: 745-767.

Flotemersch, J.E., D.C. Jackson, J.R. Jackson. 1997. Channel Catfish Movements in Relation to River Channel Floodplain Connections. Proc. Annual Conf. Southeast Assoc. Fish and Wildlife Agencies 51: 106-112.

Foster, E.P., D.L. Drake, G. DiDomenico. 2000. Seasonal Changes and Tissue Distribution of Mercury in Largemouth Bass (Micropterus salmoides) from Dorena Reservoir, Oregon. Arch. Environ. Contam. Toxicol. 38: 78-82.

Francis, D.R., D.J. Jude, J.A. Barres. 1998. Mercury Distribution in the Biota of a Great Lakes Estuary: Old Woman Creek, Ohio. J. Great Lakes Res. 24: 595-607.

Gatz, A.J. Jr., S.M. Adams. 1994. Patterns of Movement of Centrarchids in two Warmwater Streams in Eastern Tennessee. Ecol. Freshwater Fish 3: 35-48.

Gilmour, C.C., E.A. Henry. 1991. Mercury Methylation in Aquatic Systems Affected by Acid Deposition. Environ. Pollut. 71: 131-169.

Gilmour, C.C., E.A. Henry, R. Mitchell. 1992. Sulfate Stimulation of Mercury Methylation in Freshwater Sediments. Environ. Sci. Technol. 26(11): 2281-2287.

Gilmour, C.C., G.S. Riedel, M.C. Ederington, J.T. Bell, J.M. Benoit, G.A. Gill, M.C. Stordal. 1998. Methylmercury Concentrations and Production Rates across a Trophic Gradient in the Northern Everglades. Biogeochemistry. 40:327-345.

Gray, J.E., P.M. Theodorakos, E.A. Bailey, R.R. Turner. 2000. Distribution, Speciation, and Transport of Mercury in Stream-Sediment, Stream-Water, and Fish Collected near Abandoned Mercury Mines in Southwestern Alaska, USA. Sci. Tot. Env. 260:21-33. 
Halverson, N.V., J.K. King, D.G. Jackson, M.H. Paller, J.W. Koch. 2000a. Aquatic Mercury Assessment Interim Data Report: February 2001. WSRC-TR-2000-00454. Savannah River Technology Center, Westinghouse Savannah River Company, Aiken, SC.

Halverson, N.V., J.K. King, D.G. Jackson, M.H. Paller. 2000b. Sampling Plan for FY 2001 Aquatic Mercury Assessment at the Savannah River Site. WSRC-TR-2000-00497. Savannah River Technology Center, Westinghouse Savannah River Company, Aiken, SC.

Halverson, N.V., J.A. Bowers, D.G. Jackson, M.H. Paller, F.D. Martin. 2002. Aquatic Mercury Assessment Interim Data Report: October 2000 - September 2001. WSRC-TR-2002-00106. Savannah River Technology Center, Westinghouse Savannah River Company, Aiken, SC.

Hildebrand, S.G., A.W. Andren, J.W. Huckabee. 1976. Distribution and Bioaccumulation of Mercury in Biotic and Abiotic Compartments of a Contaminated River-Reservoir System. In Andrew R.W., P.V. Hodson, and D.E. Konasewich (eds). Toxicity to Biota of Metal Forms in Natural Waters. Standing Committee on the Scientific Basis for Water Quality Criteria of the International Joint Commission's Research Advisory Board, pp 211-232.

Hintelmann, H., R. Harris, A. Heyes, J.P. Hurley, C.A. Kelly, D.P. Krabbenhoft, S. Lindberg, J.W.M. Rudd, K.J. Scott, V.L. St. Louis. 2002. Reactivity and Mobility of New and Old Mercury Deposition in a Boreal Forest Ecosystem during the First Year of the METAALICUS Study. Environ. Sci. Technol., 36 (23).

Horvat, M., N.S. Bloom, L. Liang. 1993. Comparison of Distillation with Other Current Isolation Methods for the Determination of Methylmercury Compounds in Low Level Environmental Samples. Part I. Sediments. Anal. Chim. Acta 281: 135-152.

Hurley, J.P., J.M. Benoit, C.L. Babiarz, M.M. Shafer, A.W. Andren, J.R. Sullivan, R. Hammond, D.A. Webb 1995. Influences of Watershed Characteristics on Mercury Levels in Wisconsin Rivers. Environ. Sci. Technol. 29: 1867-1875.

Hurley, J.P., D.P. Krabbenhoft, L.B. Cleckner, M.L. Olson, G.R. Aiken, P.S. Rawlik, Jr. 1998a. System Controls on the Aqueous Distribution of Mercury in the Northern Florida Everglades. Biogeochemistry 40: 293-310.

Hurley, J.P., S.E. Cowell, M.M. Shafer, P.E. Hughes. 1998b. Tributary Loading of Mercury to Lake Michigan: Importance of Seasonal Events and Phase Partitioning. Sci. Tot. Env. 213: 129-137.

Inza, B., F. Ribeyre, R. Maury-Brachet, A. Boudou. 1997. Tissue Distribution of Inorganic Mercury, Methylmercury and Cadmium in the Asiatic Clam (Corbicula fluminea) in Relation to the Contamination Levels of the Water Column and Sediment. Chemosphere 35: 2817-2836.

Inza, B., F. Ribeyre, A. Boudou. 1998. Dynamics of Cadmium and Mercury Compounds (Inorganic Mercury or Methylmercury): Uptake and Depuration in Corbicula fluminea. Effects of Temperature and pH. Aquatic Toxicology 43: 273-285.

Jones, T.A. 2001. Seasonal and Diel Movement of Largemouth Bass in a South Carolina Stream. Thesis presented to the graduate school of Clemson University, Clemson, SC.

Kvartek, E.J., W.H. Carlton, M. Denham, L. Eldridge, M.C. Newman. 1994. Assessment of Mercury in the Savannah River Site Environment. WSRC-TR-94-0218ET. Westinghouse Savannah River Company, Aiken, SC.

Landis, M.S., G.J. Keeler. 2002. Atmospheric Mercury Deposition to Lake Michigan during the Lake Michigan Mass Balance Study. Environ. Sci. Technol. 36 (21).

Lacerda, L.D., W.F. Fitzgerald. 2001. Biogeochemistry of Mercury in Wetlands. Wetlands Ecology and Management 9: 291-293. 
Liang, L., M. Horvat, N.S. Bloom. 1994. An Improved Speciation Method for Mercury by GC/CVAFS after Aqueous Phase Ethylation and Room Temperature Precollection. Talanta. 41: 371-379.

Lindberg, S.E., W. Dong, T. Tilden Meyers. 2002. Transpiration of Gaseous Elemental Mercury through Vegetation in a Subtropical Wetland in Florida. Atmospheric Environment 36: 5207-5219.

Looney, B.B., D.G. Jackson, M.E. Denham. 1998. Evaluation of Background Mercury Concentrations in the SRS Groundwater System. WSRC-RP-98-01362. Savannah River Technology Center, Westinghouse Savannah River Company, Aiken, SC 29808.

Macalady, J.L., E.E. Mack, D.C. Nelson, K.M. Scow. 2000. Sediment Microbial Community Structure and Mercury Methylation in Mercury-polluted Clear Lake, California. Appl. Environ. Microbiol. 66, Amer. Soc. Microbiol. Washington, D. C.

Mason, R.P., W.F. Fitzgerald, F.M.M. Morel. 1994. The Biogeochemical Cycling of Elemental Mercury; Anthropogenic Influences. The Clair C. Patterson special issue. Geochimica et Cosmochimica Acta 58: 3191-3198.

Mason, R.P., N.M. Lawson, K.A. Sullivan. 1997. The Concentration, Speciation and Sources of Mercury in Chesapeake Bay Precipitation. Atmospheric Environment 31(21): 3541-3550.

Mason, R.P., N.M. Lawson, A.L. Lawerence, J.J. Leaner, J.G. Lee, G.R. Sheu. 1999. Mercury in the Chesapeake Bay. Mar. Chem. 66: 77-96.

Mason, R.P., N.M. Lawson, G.R. Sheu. 2000. Annual and Seasonal Trends in Mercury Deposition in Maryland. Atmospheric Environment 34: 1691-1701.

McKim, J.M., G.F. Olson, G.W. Holcombe, E.P. Hunt. 1976. Long-Term Effects of Methylmercuric Chloride on Three Generations of Brook Trout (Salvelinus fontinalis): Toxicity, Accumulation, Distribution, and Elimination. J. Fish Res. Board Can. 33: 2726-2739.

Munn, M.D., T.M. Short. 1997. Spatial Heterogeneity of Mercury Bioaccumulation by Walleye in Franklin D. Roosevelt Lake and the Upper Columbia River, Washington. Tran. Am. Fish Soc. 126: 477-487.

Mierle, G. 1990. Aqueous Inputs of Mercury to Precambrian Shield Lakes in Ontario. Environmental Toxicology and Chemistry 9: 843-851.

Nater, E.A., D.F. Grigal. 1992. Regional Trends in Mercury Distribution across the Great Lakes States, North Central USA. Nature 358:139-141.

National Atmospheric Deposition Program (NRSP-3)/Mercury Deposition Network (2003). NADP Program Office, Illinois State Water Survey, Champaign, IL 61820.

Nelson, E.A., W.L. Specht, J.A. Bowers, J.B. Gladden. 2002. Constructed Wetlands for Removal of Heavy Metals from NPDES Outfall Effluent. WSRC-MS-2002-00600. Westinghouse Savannah River Company, Savannah River Technology Center, Aiken, SC.

Newman, M.C., A. Messier. 1994. Mercury Bioaccumulation in Mosquitofish (Gambusia holbrooki) Samples on and around the Savannah River Site. SREL-48/UC-66e. Savannah River Ecology Laboratory, Aiken, SC.

Oblath, S.B. 1985. 1984 Monitoring of Mercury in the Groundwater at 643-G and 643-7G. DPST-85-407. E. I. du Pont de Nemours \& Co., Savannah River Laboratory, Aiken, SC. 29808.

Paller, M.H., J.W. Littrell. 2007. Long-term Changes in Mercury Concentrations in Fish from the Middle Savannah River. Sci. Tot. Env. 382: 375-382. 
Paller, M.H., J. O'Hara, D.V. Osteen. 1985. Annual Report on the Savannah River Aquatic Ecology Program. September 1983 - August 1984. Vol. II. Ichthyoplankton. ECS-SR-18. Environmental and Chemical Sciences, Inc., Aiken, SC.

Paller, M.H., B.M. Saul, D.V. Osteen. 1986. Distribution and Abundance of Ichthyoplankton in the Mid-Reaches of the Savannah River and Selected Tributaries. DPST-86-798. Prepared by Environmental and Chemical Sciences, Inc. for E. I. du Pont de Nemours and Company, Savannah River Laboratory, Aiken, SC.

Paller, M.H., C.H. Jagoe, H. Bennett, H.A. Brant, J.A. Bowers. 2004. Influence of Methylmercury from Tributary Streams on Mercury Levels in Savannah River Asiatic Clams. Sci. Tot. Env. 325: 209-219.

Palisade Corporation. 2002. BestFit Version 4.5, Newfield, NY.

Park, J.G., L.R. Curtis. 1997. Mercury Distribution in Sediments and Bioaccumulation by Fish in two Oregon Reservoirs: Point-Source and Nonpoint-Source Impacted Systems. Arch. Environ. Contam. Toxicol. 33: 423-429.

Price, V., J.R. Cook. 1988. Mercury in Shallow Savannah River Plant Soil. DPST-86-314. E. I. du Pont de Nemours \& Co., Savannah River Laboratory, Aiken, SC.

Regnell, O. 1994. The Effect of pH and Dissolved Oxygen Levels on Methylation and Partitioning of Mercury in Freshwater Model Systems. Environmental Pollution 84: 7-13.

Regnell, O., G. Ewald, E. Lord. 1997. Factors Controlling Temporal Variation in Methyl Mercury Levels in Sediment and Water in a Seasonally Stratified Lake. Limnol. Oceanogr. 42: 1784-1795.

SAS. 1995.JMP@ Manual, SAS Institute Inc., Cary, NC., U.S.A.

Schetagne, R., J.F. Doyon, J.J. Fournier. 2000. Export of Mercury Downstream from Reservoirs. Sci. Tot. Env. 260: 135-145.

Searle, S.R., F.M. Speed, G.A. Milliken. 1980. Populations Marginal Means in the Linear Model: an Alternative to Least Squares Means. Am. Stat. 34: 216-221.

Sellers, P., C.A. Kelly, J.W.M. Rudd. 2001. Fluxes of Methylmercury to the Water column of a Drainage Lake: the Relative Importance of Internal and External Sources. Limnol. Oceanogr. 46: 623-631.

Simon, J.L. 1999. Resampling Stats User’s Guide. Resampling Stats, Inc., Arlington, Va.

Smith, L., C. Jagoe, F. Carl. 2007. Chlor Alkali Plant Contributes to Mercury Contamination in the Savannah River. Proceedings of the 2007 Georgia Water Resources Conference. Georgia Water Resources Institute, Atlanta, GA.

Sokal, R.R., F.J. Rohlf. 1981. Biometry, second edition. WH Freeman and Company, San Francisco.

Sokal, R.R., F.J. Rohlf. 1995. Biometry, 3rd edition. WH Freeman, New York.

Southworth, G.R., R.R. Turner, M.J. Peterson, M.A. Bogle. 1995. Form of Mercury in Stream Fish Exposed to High Concentrations of Dissolved Inorganic Mercury. Chemosphere 30: 779-787.

SPSS. 1997. Systat 7.0. SPSS Inc., Chicago.

St. Louis, V.L., J.W.M. Rudd, C.A. Kelly, K.G. Beaty, N.S. Bloom, R.J. Flett. 1994. Importance of Wetlands as Sources of Methylmercury to Boreal Forest Ecosystems. Can. J. Fish Aquat. Sci. 51: 1065-1076. 
Strom, D.G., G.A. Graves. 2001. A Comparison of Mercury in Estuarine Fish between Florida Bay and the Indian River Lagoon, Florida, USA. Estuaries 24: 597-609.

Taylor, L.R. 1961. Aggregation, Variance and the Mean. Nature 189:732-735.

USEPA (United States Environmental Protection Agency). 1991. Methods for Determination of Metals in Environmental Samples, EPA-600/4-91-010. Environmental Systems Laboratory, United States Environmental Protection Agency, Cincinnati, Ohio.

USEPA (United States Environmental Protection Agency). 1994. Clean Water Act 303(D) TMDL Program. EPA 841-K-94-004. Department of Commerce, National Technical Information Service, Springfield, VA.

USEPA (United States Environmental Protection Agency). 1997a. Mercury Study Report to Congress, Volume I: Executive Summary. EPA-452/R-97-003. Office of Air Quality Planning \& Standards and Office of Research and Development, United States Environmental Protection Agency.

USEPA (United States Environmental Protection Agency). 1997b. Mercury Study Report to Congress, Volume II: An Inventory of Anthropogenic Mercury Emissions in the United States. EPA/452/R-97/004. Office of Air Quality Planning \& Standards and Office of Research and Development. United States Environmental Protection Agency.

USEPA (United States Environmental Protection Agency). 1997c. Mercury Study Report to Congress, Volume III: Fate and Transport of Mercury in the Environment. EPA-452/R-97-005. Office of Air Quality Planning \& Standards and Office of Research and Development. United States Environmental Protection Agency.

USEPA (United States Environmental Protection Agency). 2000a. Spreadsheet savflow.xls accompanying the TMDL. United States Environmental Protection Agency, Region 4. Atlanta, GA.

USEPA (United States Environmental Protection Agency). 2000b. Total Maximum Daily Load (TMDL) Development for Total Mercury in the Middle/Lower Savannah River, GA. United States Environmental Protection Agency, Region 4, Atlanta GA.

USEPA. (United States Environmental Protection Agency). 2001a. Guidance for Implementation and Use of EPA Method 1631 for the Determination of Low-Level Mercury (40 CFR part 136). EPA 821-R-01-023. United States Environmental Protection Agency.

USEPA (United States Environmental Protection Agency). 2001b. Total Maximum Daily Load (TMDL) for Total Mercury in Fish Tissue Residue in the Middle \& Lower Savannah River Watershed. United States Environmental Protection Agency, Region 4, Atlanta, GA.

USEPA (United States Environmental Protection Agency). 2001c. Water Quality Criterion for the Protection of Human Health: Methylmercury. EPA-823-R-01-001. Office of Science and Technology, Office of Water, United States Environmental Protection Agency, Washington, DC.

USEPA (United States Environmental Protection Agency). 2002. Notice of withdrawal of TMDL. Letter from United States Environmental Protection Agency, Region 4, Atlanta, GA.

USGS (United States Geological Survey). 2005. Daily Streamflow for the Nation, from website http://nwis. waterdata.usgs.gov/usa/nwis/discharge. United States Geological Survey. Reston, VA.

Watras, C.J., K.A. Morrison, N.S. Bloom. 1995a. Mercury in Remote Rocky Mountain Lakes of Glacier National Park, Montana, in Comparison with Other Temperate North American Regions. Can. J. Fish. Aquat. Sci. 52: $1220-1228$.

Watras, C.J., K.A. Morrison, J.S. Host, N.S. Bloom. 1995b. Concentration of Mercury Species in Relationship to 
Other Site-Specific Factors in the Surface Waters of Northern Wisconsin Lakes. Limnol. Oceanogr. 40: 556-565

Watras, C.J., K.A. Morrison, J.S. Host, N.S. Bloom. 1995c. Chemical Correlates of Hg and Methyl-Hg in Northern Wisconsin Lake Waters Under Ice-Cover. Water, Air, \& Soil Pollu.. 84: 253-267.

WSRC (Westinghouse Savannah River Company). 2000. National Pollutant Discharge Elimination System Discharge Monitoring Reports. Individual reports for January through November 2000 were ESH-ESS2000-00048, ESH-ESS-2000-00084, ESH-ESS-2000-00125, ESH-ESS-2000-00172, ESH-ESS-200000210, ESH-ESS-2000-00248, ESH-ESS-2000-00276, ESH-ESS-2000-00310, ESH-ESS-2000-00346, ESH-ESS-2000-00366, and ESH-ESS-2000-00384. Westinghouse Savannah River Company, Aiken, South Carolina.

WSRC (Westinghouse Savannah River Company). 2001. Savannah River Site National Pollutant Discharge Elimination System Discharge Monitoring Reports. Individual reports for December 2000 through November 2001 were ESH-ESS-2001-00014, ESH-ESS-2001-00056, ESH-ESS-2001-00075, ESH-ESS2001-00116, ESH-EMS-01-080, ESH-EMS-01-0082, ESH-EMS-01-0084, ESH-EMS-01-0086, ESHEMS-01-0088, ESH-EMS-01-1224, ESH-EMS-01-1275 and ESH-EMS-01-1289. Westinghouse Savannah River Company, Aiken, South Carolina.

WSRC (Westinghouse Savannah River Company). 2002. Savannah River Site, NPDES Permit \#SC0000175, National Pollutant Discharge Elimination System Discharge Monitoring Reports. Individual reports for December 2001 through November 2002 were ESH-EMS-02-0527, ESH-EMS-02-0559, ESH-EMS-020578, ESH-EMS-02-0720, ESH-EMS-02-0773, ESH-EMS-02-1027, ESH-EMS-02-1170, ESH-EMS-021253, ESH-EMS-02-1455, ESH-EMS-02-1511, ESH-EMS-02-1608 and ESH-EMS-02-1717. Westinghouse Savannah River Company, Aiken, South Carolina.

WSRC (Westinghouse Savannah River Company). 2003. Savannah River Site, NPDES Permit \#SC0000175, National Pollutant Discharge Elimination System Discharge Monitoring Report for December 2002. ESHEMS-03-00184. Westinghouse Savannah River Company, Aiken, South Carolina.

Zillioux, E.J., D.B. Porcella, J.M. Benoit. 1993. Mercury Cycling and Effects in Freshwater Wetland Ecosystems. Environ. Toxicol. Chem. 12: 2245-2264. 
Appendix A. Savannah River Site NPDES Sampling Stations.

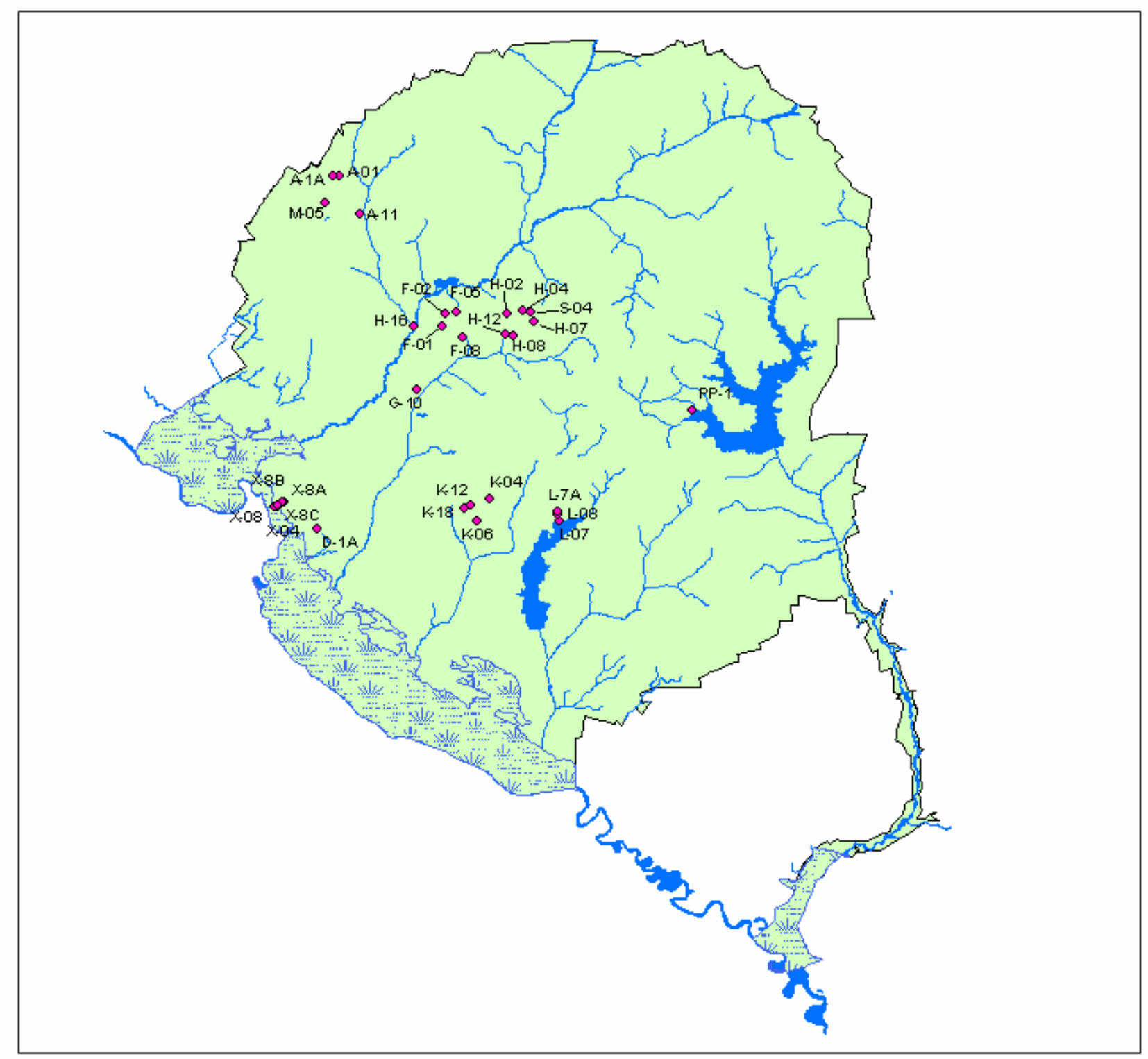


Appendix B. Savannah River and Stream Sampling Stations at the Savannah River Site.

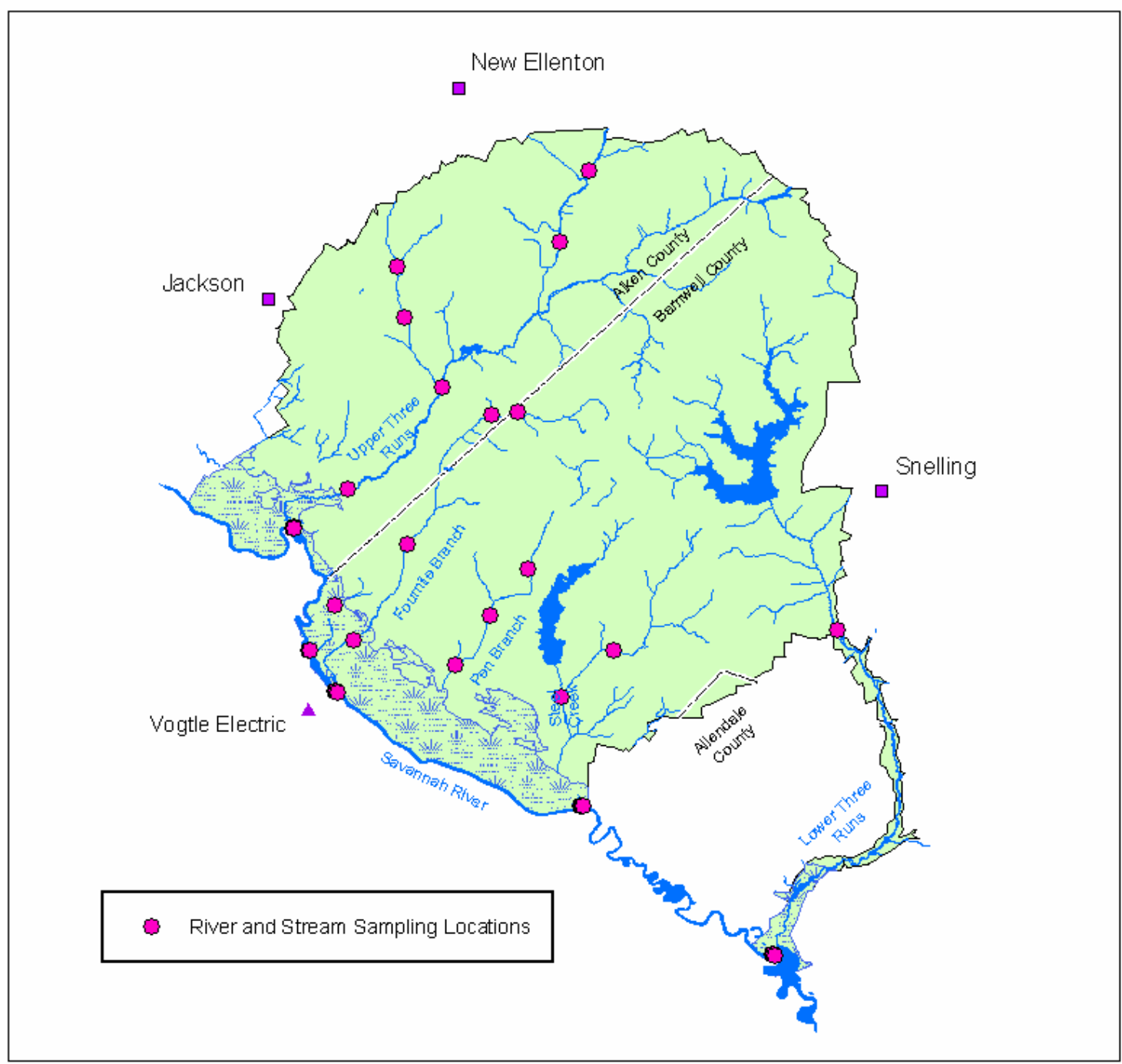


Appendix C. Total Mercury (ng/l) at Savannah River Site NPDES Outfalls.

\begin{tabular}{|c|c|c|c|c|c|c|c|c|c|c|}
\hline Outfall & 8/18/99 & 9/7/99 & 9/8/99 & 9/9/99 & 9/20/99 & $2 / 16 / 00$ & 2/17/00 & $2 / 23 / 00$ & $2 / 24 / 00$ & $8 / 30 / 00$ \\
\hline A-01 & 79.7 & - & - & - & - & - & - & - & - & 96.88 \\
\hline$A-1 A$ & - & 186.02 & 164.56 & 151.93 & - & - & - & - & - & - \\
\hline A-11 & - & - & - & - & - & 26.99 & - & - & - & 30.85 \\
\hline D-1A & - & - & - & - & - & - & 9.92 & - & - & 70.88 \\
\hline F-01 & - & - & - & - & - & - & - & - & - & 0.77 \\
\hline F-02 & - & - & - & - & - & - & - & - & - & 3.6 \\
\hline F-03 & - & - & - & - & - & - & - & - & - & dry \\
\hline F-05 & - & - & - & - & - & - & - & - & - & 33.6 \\
\hline F-08 & - & - & - & - & - & 3.35 & 1.15 & 3.26 & 1.71 & 1.55 \\
\hline G-10 & - & - & - & - & 35.64 & 9.72 & - & - & - & 6.9 \\
\hline H-02 & - & - & - & - & - & 7.27 & - & - & - & 8.52 \\
\hline $\mathrm{H}-04$ & - & - & - & - & - & - & - & - & - & dry \\
\hline H-07 & - & - & - & - & - & - & - & - & - & dry \\
\hline H-08 & - & - & - & - & - & 6.57 & - & - & - & 4.07 \\
\hline H-12 & - & - & - & - & - & 6.36 & 6.03 & - & - & - \\
\hline H-16 & - & - & - & - & - & - & - & - & - & - \\
\hline K-01 & - & - & - & - & - & - & - & - & - & - \\
\hline K-04 & - & - & - & - & - & - & - & - & - & 24.41 \\
\hline K-06 & - & - & - & - & - & 9.84 & - & - & - & 2.28 \\
\hline K-10 & - & - & - & - & - & - & - & - & - & - \\
\hline K-12 & - & - & - & - & - & - & 16.55 & - & - & - \\
\hline K-18 & - & - & - & - & - & 1.65 & - & - & - & 0.85 \\
\hline L-07 & - & - & - & - & - & 2.14 & - & - & - & 1.92 \\
\hline L-07A & - & - & - & - & - & - & 55.3 & - & - & - \\
\hline L-08 & - & - & - & - & - & 0.59 & - & - & - & 1.52 \\
\hline M-05 & - & - & - & - & - & - & - & - & - & - \\
\hline PP-1 & - & - & - & - & - & - & - & - & - & 0.31 \\
\hline S-04 & - & - & - & - & - & 5.83 & - & - & - & - \\
\hline X-04 & - & - & - & - & - & - & - & - & - & 15.26 \\
\hline X-08 & - & - & - & - & - & - & 151.6 & - & - & 101.06 \\
\hline $\mathrm{X}-08 \mathrm{~A}$ & - & - & - & - & - & - & 35.3 & - & - & 34.98 \\
\hline X-08B & - & - & - & - & - & - & - & - & - & - \\
\hline $\mathrm{X}-08 \mathrm{C}$ & - & - & - & - & - & - & - & - & - & - \\
\hline
\end{tabular}


Appendix C. Total Mercury (ng/l) at Savannah River Site NPDES Outfalls. (continued)

\begin{tabular}{|c|c|c|c|c|c|c|c|c|c|c|}
\hline Outfall & 10/19/00 & $12 / 11 / 00$ & $2 / 27 / 01$ & $2 / 28 / 01$ & 3/1/01 & $4 / 10 / 01$ & $8 / 7 / 01$ & 2/25/02 & $5 / 20 / 02$ & $9 / 4 / 02$ \\
\hline A-01 & 57.5 & - & 29.9 & - & - & - & 7.223 & - & 8.5 & - \\
\hline A-1A & 139 & - & 122 & - & - & - & 109.09 & - & 103 & - \\
\hline A-11 & 19 & - & 16.8 & - & - & - & 25.22 & 36.1 & 37.6 & 26.9 \\
\hline D-1A & 107 & - & 37.3 & - & - & - & - & - & 45.2 & - \\
\hline F-01 & 1.71 & - & 0.63 & - & - & - & 0.891 & - & 2.57 & - \\
\hline F-02 & 7.42 & - & 4.1 & - & - & - & 4.343 & - & 4.11 & - \\
\hline F-03 & - & - & - & - & - & - & - & - & - & - \\
\hline F-05 & 51.3 & - & 26.5 & - & - & - & 35.904 & - & 34.4 & - \\
\hline F-08 & 10.4 & - & 4.37 & - & - & - & 1.471 & - & 1.61 & - \\
\hline G-10 & 6.38 & - & 8.97 & - & - & - & 10.846 & - & 73.7 & - \\
\hline $\mathrm{H}-02$ & 6.81 & - & - & 6.8 & - & - & 6.592 & - & 6.38 & - \\
\hline $\mathrm{H}-04$ & - & - & - & 1.06 & - & - & 7.976 & - & 3.25 & - \\
\hline $\mathrm{H}-07$ & - & - & - & 7.36 & - & - & - & - & - & - \\
\hline H-08 & 3.91 & - & - & 1.07 & - & - & 2.515 & - & 2.71 & - \\
\hline $\mathrm{H}-12$ & 2.62 & - & - & 2.95 & - & - & 5.295 & - & 3.43 & - \\
\hline H-16 & - & 5.72 & - & - & - & 6.63 & - & - & - & - \\
\hline K-01 & - & - & - & - & - & - & - & - & - & - \\
\hline K-04 & 8.02 & - & - & - & 17.6 & - & - & - & - & - \\
\hline K-06 & - & - & - & 5.98 & - & - & - & - & - & - \\
\hline $\mathrm{K}-10$ & - & - & - & - & - & - & - & - & - & - \\
\hline $\mathrm{K}-12$ & 5.56 & - & - & 4.78 & - & - & 3.71 & - & 6.88 & - \\
\hline K-18 & 1.51 & - & - & 1.17 & - & - & 1.311 & - & 1.25 & - \\
\hline L-07 & 1.65 & - & - & - & 1.99 & - & 3.752 & 1.49 & 2.98 & 6.02 \\
\hline L-07A & 77.8 & - & - & 21.7 & - & - & 23.625 & - & 35.4 & - \\
\hline L-08 & - & - & - & - & 3.3 & - & - & - & - & - \\
\hline M-05 & 80.2 & - & 54.1 & - & - & - & 107.098 & 169 & 123 & 97.3 \\
\hline PP-1 & - & - & - & - & - & - & 28.492 & - & - & - \\
\hline S-04 & 1.22 & - & - & 5.8 & - & - & 8.892 & - & 1.37 & - \\
\hline$X-04$ & 190.9 & - & 15.7 & - & - & - & 184.143 & - & - & - \\
\hline X-08 & 168.7 & - & 121 & - & - & - & 128.966 & 254 & - & 436 \\
\hline X-08A & 52.1 & - & 18.8 & - & - & - & 27.092 & - & - & - \\
\hline X-08B & 94.2 & - & 121 & - & - & - & 36.764 & - & - & - \\
\hline X-08C & 323.5 & - & 319 & - & - & - & 526.181 & - & 604 & - \\
\hline
\end{tabular}


Appendix D. Total Mercury (ng/l) in Savannah River Site Streams.

\begin{tabular}{|c|c|c|c|c|c|c|c|}
\hline Location & 6/30/99 & $2 / 1 / 00$ & 3/13/00 & $5 / 18 / 00$ & 7/18/00 & $8 / 22 / 00$ & 9/14/00 \\
\hline Tims Branch at Steeds Pond & - & 5.83 & 8.45 & 1.99 & 3.81 & 1.73 & - \\
\hline Tims Branch at swamp & - & 4.29 & 5.62 & 8.00 & 9.54 & 3.41 & - \\
\hline Beaver Dam Creek at 400D & - & - & - & - & - & 3.87 & - \\
\hline Upper Three Runs at Tyler Bridge Road & 2.17 & 2.36 & 3.49 & 2.53 & 1.86 & 9.40 & - \\
\hline Upper Three Runs at Rt. 278 & - & - & - & - & - & 1.15 & - \\
\hline Upper Three Runs at Rd. C & - & - & - & - & - & 1.77 & - \\
\hline Upper Three Runs at Rt. 125 & - & - & 3.13 & 2.01 & 2.32 & 1.61 & - \\
\hline Fourmile Branch at swamp & 3.77 & 4.22 & 8.52 & 2.29 & 4.54 & 3.51 & - \\
\hline Fourmile Branch at Rd. 4 & - & - & - & - & - & 5.54 & - \\
\hline Fourmile Branch at Rd. C & - & 3.46 & 4.35 & 2.52 & 4.23 & 1.68 & 7.80 \\
\hline Fourmile Branch at Rt. 125 & - & 4.43 & 3.24 & 2.22 & 2.09 & 1.61 & - \\
\hline Pen Branch at Rd. B & - & - & - & - & - & 1.30 & - \\
\hline Pen Branch at Rt. 125 & - & - & - & - & - & 1.86 & - \\
\hline Pen Branch at Rd. 13.2 & 2.65 & 3.88 & 10.10 & 2.15 & 2.78 & 2.77 & - \\
\hline Meyers Branch at Rd. 9 & - & - & - & - & - & 1.60 & - \\
\hline Steel Creek at Rt. 125 & - & - & - & - & - & 2.50 & - \\
\hline Lower Three Runs at Patterson Mill Rd. & - & - & - & - & - & 2.53 & - \\
\hline Location & 10/19/00 & $2 / 20 / 01$ & $5 / 30 / 01$ & 8/23/01 & $2 / 25 / 02$ & $5 / 22 / 02$ & $9 / 4 / 02$ \\
\hline Tims Branch at Steeds Pond & 2.08 & 2.72 & 8.43 & 5.99 & - & - & - \\
\hline Tims Branch at swamp & 3.75 & 5.54 & 3.42 & 3.79 & - & - & - \\
\hline Beaver Dam Creek at 400D & 4.87 & - & - & - & 2.12 & 2.96 & 2.37 \\
\hline Upper Three Runs at Tyler Bridge Road & 4.31 & - & - & - & 1.37 & 4.84 & 2.68 \\
\hline Upper Three Runs at Rt. 278 & 1.63 & - & - & - & - & - & - \\
\hline Upper Three Runs at Rd. C & 1.09 & 1.38 & 8.86 & 1.54 & - & - & - \\
\hline Upper Three Runs at Rt. 125 & 15.71 & 1.57 & 6.40 & 1.35 & 1.61 & 2.15 & 2.26 \\
\hline Fourmile Branch at swamp & 5.21 & - & - & - & 2.75 & 2.67 & 2.03 \\
\hline Fourmile Branch at Rd. 4 & 11.05 & - & - & - & - & - & - \\
\hline Fourmile Branch at Rd. C & 3.08 & - & - & - & - & - & - \\
\hline Fourmile Branch at Rt. 125 & 1.76 & 3.64 & 5.96 & 0.95 & - & - & - \\
\hline Pen Branch at Rd. B & 1.10 & - & - & - & - & - & - \\
\hline Pen Branch at Rt. 125 & 1.65 & 1.85 & 4.48 & 2.13 & - & - & - \\
\hline Pen Branch at Rd. 13.2 & 2.62 & - & - & & 2.18 & 1.74 & 2.05 \\
\hline Meyers Branch at Rd. 9 & $-*$ & 1.47 & 8.40 & 2.01 & - & - & - \\
\hline Steel Creek at Rt. 125 & 3.35 & 1.93 & - & - & 2.57 & 4.27 & 2.66 \\
\hline Lower Three Runs at Patterson Mill Rd. & 1.92 & 1.82 & 4.60 & 2.54 & 2.46 & 5.13 & 13.30 \\
\hline
\end{tabular}

* Sample contained sediment/debris. 
Appendix E. Methylmercury (ng/l) in Savannah River Site Streams.

\begin{tabular}{|c|c|c|c|c|c|c|c|}
\hline Location & 6/24/99 & $2 / 1 / 00$ & $3 / 13 / 00$ & $5 / 18 / 00$ & $7 / 18 / 00$ & $8 / 22 / 00$ & $9 / 6 / 00$ \\
\hline Tims Branch at Steeds Pond & - & 0.024 & 0.088 & 0.140 & 0.195 & 0.244 & - \\
\hline Tims Branch at swamp & - & 0.159 & 1.700 & 0.999 & 2.601 & 0.536 & - \\
\hline Beaver Dam Creek at 400D & - & - & - & - & - & 0.133 & - \\
\hline Upper Three Runs at Tyler Bridge Road & 0.069 & 0.002 & 0.036 & 0.255 & 0.098 & 0.208 & - \\
\hline Upper Three Runs at Rt. 278 & - & - & - & - & - & 0.041 & - \\
\hline Upper Three Runs at Rd. C & - & - & - & - & - & 0.101 & - \\
\hline Upper Three Runs at Rt. 125 & - & - & 0.139 & 0.123 & 0.112 & 0.095 & - \\
\hline Fourmile Branch at swamp & 0.117 & 0.039 & 0.619 & 0.191 & 0.756 & 0.408 & - \\
\hline Fourmile Branch at Rd. 4 & - & - & - & - & - & 0.443 & - \\
\hline Fourmile Branch at Rd. C & - & 0.010 & 0.104 & 0.726 & 0.490 & 0.572 & 0.243 \\
\hline Fourmile Branch at Rt. 125 & - & 0.007 & 0.062 & 0.293 & 0.132 & 0.176 & - \\
\hline Pen Branch at Rd. B & - & - & - & - & - & 0.245 & - \\
\hline Pen Branch at Rt. 125 & - & - & - & - & - & 0.247 & - \\
\hline Pen Branch at Rt. 13.2 & 0.165 & 0.084 & 0.393 & 0.240 & 0.160 & 0.247 & - \\
\hline Meyers Branch at Rd. 9 & - & - & - & - & - & 0.124 & - \\
\hline Steel Creek at Rt. 1215 & - & - & - & - & - & 0.320 & - \\
\hline Lower Three Runs at Patterson Mill Rd. & - & - & - & - & - & 0.187 & - \\
\hline Location & 10/19/00 & $2 / 20 / 01$ & $5 / 30 / 01$ & $8 / 23 / 01$ & $2 / 25 / 02$ & $5 / 22 / 02$ & $9 / 4 / 02$ \\
\hline Tims Branch at Steeds Pond & 0.206 & 0.310 & 0.362 & 0.346 & - & - & - \\
\hline Tims Branch at swamp & 0.464 & 1.132 & 0.903 & 0.937 & - & - & - \\
\hline Beaver Dam Creek at 400D & 0.056 & - & - & - & 0.058 & 0.110 & 0.078 \\
\hline Upper Three Runs at Tyler Bridge Road & 0.154 & - & - & - & 0.180 & 0.131 & 0.101 \\
\hline Upper Three Runs at Rt. 278 & 0.050 & - & - & - & 0.136 & - & - \\
\hline Upper Three Runs at Rd. C & 0.066 & 0.135 & 0.256 & 0.120 & - & - & - \\
\hline Upper Three Runs at Rt. 125 & 0.077 & 0.163 & 0.233 & 0.124 & - & 0.122 & 0.109 \\
\hline Fourmile Branch at swamp & 1.500 & - & - & - & 0.189 & 0.113 & 0.069 \\
\hline Fourmile Branch at Rd. 4 & 0.228 & - & - & - & - & - & - \\
\hline Fourmile Branch at Rd. C & 0.351 & - & - & - & - & - & - \\
\hline Fourmile Branch at Rt. 125 & 0.063 & 0.088 & 0.289 & 0.102 & - & - & - \\
\hline Pen Branch at Rd. B & 0.155 & - & - & - & - & - & - \\
\hline Pen Branch at Rt. 125 & 0.114 & 0.195 & 0.438 & 0.217 & - & - & - \\
\hline Pen Branch at Rt. 13.2 & 0.101 & - & - & - & 0.121 & 0.208 & 0.128 \\
\hline Meyers Branch at Rd. 9 & 0.886 & 0.222 & 0.745 & 0.117 & - & - & - \\
\hline Steel Creek at Rt. 125 & 0.700 & 0.154 & & 0.325 & 0.116 & 0.257 & 0.148 \\
\hline Lower Three Runs at Patterson Mill Rd. & 0.099 & 0.198 & 0.372 & 0.165 & - & 0.205 & 0.675 \\
\hline
\end{tabular}


Appendix F. Total Mercury (ng/l) in the Savannah River.

\begin{tabular}{|c|c|c|c|c|c|c|c|c|c|c|c|c|c|c|}
\hline Location & 6/30/99 & $2 / 1 / 00$ & $5 / 18 / 00$ & $7 / 18 / 00$ & $7 / 26 / 00$ & $8 / 2 / 00$ & $8 / 22 / 00$ & $8 / 28 / 00$ & 10/19/00 & $11 / 7 / 00$ & $11 / 29 / 00$ & $12 / 5 / 00$ & $12 / 18 / 00$ & $12 / 18 / 00$ \\
\hline Above Upper Three Runs & - & - & - & - & - & - & - & 3.09 & 2.25 & 2.67 & 2.62 & 2.76 & 3.26 & 2.94 \\
\hline At Upper Three Runs & 4.12 & - & - & - & - & 7.36 & - & 1.82 & 1.25 & 1.27 & 2.12 & 1.04 & 1.57 & 1.41 \\
\hline Below Upper Three Runs & - & - & - & - & - & 3.45 & 2.23 & 3.01 & 2.28 & 2.5 & 2.3 & 2.56 & 1.41 & 2.87 \\
\hline Above Beaver Dam Creek & - & - & - & - & - & - & - & - & 2.29 & - & - & - & - & - \\
\hline At Beaver Dam Creek & - & - & - & - & - & - & - & 4.97 & 4 & 5.2 & 3.64 & 5.35 & 5.9 & 5.31 \\
\hline Below Beaver Dam Creek & - & - & - & - & - & - & - & - & 2.23 & - & 1.38 & 2.5 & 2.75 & 2.73 \\
\hline Above Fourmile Branch & - & - & - & - & - & - & - & - & - & - & - & - & - & - \\
\hline Below Fourmile Branch & - & - & - & - & - & - & - & 2.76 & 2.53 & 2.91 & 2.36 & 2.28 & 2.6 & 2.85 \\
\hline Above Steel Creek & - & - & - & - & - & - & - & - & - & - & - & - & - & - \\
\hline At Steel Creek & - & - & - & - & - & - & - & 3 & 2.1 & 1.93 & 1.91 & 0.62 & 1.35 & 1.47 \\
\hline Below Steel Creek & - & - & - & - & - & - & - & 2.99 & 2.74 & 2.64 & 2.18 & 2.1 & 4.29 & 3.68 \\
\hline Above Lower Three Runs & - & - & - & - & - & - & - & - & - & - & - & - & - & - \\
\hline At Lower Three Runs & - & - & - & - & - & 2.63 & - & 2.03 & 0.96 & 1.23 & 2.12 & 2.77 & 2.19 & 2.17 \\
\hline Below Lower Three Runs & - & - & - & - & - & 9.65 & - & 3.18 & 2.61 & 2.63 & 2.87 & 2.31 & 2.55 & 2.09 \\
\hline
\end{tabular}

Location

$\begin{array}{llllllllllllllll}12 / 18 / 00 & 2 / 20 / 01 & 4 / 17 / 01 & 4 / 17 / 01 & 4 / 17 / 01 & 5 / 30 / 01 & 7 / 24 / 01 & 8 / 15 / 01 & 8 / 23 / 01 & 9 / 20 / 01 & 2 / 26 / 02 & 5 / 23 / 02 & 9 / 3 / 02\end{array}$

Above Upper Three Runs

3.25

At Upper Three Runs

Below Upper Three Runs

Above Beaver Dam Creek

At Beaver Dam Creek

Below Beaver Dam Creek

3.25

2.614

Above Fourmile Branch

At Fourmile Branch

- $\quad 2.91$

2.614

Below Fourmile Branch

Above Steel Creek

At Steel Creek

Below Steel Creek

\begin{tabular}{cccccccccccccc}
- & 2.91 & 2.911 & 2.594 & 2.518 & 4.32 & 5.97 & 2.37 & 1.86 & 9.62 & 1.95 & 1.98 & 2.37 \\
- & - & - & - & - & - & - & 2.37 & - & - & - & - & - \\
5.9 & - & 3.944 & 4.013 & 4.365 & - & - & 3.96 & - & - & 4.01 & 3.85 & 2.86 \\
3.67 & - & 2.558 & 2.03 & 2.291 & - & - & 2.61 & - & - & 2.26 & 2.1 & 2.05 \\
- & - & - & - & - & - & - & 2.42 & - & - & - & - & - \\
1.97 & - & 5.841 & 5.709 & 7.191 & - & - & 4.69 & - & - & 3.98 & 1.78 & 2.88 \\
- & - & 2.374 & 1.929 & 2.168 & - & - & 2.5 & - & - & 2.13 & 3.7 & 2.02 \\
- & - & - & - & - & - & - & 2.88 & - & - & - & - & - & - \\
1.77 & - & 42.8 & 43.9 & 43.3 & - & - & 2.53 & - & - & 10.2 & 2.09 & 3.16 \\
4.14 & - & 2.762 & 2.222 & 2.958 & - & - & 5.85 & - & - & 1.79 & 2.43 & 2.22 \\
- & - & - & - & - & - & - & 2.85 & - & - & - & - & - \\
2 & - & 3.408 & 3.722 & 3.612 & - & - & 3.74 & - & - & 1.34 & 2.17 & 2.96 \\
2.83 & - & 3.011 & 3.779 & 2.905 & - & - & 2.74 & - & - & 3.35 & 2.44 & 1.94 \\
\hline
\end{tabular}


Appendix G. Methylmercury (ng/l) in the Savannah River.

\begin{tabular}{|c|c|c|c|c|c|c|c|c|c|c|c|c|c|}
\hline Location & 6/24/99 & $5 / 18 / 00$ & 7/18/00 & $8 / 2 / 00$ & $8 / 22 / 00$ & $8 / 28 / 00$ & 10/19/00 & $11 / 7 / 00$ & $11 / 29 / 00$ & $12 / 5 / 00$ & $12 / 18 / 00$ & $12 / 18 / 00$ & $12 / 18 / 00$ \\
\hline Above Upper Three Runs & & - & - & - & - & 0.114 & 0.036 & 0.073 & 0.06 & 0.041 & 0.047 & 0.042 & 0.044 \\
\hline At Upper Three Runs & 0.163 & - & - & 0.247 & - & 0.124 & 0.063 & 0.104 & 0.084 & 0.083 & 0.101 & 0.103 & - \\
\hline Below Upper Three Runs & - & - & - & 0.093 & 0.105 & 0.094 & 0.049 & 0.044 & 0.046 & 0.047 & 0.042 & 0.047 & - \\
\hline Above Beaver Dam Creek & - & - & - & - & - & - & 0.045 & - & - & - & - & - & - \\
\hline At Beaver Dam Creek & - & - & - & - & - & 0.158 & 0.089 & 0.145 & 0.074 & 0.088 & 0.1 & 0.092 & 0.116 \\
\hline Below Beaver Dam Creek & - & - & - & - & - & - & 0.05 & - & - & 0.044 & 0.041 & 0.045 & 0.046 \\
\hline Above Fourmile Branch & - & - & - & - & - & - & - & - & - & & & & \\
\hline At Fourmile Branch & 0.166 & 0.176 & 0.156 & - & - & 0.144 & 0.07 & 0.105 & 0.061 & 0.055 & 0.07 & 0.061 & 0.066 \\
\hline Below Fourmile Branch & - & - & - & - & - & 0.1 & 0.043 & 0.066 & 0.052 & 0.055 & 0.051 & 0.047 & - \\
\hline Above Steel Creek & - & - & - & - & - & - & - & - & - & - & - & - & - \\
\hline At Steel Creek & - & - & - & - & - & 0.129 & 0.154 & 0.22 & 0.096 & 0.072 & 0.138 & 0.145 & 0.121 \\
\hline Below Steel Creek & - & - & - & - & - & 0.127 & 0.04 & 0.064 & 0.246 & 0.047 & 0.041 & 0.051 & 0.04 \\
\hline Above Lower Three Runs & - & - & - & - & - & - & - & - & - & - & - & - & - \\
\hline At Lower Three Runs & - & - & - & 0.163 & - & 0.147 & 0.098 & 0.227 & 0.185 & 0.129 & 0.245 & 0.265 & 0.221 \\
\hline Below Lower Three Runs & - & - & - & 0.071 & - & 0.145 & 0.049 & 0.066 & 0.054 & 0.045 & 0.037 & 0.042 & 0.049 \\
\hline Location & $2 / 20 / 01$ & 4/17/01 & 4/17/01 & 4/17/01 & $5 / 30 / 01$ & $7 / 24 / 01$ & 8/15/01 & 8/23/01 & 9/20/01 & $2 / 26 / 02$ & $5 / 23 / 02$ & $9 / 3 / 02$ & \\
\hline Above Upper Three Runs & - & 0.124 & 0.121 & 0.115 & - & - & 0.108 & - & - & 0.081 & 0.141 & 0.088 & \\
\hline At Upper Three Runs & - & 0.357 & 0.331 & 0.309 & - & - & 0.192 & - & - & 0.13 & 0.11 & 0.317 & \\
\hline Below Upper Three Runs & 0.123 & 0.123 & 0.123 & 0.107 & 0.154 & 0.085 & 0.102 & 0.083 & 0.125 & 0.078 & 0.109 & 0.109 & \\
\hline Above Beaver Dam Creek & - & - & - & - & - & - & 0.094 & - & - & - & - & - & \\
\hline At Beaver Dam Creek & - & 0.154 & 0.16 & 0.158 & - & - & 0.106 & - & - & 0.093 & 0.099 & 0.097 & \\
\hline Below Beaver Dam Creek & - & 0.119 & 0.095 & 0.097 & - & - & 0.09 & - & - & 0.094 & 0.117 & 0.088 & \\
\hline Above Fourmile Branch & - & & & & - & - & 0.098 & - & - & - & - & - & \\
\hline At Fourmile Branch & - & 0.599 & 0.497 & 0.471 & - & - & 0.194 & - & - & 0.107 & 0.092 & 0.146 & \\
\hline Below Fourmile Branch & - & 0.415 & 0.106 & 0.092 & - & - & 0.092 & - & - & 0.127 & 0.104 & 0.077 & \\
\hline Above Steel Creek & - & & & & - & - & 0.094 & - & - & - & - & - & \\
\hline At Steel Creek & - & 7.266 & 7.187 & 7.542 & - & - & 0.303 & - & - & 0.934 & 0.222 & 0.103 & \\
\hline Below Steel Creek & - & 0.106 & 0.115 & 0.117 & - & - & 0.082 & - & - & 0.078 & 0.097 & 0.091 & \\
\hline Above Lower Three Runs & - & & & & - & - & 0.07 & - & - & - & - & - & \\
\hline At Lower Three Runs & - & 0.62 & 0.735 & 0.583 & - & - & 0.282 & - & - & 0.157 & 0.092 & 0.205 & \\
\hline Below Lower Three Runs & - & 0.181 & 0.191 & 0.164 & - & - & 0.084 & - & - & 0.07 & 0.107 & 0.088 & \\
\hline
\end{tabular}

